\title{
FIELD STUDIES OF THE POTENTIAL FOR WIND TRANSPORT OF PLUTONIUM-CONTAMINATED SOILS AT SITES IN AREAS 6 AND 11, NEVADA TEST SITE
}

Prepared by

Nicholas Lancaster

Robert Bamford

- Stephen Metzger

Submitted to

Nevada Operations Office

U.S. Department of Energy

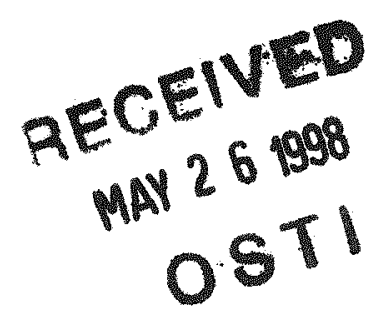

July 1995

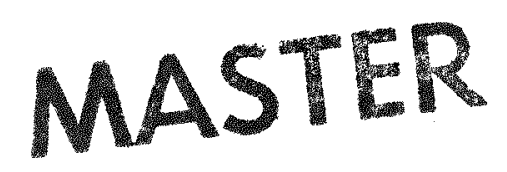

HH DISTRISUTION OF THS DOCWMEU! IS URMTIE 


\section{DISCLAIMER}

This report was prepared as an account of work sponsored by an agency of the United States Government. Neither the United States Government nor any agency Thereof, nor any of their employees, makes any warranty, express or implied, or assumes any legal liability or responsibility for the accuracy, completeness, or usefulness of any information, apparatus, product, or process disclosed, or represents that its use would not infringe privately owned rights. Reference herein to any specific commercial product, process, or service by trade name, trademark, manufacturer, or otherwise does not necessarily constitute or imply its endorsement, recommendation, or favoring by the United States Government or any agency thereof. The views and opinions of authors expressed herein do not necessarily state or reflect those of the United States Government or any agency thereof. 


\section{DISCLAIMER}

Portions of this document may be illegible in electronic image products. Images are produced from the best available original document. 
This report was prepared as an account of work sponsored by the United States Government. Neither the United States nor the United States Department of Energy, nor any of their employees, makes any warranty, express or implied, or assumes any legal liability or responsibility for the accuracy, completeness or usefulness of any information, apparatus, product or process disclosed, or represents that its use would not infringe privately owned rights. Reference herein to any specific commercial product, process, or service by trade name, mark, manufacturer, or otherwise, does not necessarily constitute or imply its endorsement, recommendation, or favoring by the United States Government or any agency thereof. The views and opinions of authors expressed herein do not necessarily state or reflect those of the United States Government or any agency thereof.

This report has been reproduced directly from the best available copy.

Available to DOE and DOE contractors from the Office of Scientific and Technical Information, P.O. Box 62, Oak Ridge, TN 37831; prices available from (615) 576-8401.

Available to the public from the National Technical Information Service. U.S. Department of Commerce, 5285 Port Royal Rd., Springfield, VA 22161. 


\title{
FIELD STUDIES OF THE POTENTIAL FOR WIND TRANSPORT OF PLUTONIUM-CONTAMINATED SOILS AT SITES IN AREAS 6 AND 11, NEVADA TEST SITE
}

\author{
Prepared by \\ Nicholas Lancaster \\ Robert Bamford \\ Stephen Metzger \\ Quaternary Sciences Center \\ Desert Research Institute \\ University and Community College System of Nevada
}

Publication No. 45136

Submitted to

Nevada Operations Office

U.S. Department of Energy

Las Vegas, Nevada

July 1995

The work upon which this report is based was supported by the U.S. Department of Energy under Contract \#DE-AC08-90NV10845. 


\begin{abstract}
This report describes and documents a series of field experiments carried out in Areas 6 and 11 of the Nevada Test Site in June and July 1994 to determine parameters of boundary layer winds, surface characteristics, and vegetation cover that can be used to predict dust emissions from the affected sites.

Aerodynamic roughness of natural sites is determined largely by the lateral cover of the larger and more permanent roughness elements (shrubs). These provide a complete protection of the surface from wind erosion.

Studies using a field-portable wind tunnel demonstrated that natural surfaces in the investigated areas of the Nevada Test Site are stable except at very high wind speeds (probably higher than normally occur, except perhaps in dust devils). However, disturbance of silty-clay surfaces by excavation devices and vehicles reduces the entrainment threshold by approximately $50 \%$ and makes these areas potentially very susceptible to wind erosion and transport of sediments.
\end{abstract}




\section{CONTENTS}

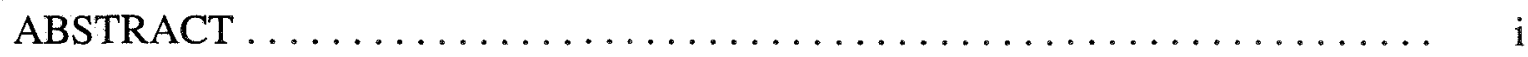

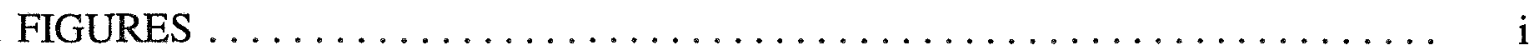

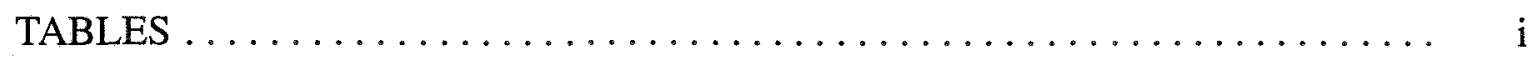

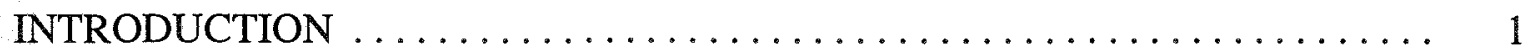

SCIENTIFIC RATIONALE $\ldots \ldots \ldots \ldots \ldots \ldots \ldots \ldots \ldots \ldots \ldots \ldots \ldots \ldots \ldots \ldots \ldots$

Controls of Entrainment Thresholds $\ldots \ldots \ldots \ldots \ldots \ldots \ldots \ldots \ldots \ldots, 4$

Controls of Aerodynamic Roughness Length $\ldots \ldots \ldots \ldots \ldots \ldots \ldots \ldots$

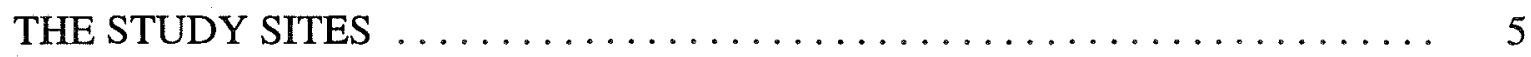

Descriptions of the Study Sites $\ldots \ldots \ldots \ldots \ldots \ldots \ldots \ldots \ldots \ldots \ldots \ldots$

RELATIONS BETWEEN BOUNDARY LAYER WINDS AND

VEGETATION COVER $\ldots \ldots \ldots \ldots \ldots \ldots \ldots \ldots \ldots \ldots \ldots, 10$

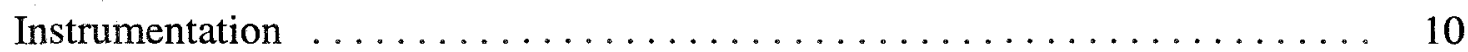

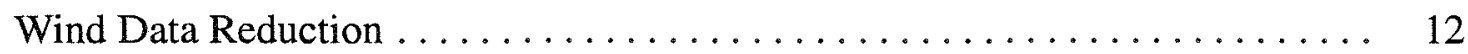

Results .................................... 13

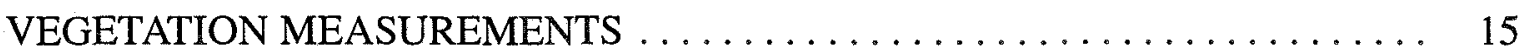

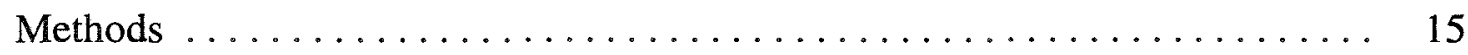

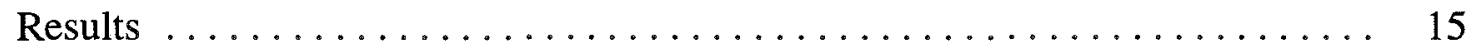

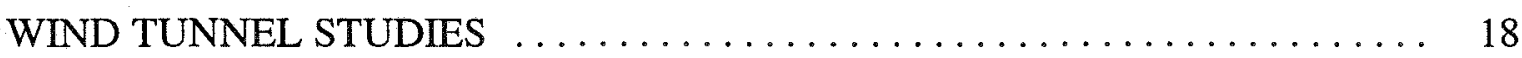

Description of the Wind Tunnel and its Operation $\ldots \ldots \ldots \ldots \ldots \ldots \ldots . \ldots$

Data Reduction ..................................... 19

Measurement of Surface Characteristics $\ldots \ldots \ldots \ldots \ldots \ldots \ldots \ldots \ldots 20$

Wind Tunnel Results .............................. 20

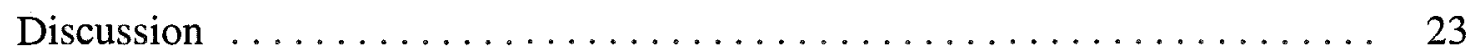

RELATIONS BETWEEN ENTRAINMENT THRESHOLDS AND

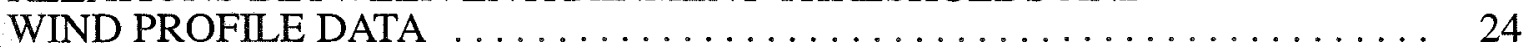

CONCLUSIONS AND MANAGEMENT IMPLICATIONS $\ldots \ldots \ldots \ldots \ldots \ldots 25$

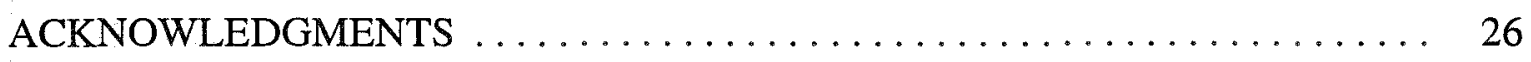

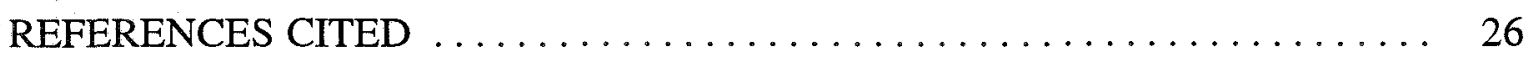

APPENDIX 1. WIND PROFILE DATA $\ldots \ldots \ldots \ldots \ldots \ldots \ldots \ldots \ldots, 28$

APPENDIX 2. LATERAL COVER MEASUREMENTS ............. 38

APPENDIX 3. WIND TUNNEL PROFILE DATA $\ldots \ldots \ldots \ldots \ldots \ldots \ldots, 43$

APPENDIX 4. WIND TUNNEL PROFILE PARAMETER DATA $\ldots \ldots \ldots \ldots 61$ 


\section{FIGURES}

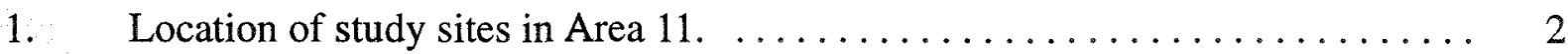

2a. Gate 2 Site: general view of surface and its vegetation cover. $\ldots \ldots \ldots \ldots .3$

2b. Gate 2 Site: close-up view of surface. $\ldots \ldots \ldots \ldots \ldots \ldots \ldots \ldots \ldots \ldots$

3a. Bedrock Site: general view of surface and its vegetation cover. $\ldots \ldots \ldots \ldots 7$

3b. Bedrock Site: close-up view of surface. $\ldots \ldots \ldots \ldots \ldots \ldots \ldots \ldots \ldots \ldots$

4a. Joshua Site: general view of surface and its vegetation cover. $\ldots \ldots \ldots \ldots .8$

4b. Joshua Site: close-up view of surface. $\ldots \ldots \ldots \ldots \ldots \ldots \ldots \ldots \ldots$

5a. Area 6 Site: general view of surface and its vegetation cover. .......... 9

5b. Area 6 Site: close-up view of surface. . . . . . . . . . . . . .

6a. Rotomill Site: dry surface after passage of excavation device. .......... 11

6b. Rotomill Site: surface of swath cut by excavation device with foam added to water supply. $\ldots \ldots \ldots \ldots \ldots \ldots \ldots \ldots \ldots \ldots \ldots \ldots \ldots \ldots \ldots \ldots \ldots, 11$

7. 10 -m anemometer mast at Area 6 site. . . . . . . . . . . . . . . . 12

8. Representative wind profiles for investigated sites. . . . . . . . . . . . 14

9. Relations between aerodynamic roughness and shrub lateral cover (normalized to total lateral cover for each site) . . . . . . . . . . . . . 18

10. The wind tunnel as deployed at the Area 6 site . . . . . . . . . . . . . . 19

11. Histograms of penetrometer values at natural and disturbed sites. . . . . . 21

12. Representative wind tunnel profiles for natural sites. .............. 22

13. Changes in threshold wind shear velocity with time for disturbed sites. ..... 24

14. Percentage of the time wind shear velocities, as measured at the Area $610-\mathrm{m}$ mast, exceeded selected values during the period

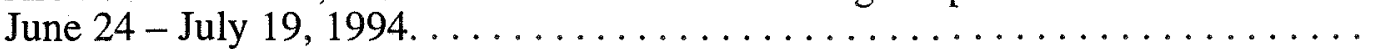




\section{TABLES}

1. Wind profile parameters at investigated sites, $1994 \ldots \ldots \ldots \ldots \ldots \ldots$

2. Comparison of aerodynamic roughness estimates (m) between 1993 and 1994. . 16

3. Comparison between 1993 and 1994 lateral cover at Gate sites. . . . . . . . 16

4. Comparison between 1993 and 1994 lateral cover at Bedrock sites. . . . . . 17

5. Comparison between 1993 and 1994 lateral cover at Josh sites. . . . . . . . 17

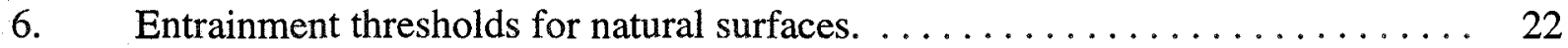

7. Entrainment thresholds for disturbed surfaces. ............... 23 


\section{INTRODUCTION}

This report describes and documents a series of field experiments carried out in Areas 6 and 11 of the Nevada Test Site in June and July 1994 as a continuation of boundary layer wind and vegetation cover studies conducted in Area 11 in summer 1993 (Lancaster and Bamford, 1994). The goal of the field experiments was to determine parameters of boundary layer winds, surface characteristics, and vegetation cover that can be used to predict dust emissions from the affected sites, and to enable use of expressions such as those of Gillette and Passi (1988) to estimate dust flux from meteorological observations of wind speeds. They will also guide environmental restoration activities and management practices by identifying potential problems for surface stabilization and soil removal activities. These studies continue the work of Shinn and Homan (1987) and Shinn et al. (1989), who demonstrated the significant impact of environmental restoration activities on the wind erosion potential of Area 11 and 18 soils. The investigations will also provide input to studies of the risks to offsite communities and worker safety during remediation. The current target site is located in Area 11 (Plutonium Valley) of the Nevada Test Site (NTS) where a total area of approximately 300 acres of plutonium-contaminated soil has been identified. The models and procedures developed in this project will, however, be applicable to other areas of heavy metal contamination on the NTS and elsewhere.

The specific aim of the experiments was twofold: (1) to understand relations between near-surface, boundary layer wind profiles and vegetation cover to determine the protection offered to natural surfaces by vegetation cover (these studies will also be valuable in determining the amount and size of planted vegetation required for protection of surfaces following environmental restoration activities) and (2) to determine the wind speeds necessary to entrain surface particles from natural and disturbed surfaces in the study areas. These studies provide information on the degree to which entrainment threshold wind speeds will be changed following surface disturbance in conjunction with environmental restoration activities and suggest the requirements for surface stabilization procedures. Field measurements of wind profiles were conducted at four locations in Plutonium Valley and adjacent areas of Yucca Flat (Figure 1) from June 21 to July 18 using one 6-m and one 10-m-high mast. Particle movement measurements were generated through the use of a portable wind tunnel laid directly on the desert surface at the same four locations.

\section{SCIENTIFIC RATIONALE}

Transport of sediment by the wind results from the drag or shear stress imparted by the wind to the surface. Under conditions of neutral atmospheric stability, the velocity profile for aerodynamically rough surfaces is characterized by the Prandtl-Von Karman equation

$$
u / u_{*}=1 / \mathrm{k} \ln \left(z-d / z_{o}\right)
$$

where $u$ is the wind speed at height $z, \mathrm{~d}$ is the zero-plane displacement, and $z_{o}$ is the aerodynamic roughness length. The shear velocity $(u *)$ is proportional to the slope of the wind velocity profile when plotted on a logarithmic height scale and is related to the shear stress $\tau$ at the bed and the air density (Q) by

$$
u_{*}=(\tau / \mathrm{\varrho})^{1 / 2}
$$




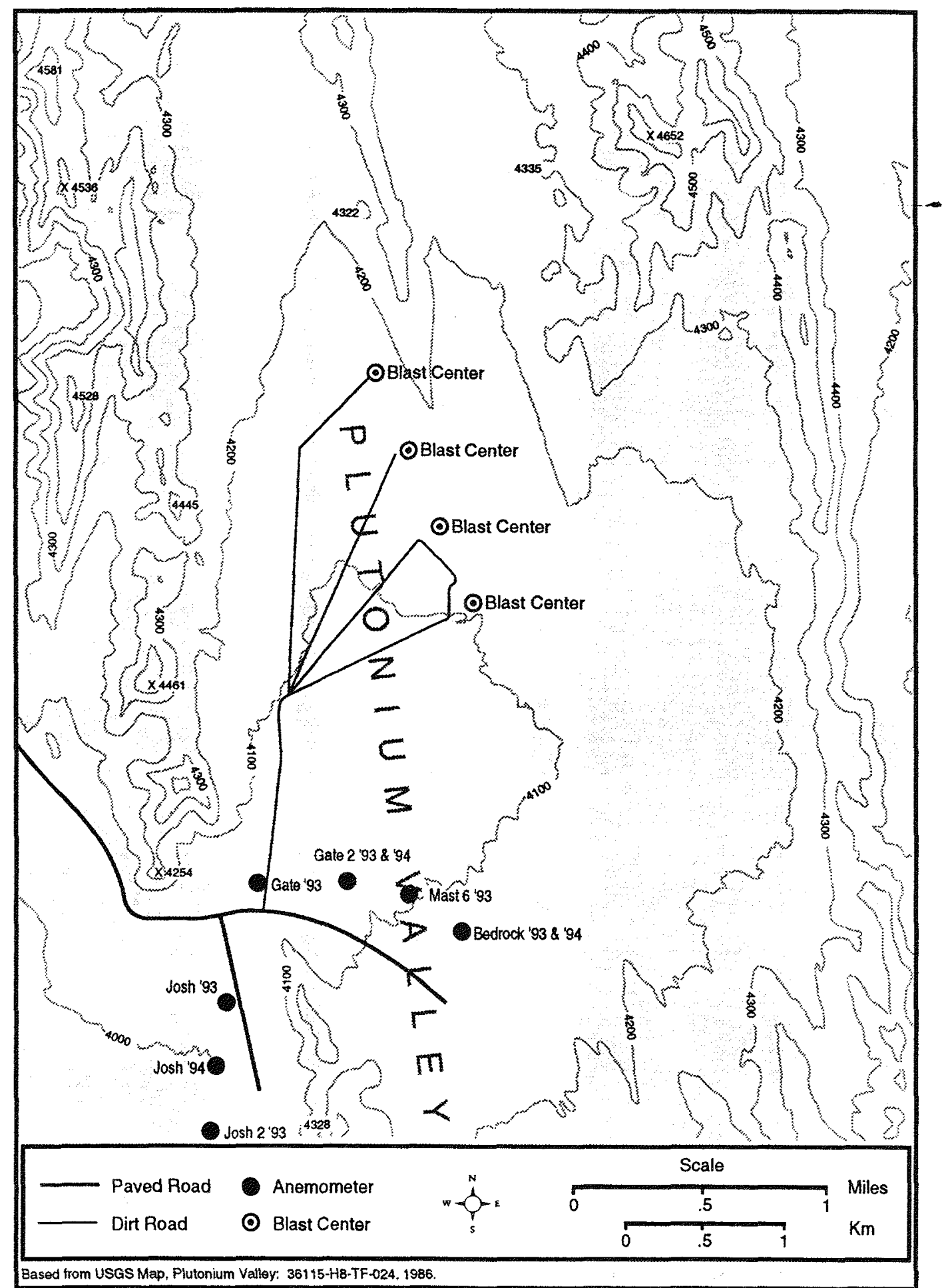

Figure 1. Location of study sites in Area 11. 
Particles will be moved by the wind when the fluid forces (lift, drag, moment) exceed the effects of the weight of the particle and cohesion between adjacent particles. The drag and lift forces as well as the resultant moment are caused by the fluid flow around and over the exposed particles. The weight and cohesive forces are related to physical properties of the surface particles including their size, density, mineralogy, shape, packing, moisture content, and the presence or absence of bonding agents such as soluble salts.

As drag and lift on the particle increase, there is a critical value of wind shear velocity when grain movement is initiated. This is the fluid threshold shear velocity or $u_{*}$ (Bagnold, 1941):

$$
u_{*_{t}}=A \sqrt{\frac{\varrho_{p}-\varrho_{a}}{\varrho_{a}} g d}
$$

where $\mathrm{A}$ is an empirical coefficient dependent on grain characteristics (approximately 0.1 for sand sized particles) and $\varrho_{a}$ is atmospheric density and $\varrho_{p}$ is particle density.

Although fluid threshold can be closely defined for a uniform sediment size greater than approximately $100 \mu \mathrm{m}$, this is not the case for most natural sediments and soils because they usually contain a range of grain sizes and shapes which vary in grain density and packing. As a result, entrainment thresholds should be considered as ranges that are a function of the size, shape, sorting and packing of the surface sediments.

\section{Controls of Entrainment Thresholds}

Several major environmental controls on entrainment thresholds can be identified. Surface moisture content controls both the entrainment and flux of sediment by the wind. Capillary forces developed at inter-particle contacts increase the cohesion and thus the threshold shear velocity. Gravimetric moisture contents of approximately $0.6 \%$ can more than double the threshold velocity of medium-sized sands. Above approximately 5\% gravimetric moisture content, sand-sized material is inherently resistant to entrainment by most natural winds (Belly, 1964).

Particles at the surface may be bound together by silt and clay, organic matter, or precipitated soluble salts to produce erosion-resistant structural units or more continuous surface crusts (Chepil and Woodruff, 1963; Nickling, 1984). Even low concentrations of soluble salts (especially sodium chloride) can significantly increase threshold velocity by the formation of cement-like bonds between individual particles (Nickling and Ecclestone, 1981). Surface crusts formed by raindrop impact, algae and fungi, or precipitation of soluble salts also increase the threshold velocity (Gillette et al., 1982).

The presence of vegetation, gravel lag deposits or other non-erodible roughness elements is important to both the entrainment and transport of material by the wind. When the wind blows over a smooth unobstructed surface, the shear stress is imparted more or less uniformly across the entire surface, but when non-erodible roughness elements are present, a proportion of the shear stress is absorbed by the roughness elements protecting the underlying erodible surface. The degree of protection is a function of their size, geometry, and spacing (Lyles et al., 1974; Marshall, 1971; 
Musick and Gillette, 1990; Raupach et al., 1993). Low densities of roughness elements tend to reduce the threshold velocity of the surface and cause increased erosion around the elements because of the development and shedding of eddies (Logie, 1982). By contrast, higher densities of roughness elements tend to increase the threshold velocity of the surface.

\section{Controls on Aerodynamic Roughness Length}

Aerodynamic roughness length is a complex function of roughness element geometry, with the height and spacing of the roughness elements generally considered to be a major factor (Garratt, 1992; Wolfe and Nickling, 1993). Several measures of roughness element geometry have been proposed. These include the roughness concentration or frontal area index (Wooding et al., 1973)

$$
\lambda=\mathrm{A}_{\mathrm{r}} / \mathrm{S}
$$

where $A_{r}$ is the frontal or silhouette area of the roughness elements and $S$ is the area of a flat surface covered by each element. This was modified by Raupach et al. (1993)

$$
\lambda=\mathrm{nhw} / \mathrm{S}
$$

where $h$ and $w$ are the height and width of the roughness elements, and $n$ is the number of roughness elements in a given area S. For vegetated surfaces, the roughness density can be described by the lateral cover of plants (Marshall, 1971; Musick and Gillette, 1990). Lateral cover is defined as the ratio between silhouette area (the cross section of the plant that the wind "sees") and total floor area:

$$
\mathrm{L}_{\mathrm{c}}=\mathrm{DS}
$$

where D is canopy population density (number of individuals per unit area) and $S$ is mean frontal-silhouette area (height $x$ diameter) per canopy.

Vegetation cover affects the entrainment threshold via increasing the aerodynamic roughness of the surface $\left(\mathrm{z}_{\mathrm{o}}\right)$. This will affect the threshold wind shear velocity for transport $\left(\mathrm{u}_{*_{\mathrm{t}}}\right)$, following Greeley et al. (1974):

$$
u_{* t}=\frac{0.139 \varrho g d}{\varrho\left(1+0.776\left(\ln \left(1+d / z_{0}\right)\right)^{2}\right)}
$$

where $\mathrm{d}=$ the diameter of the grains in transport. This expression was developed for unvegetated rough (e.g., rocky) surfaces and its application to vegetated surfaces is unknown. The effect on sediment flux can be predicted via the equation of White (1979):

$$
\mathrm{q}=2.61 \mathrm{u} *^{3}(1=\mathrm{u} * \mathrm{t} / \mathrm{u} *)\left(1+\mathrm{u} * \mathrm{t}^{2} / \mathrm{u} *^{2}\right) \mathrm{Q} / \mathrm{g}
$$




\section{THE STUDY SITES}

The sites chosen for study in the 1994 field season had two types of surfaces: natural and disturbed. Four locations with natural surfaces were selected for studies of boundary layer winds, vegetation cover characteristics and entrainment threshold wind tunnel tests (Figure 1). The disturbed surface locations were selected to examine the influence of vehicles and excavation devices on entrainment thresholds. The natural surfaces selected were designed to provide data for a range of desert pavements, soil particle compositions, and vegetation types and densities considered to be representative of the contaminated areas of Plutonium Valley. An anemometer mast (either $10 \mathrm{~m}$ or $6 \mathrm{~m}$ height ) was installed near the wind tunnel tests in each of these locations.

\section{Descriptions of the Study Sites}

\section{Natural Sites}

1. Gate 2 was located adjacent to the Desert Research Institute's Energy and Environmental Engineering Center's dust samplers near the gate to Plutonium Valley. This area (Figure 2a) lies within a small gap along a north-south ridge of moderate $(60 \mathrm{~m})$ relief. Local topography consisted of two or three 50-cm-deep washes running in a south to north direction. Local slope was to the north at 2 to $3^{\circ}$. The ground surface consists of a poorly developed desert pavement consisting of 2 - to $3-\mathrm{cm}$ angular platy gravel-sized clasts and scattered 10- to 15-cm-diameter small boulders (Figure 2b). All clasts were composed of welded tuffs.

2. Bedrock was located close to the National Weather Service meteorological station at the Tweezer facility. The area lies approximately $100 \mathrm{~m}$ east of the north-south ridge described above. The site (Figure 3a) consists of a well-developed gravel to small cobble desert pavement surface (Figure $3 \mathrm{~b}$ ) with a slope of $2^{\circ}$ to the northeast. Some Joshua trees were scattered throughout the area.

3. Joshua 3 (referred to hereafter as "Joshua") was located on the northern edge of Yucca Flat (Figure 4a) in an area several hundred meters west of the ridge and gap described at the Gate location. This location was intermediate between the "Josh" and "Josh 2" locations of the 1993 field season. Its surface consists of flat angular gravel desert pavement that covers a cumulic silty clay soil, with rare $50-\mathrm{cm}$ boulders present on the surface (Figure $4 \mathrm{~b}$ ). The site has a surface slope of 4 to $5^{\circ}$ to the southwest and widely scattered Joshua trees. Several shallow washes cross the area north of the site and head southwest toward Yucca Flat.

4. Area 6 was located on the level ground of the basin floor, north of Yucca Flat (Figure 5a), adjacent to the Habitat Restoration Test Site and the location of the excavation device tests (see below). Surface composition was primarily silt and clay, interspersed with 0.25 - to $1.5-\mathrm{cm}$ pebbles and cyanobacteria aggregates, bonded into a crust overlain by 10- to 15 -cm-diameter polygonal mud desiccation cracks (Figure $5 \mathrm{~b}$ ). On numerous occasions dust devil vortices formed over this surface and raised well-defined dust columns many hundreds of meters high into the atmosphere. 


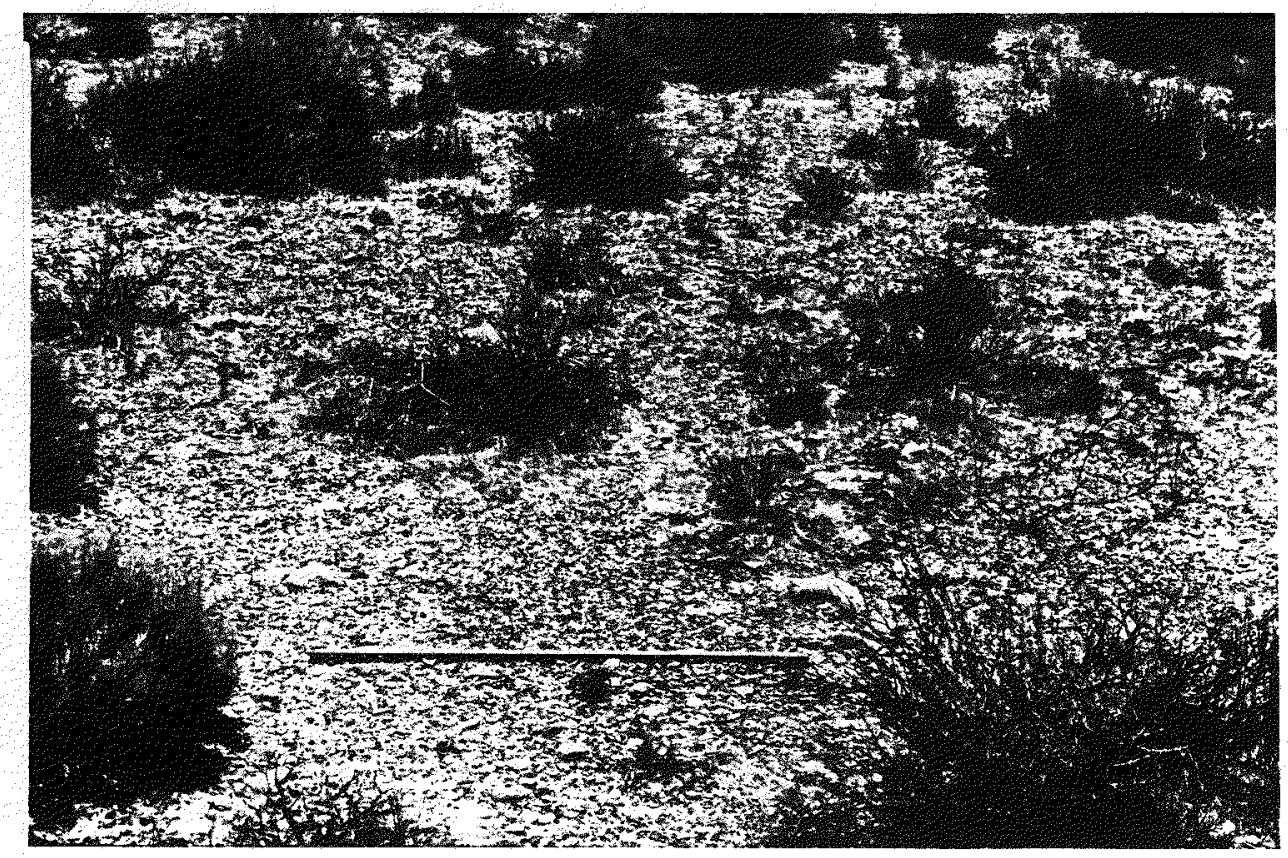

Figure 2a. Gate 2 Site: general view of surface and its vegetation cover. Scale bar is $1 \mathrm{~m}$ long.

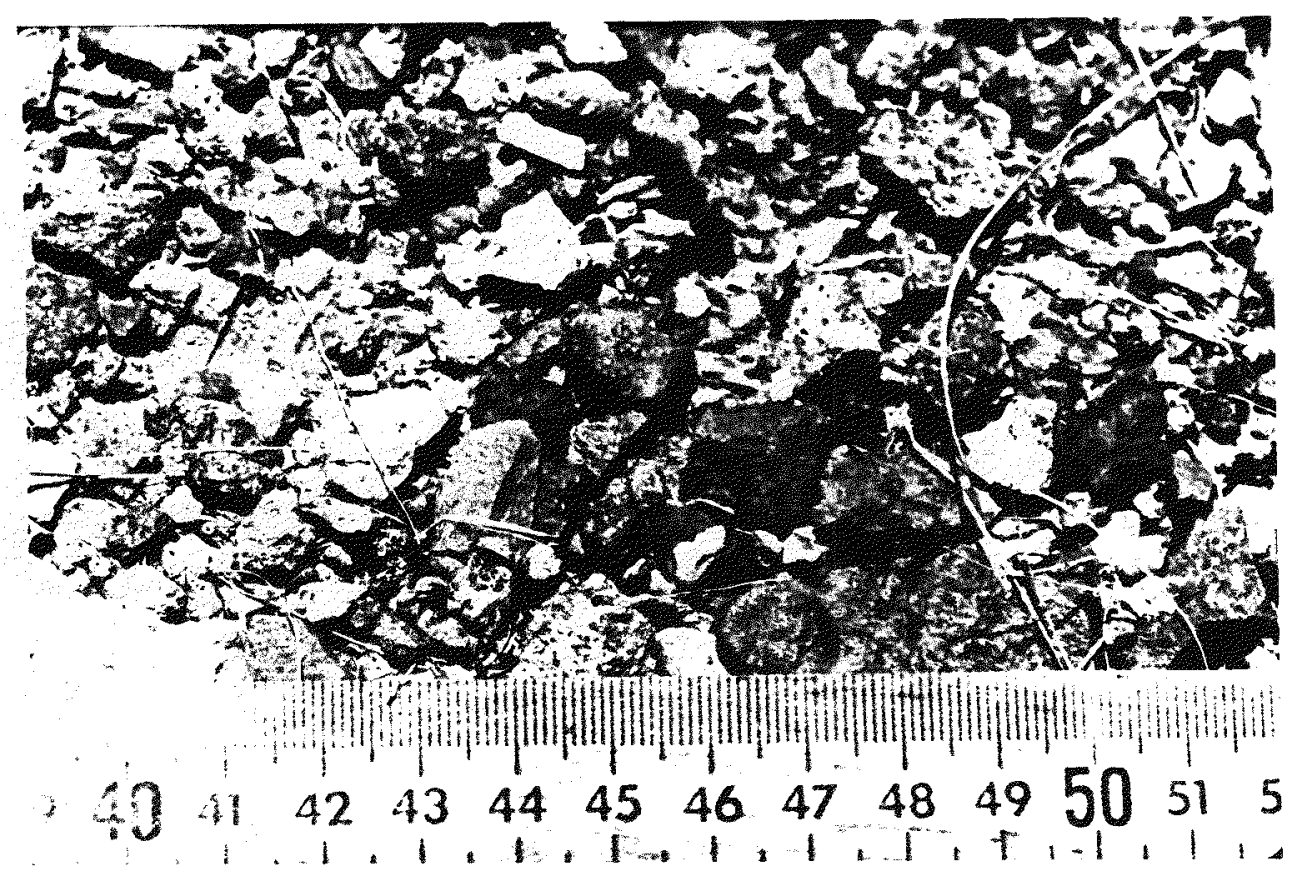

Figure $2 b$. Gate 2 Site: close-up view of surface. Scale is in $\mathrm{cm}$. 


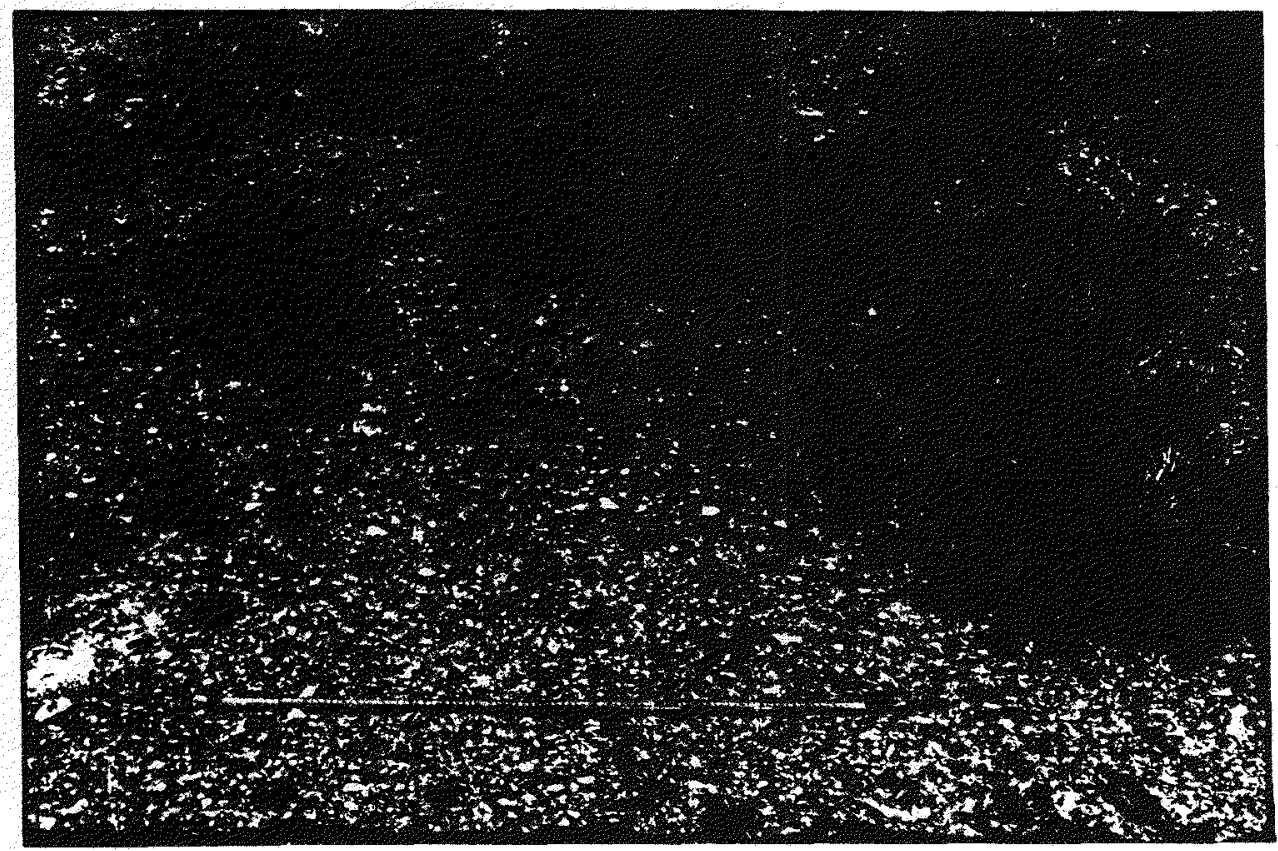

Figure 3a. Bedrock Site: general view of surface and its vegetation cover. Scale bar is $1 \mathrm{~m}$ long.

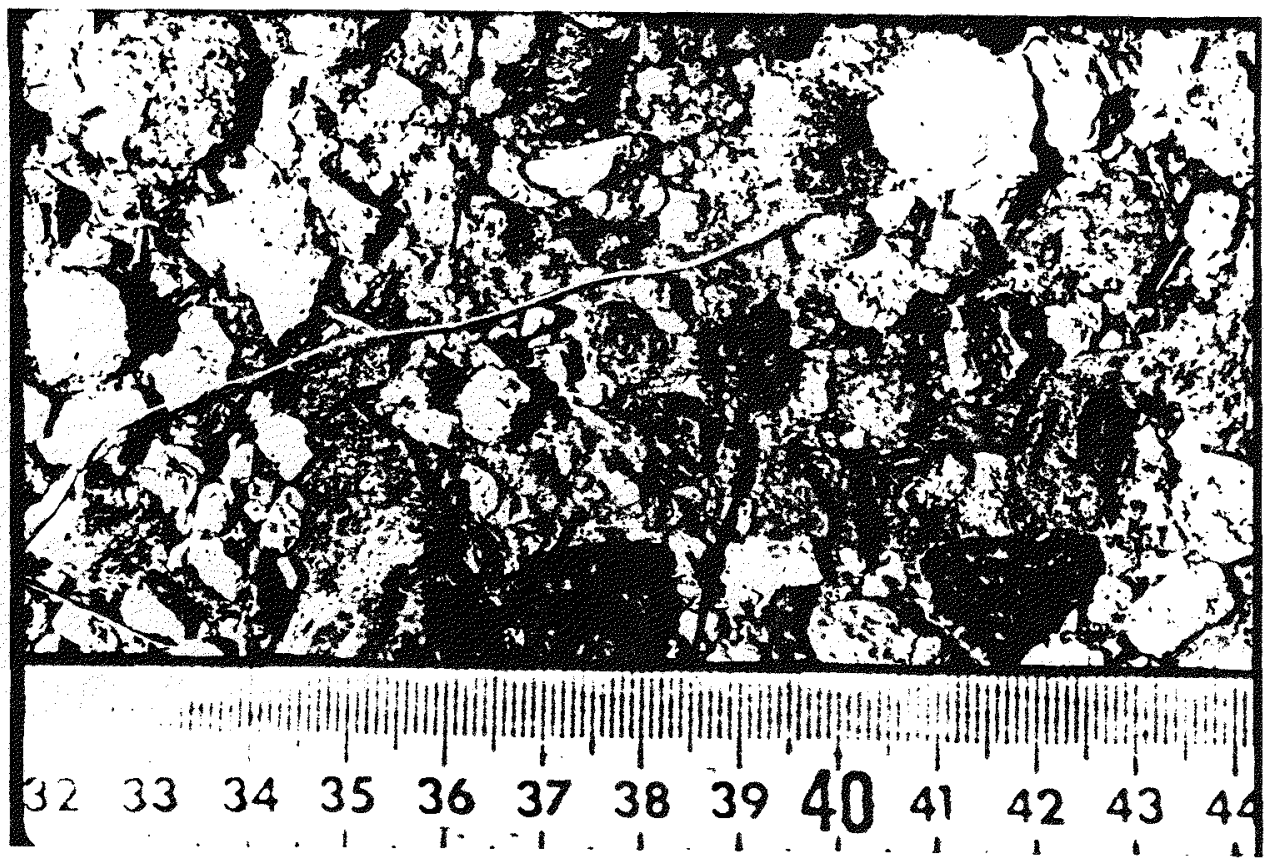

Figure 3b. Bedrock Site: close-up view of surface. Scale is in $\mathrm{cm}$. 


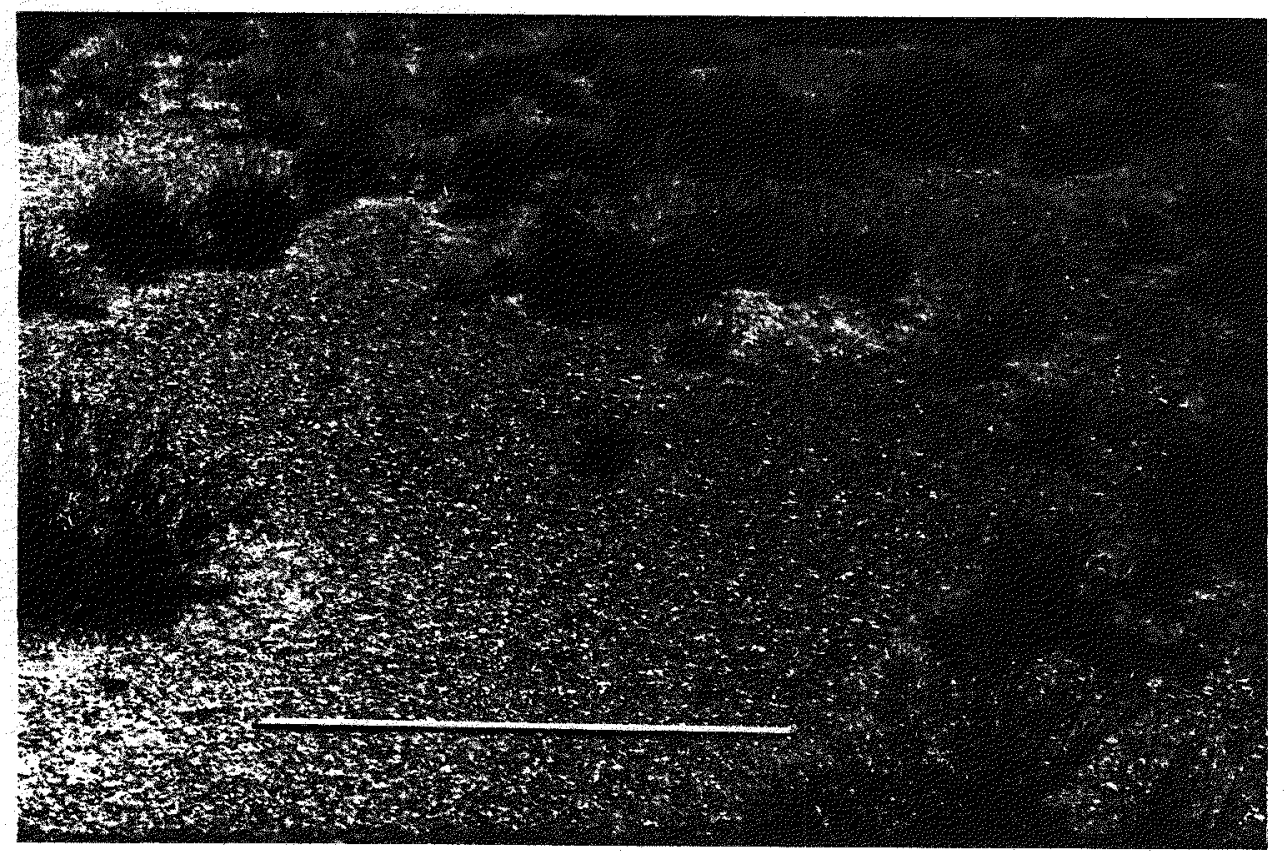

Figure 4a. Joshua Site: general view of surface and its vegetation cover. Scale bar is $1 \mathrm{~m}$ long.

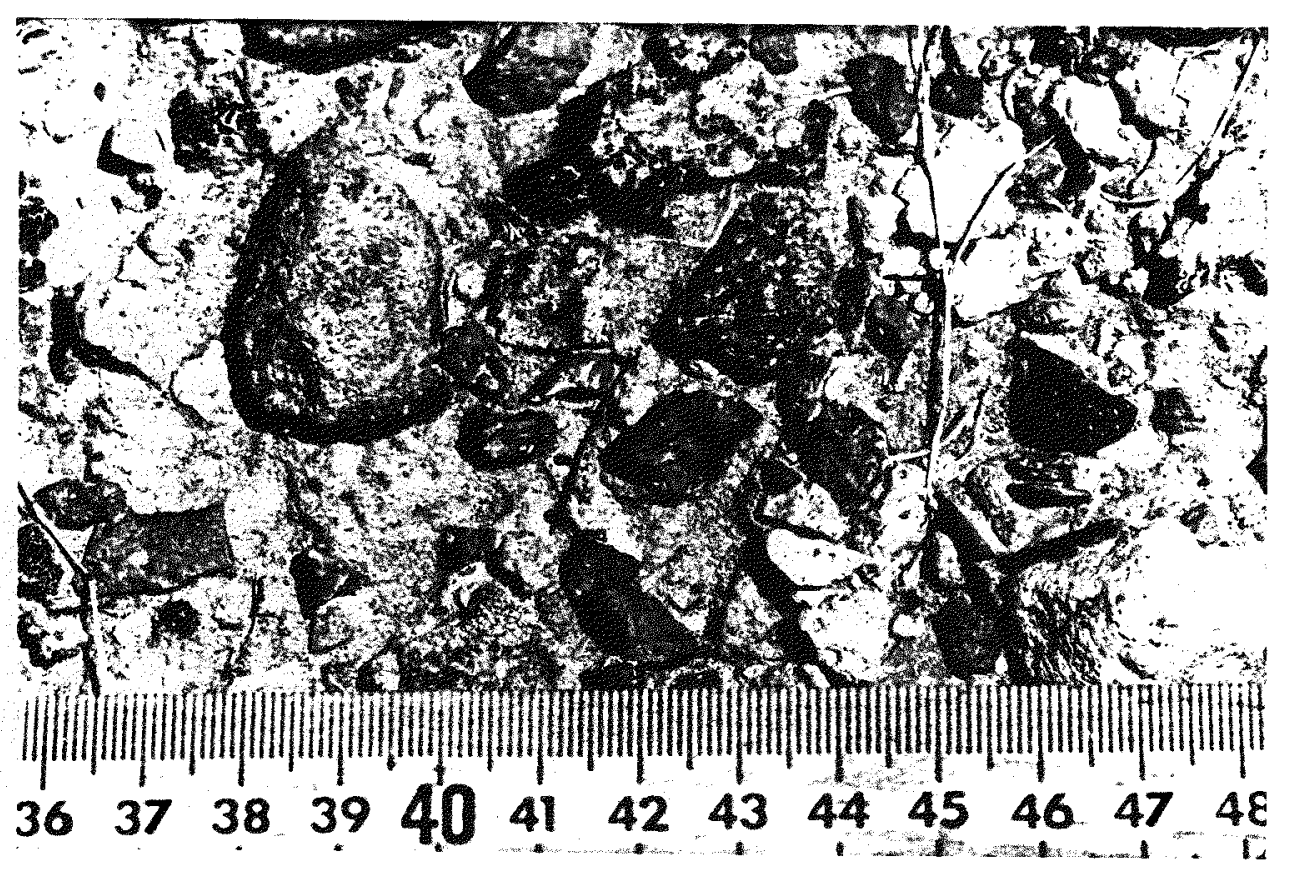

Figure $4 b$. Joshua Site: close-up view of surface. Scale is in $\mathrm{cm}$. 


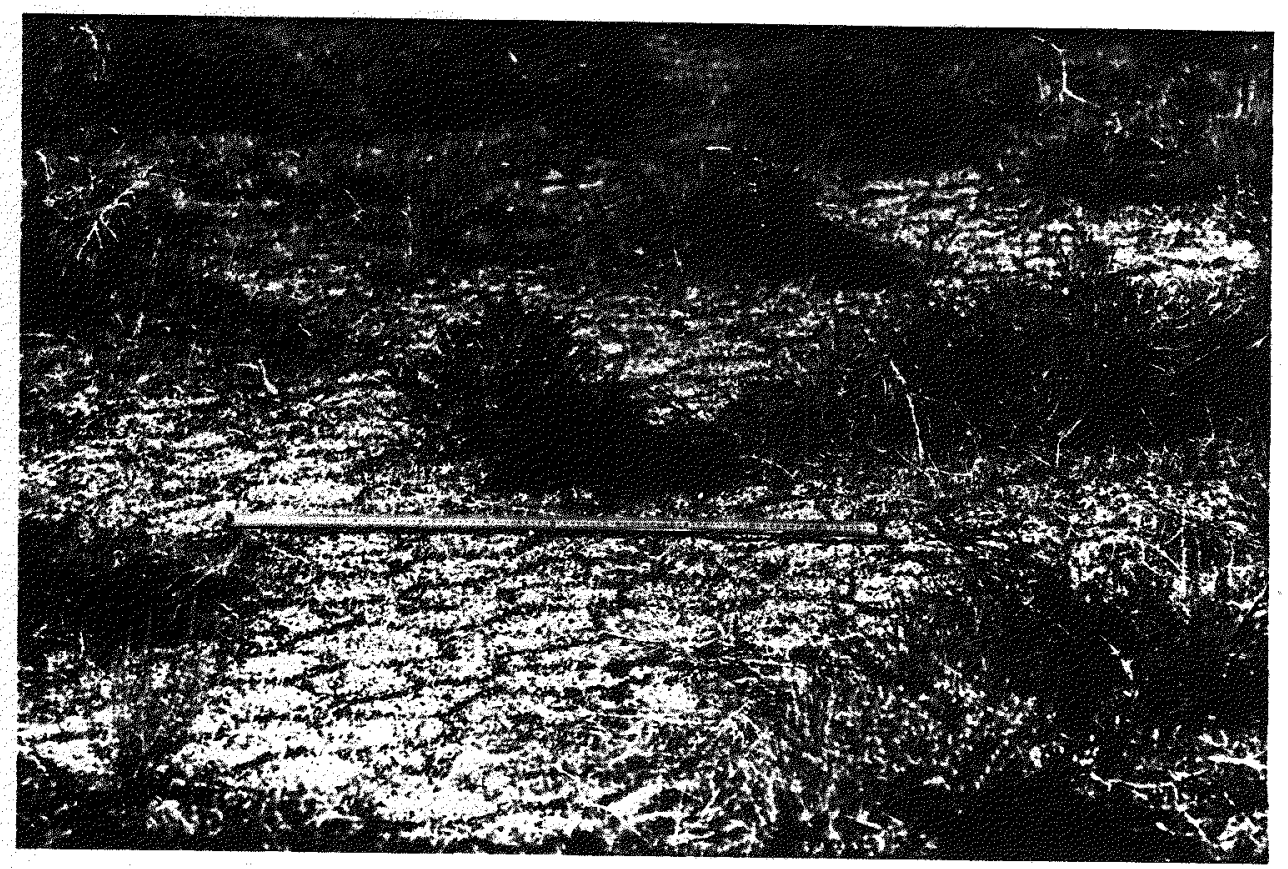

Figure 5a. Area 6 Site: general view of surface and its vegetation cover. Scale bar is $1 \mathrm{~m}$ long.

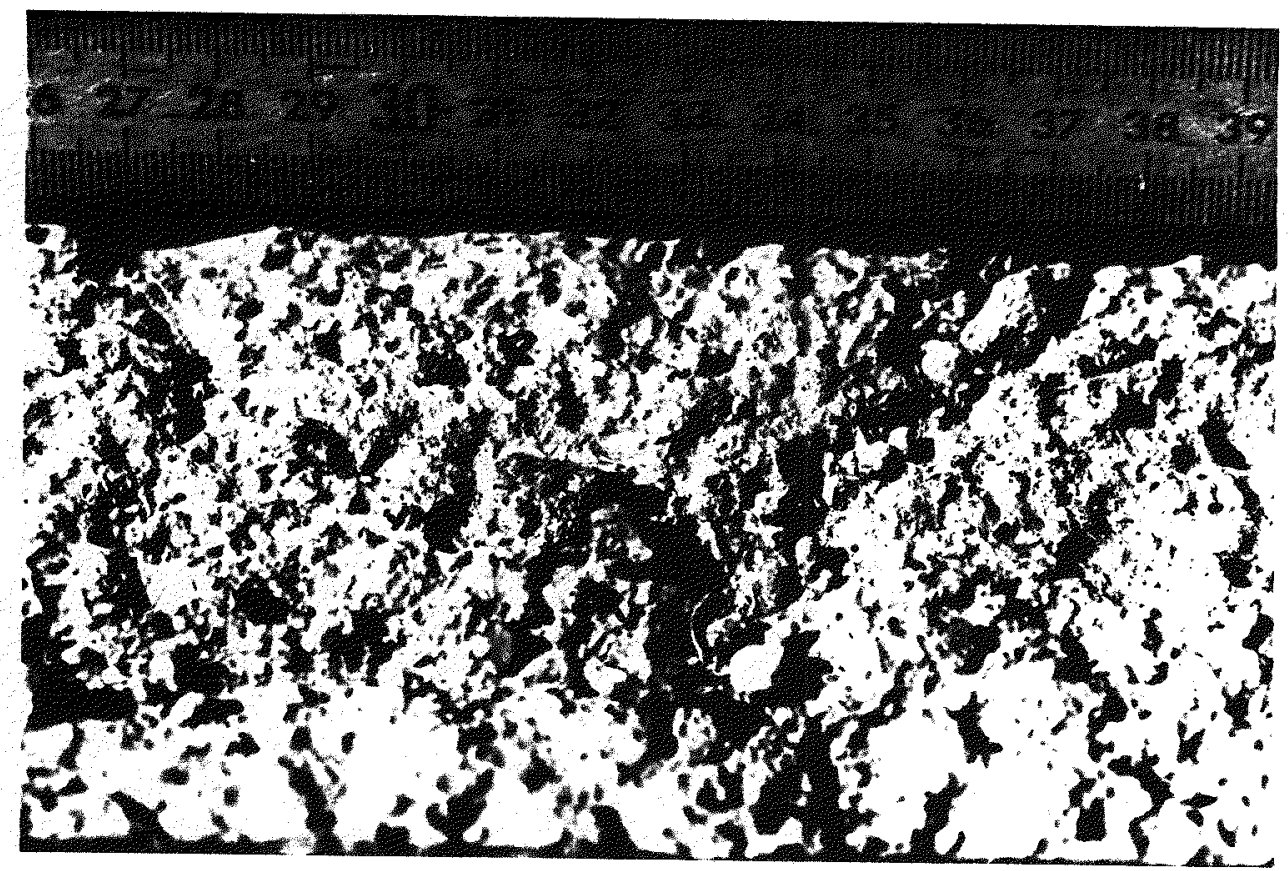

Figure 5b. Area 6 Site: close-up view of surface. Scale is in $\mathrm{cm}$. 


\section{Disturbed surface sites}

These sites were all located in Area 6 adjacent to the Area 6 natural surface wind tunnel tests and 10-m anemometer mast. Truck tires and the Rotomill soil stripper were the disturbing agents. Soil composition was the same as described for Area 6 above.

1. Tire: A pickup truck was driven at $5 \mathrm{mph}$ back and forth once each way across a thin crust that had formed over a two year period on a graded surface. The tires pulverized the crust and left behind a fine dust with the micro-topography of the tire tread pattern. Wind tunnel tests were performed along the tire tracks and are referred to as "Tire Track" (also "TrTrx") and those performed on the unbroken crust are referred to as "Tire Control" (also "TrCntrl").

2. Rotomill: Several test swaths were cut by the Rotomill excavation device in the area referred to as the Habitat Restoration Test Site. The excavation device cut and removed soil to a depth of approximately 15 to $25 \mathrm{~cm}$. The natural surface had been wetted by a water truck prior to the test swaths to suppress dust. Only the last test swath included use of a foam suppression system to control dust. Our wind tunnel tests on each of these surfaces followed the Rotomill by approximately 30 minutes, 24 hours and one week (referred to as Day 1, Day 2 and Week 1, respectively). The wind tunnel tests performed on the water-wetted-only swath are called "RotoDry" (also "RoDry"), while those that followed the water and foam passage are called "RotoFoam" (also "RoFoam"). In both types of test swaths the result was a hard, flat, beveled surface on top of which an intermittent 0.5 - to $1.5-\mathrm{cm}$-thick layer of dust remained (Figure 6a). This dust layer was generally damp following the application of foam (Figure 6b) but the effect was temporary.

\section{RELATIONS BETWEEN BOUNDARY LAYER WINDS AND VEGETATION COVER}

The purpose of the wind profile studies conducted in 1994 was to determine if changes in annual rainfall and vegetation growth have any effect on the protection afforded to the surface by natural vegetation. These studies continue those carried out in 1993. Three sites covering a range of desert surface types and vegetation cover were selected for comparison with the sites used in 1993. At each of these locations, the sites used in 1993 (Gate 2, Joshua, and Bedrock) and described fully in the Fieldwork Report for 1993 were reoccupied. An additional location in Area 6 (Area 6) was located southwest of the Habitat Restoration Test Site, where tests using various excavation devices were conducted in 1994. This site was used to extend our range of surface types to include a crusted silt-clay surface.

\section{Instrumentation}

Two anemometer mast arrays were used in the field experiment. The 10-m mast (Figure 7) was equipped with logarithmically spaced cup-anemometers at heights of $1.00,1.78,3.16,5.62$, and $10.00 \mathrm{~m}$ with a wind direction vane at $10 \mathrm{~m}$. The $6-\mathrm{m}$ mast anemometer heights were $1.00,1.55,2.40$, 3.72 , and $6.00 \mathrm{~m}$ with a wind direction vane at $6 \mathrm{~m}$. The instruments were R.M. Young Wind Sentry 


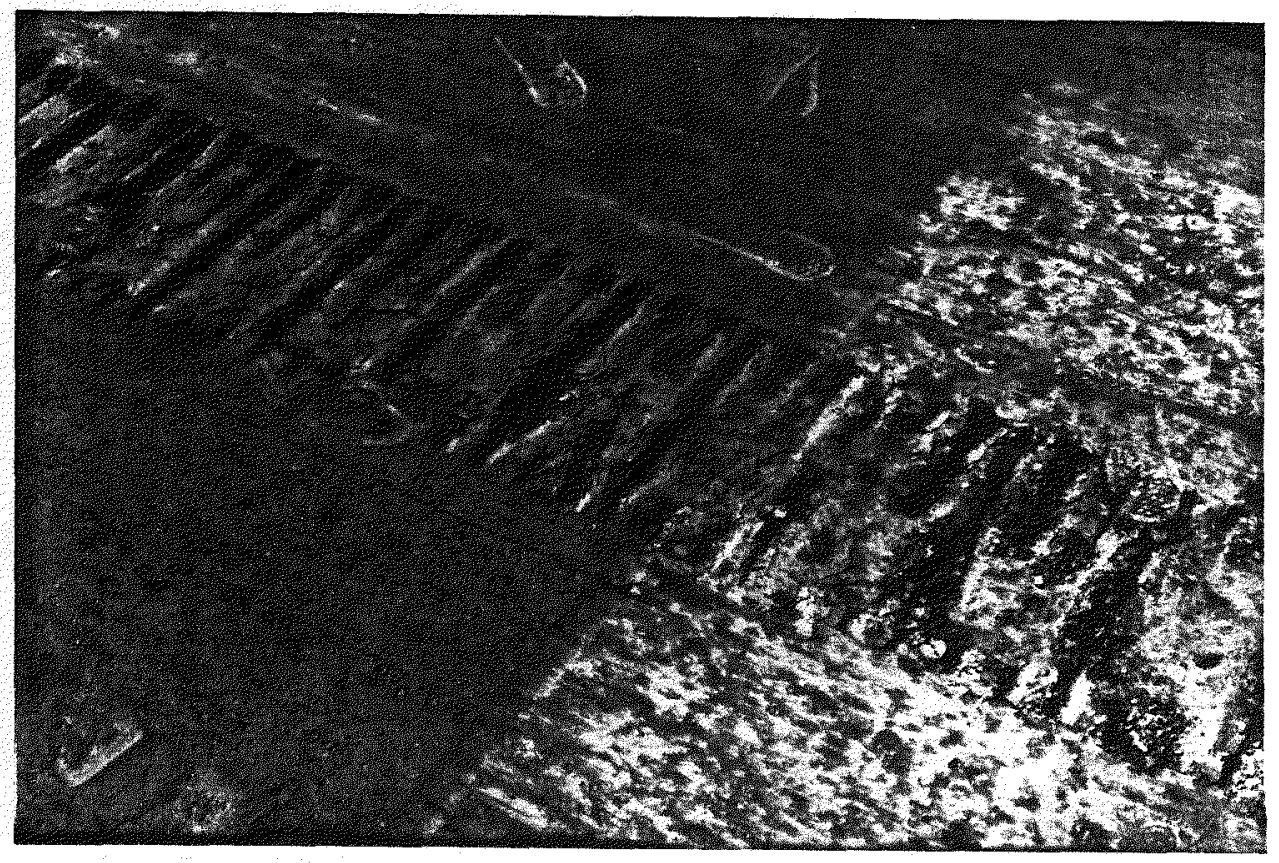

Figure 6a. Rotomill Site: dry surface after passage of excavation device.

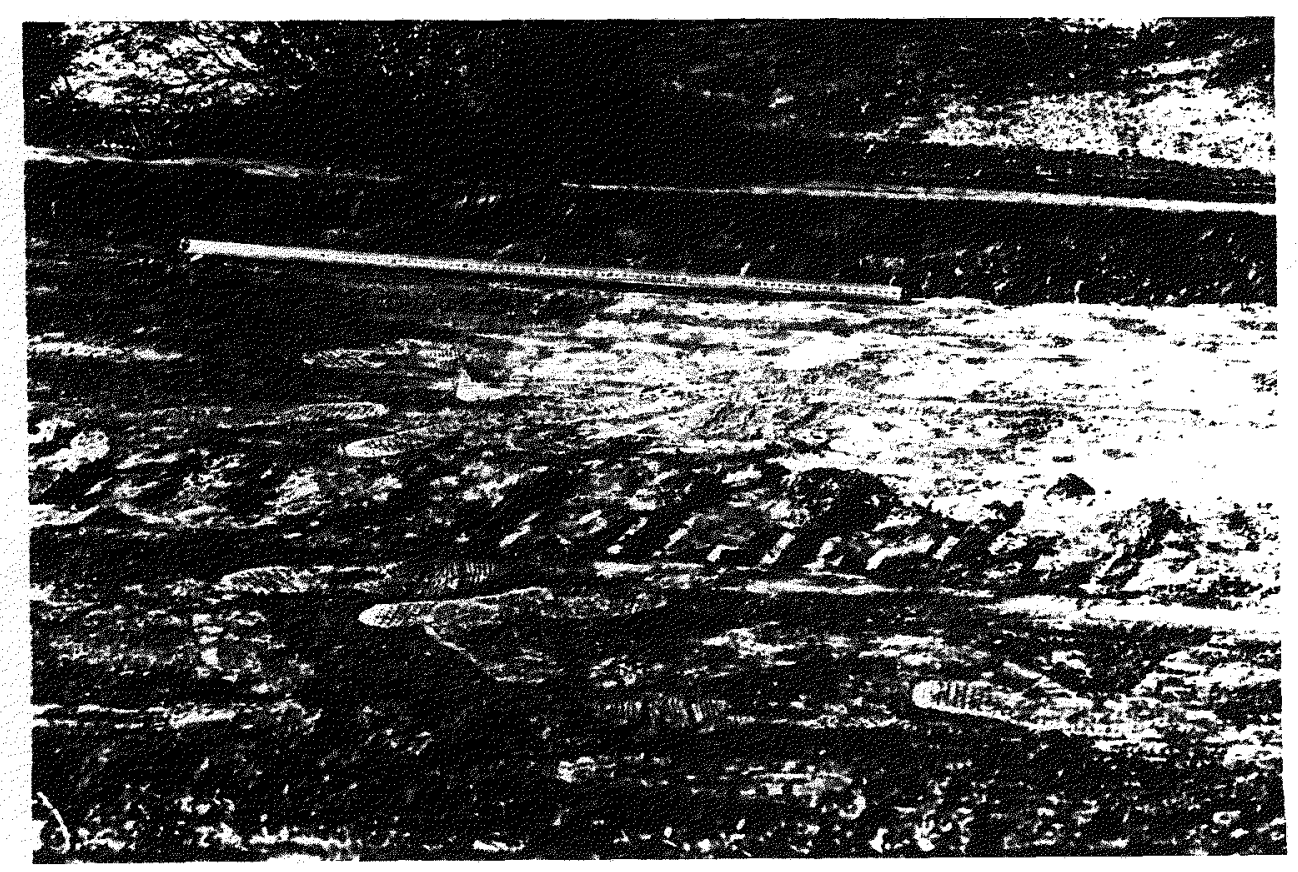

Figure 6b. Rotomill Site: surface of swath cut by excavation device with foam added to water supply. 


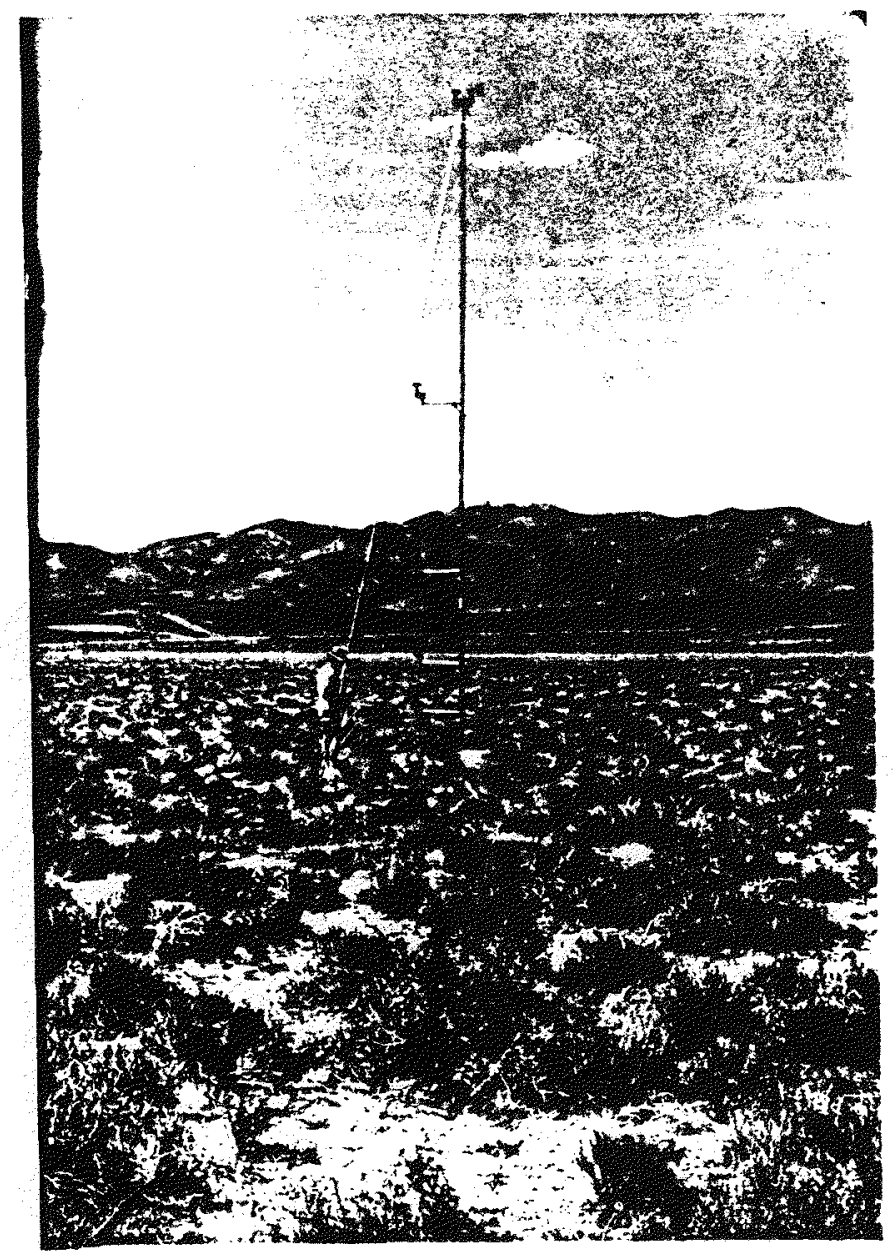

Figure 7. 10-m anemometer mast at Area 6 site.

models with a specified anemometer stall speed of $0.2 \mathrm{~m} / \mathrm{sec}$. Data were recorded with a Campbell Scientific CR-10 datalogger using a sampling interval of two seconds and averaged over a period of 15 minutes. The 10-m mast was deployed at Area 6 for a period of approximately 25 days and the $6-\mathrm{m}$ mast was deployed for periods of four to 19 days at Bedrock, Gate, and Joshua 3.

\section{Wind Data Reduction}

Wind data were reduced using Microsoft Excel ${ }^{\text {TM }}$ spreadsheet software. Data were initially sorted by wind speed at the lowest anemometer $(1 \mathrm{~m})$ and a subset of the data in which the wind speed at the lowest anemometer exceeded $4 \mathrm{~m} / \mathrm{sec}$ was extracted. This was done to avoid problems with 
anemometers stalling at low velocities, to minimize the effects of thermal instability of the atmosphere, and to obtain data for wind speeds potentially capable of transporting sand and dust (Lancaster et al., 1991). Initial data sets ranged between 12 and 115 profiles.

Following Wolfe (1993), the zero-plane displacement (d) was not used in estimating the aerodynamic roughness length, because of its uncertain physical significance. In many instances, use of the zero-plane displacement gives unrealistically low values of aerodynamic roughness and/or negative zero-plane displacement values. The excellent fit to the wind profile data using the basic Prandtl-von Karman equation appears to justify our approach.

These data were used for subsequent calculations of aerodynamic roughness $\left(\mathrm{z}_{\mathrm{o}}\right)$ and wind shear velocity $\left(u_{*}\right)$ using a least squares fit to the data. Thus, given a linear fit of the form $y=m x$ $+b$, where $y$ is $u, x$ is $\ln (z), b$ is $-\left(u_{*} / \kappa\right) \ln z_{0}$ and $m$ is $u * / \kappa$,

$$
\mathrm{u} *=\mathrm{Km}
$$

and

$$
\mathrm{z}_{\mathrm{o}}=\mathrm{e}^{-\mathrm{b} / \mathrm{m}}
$$

where $\kappa$ is the Von Karmann constant (0.4).

Several checks were placed on the calculations of wind profile parameters following the methods outlined by Bauer et al. (1992). For each profile, the least squares error (normalized to $\mathrm{r}^{2}$, the coefficient of determination) for the estimates of $\mathrm{z}_{\mathrm{O}}$ and $\mathrm{u} *$ was calculated using the following equations:

$$
\begin{gathered}
\text { Error }\left(\mathrm{u}_{*}\right)=1 / \mathrm{r}^{2}-1 \\
\text { Error }\left(\mathrm{z}_{\mathrm{O}}\right)=\mathrm{e}^{(\mathrm{u} / \mathrm{m})\left(1-\mathrm{r}^{2}\right)}-1
\end{gathered}
$$

where $\mathrm{u}$ is the mean wind speed. The maximum acceptable error in estimating $\mathrm{z}_{\mathrm{o}}$ was set at $5 \%$. Profiles for which the error exceeded this limit were rejected.

\section{Results}

Estimates of aerodynamic roughness $\left(\mathrm{z}_{0}\right)$ and wind shear velocity are given in Table 1 , and examples of the wind profiles in Figure 8. Appendix 1 contains the full set of data that met the criteria discussed above. Values of aerodynamic roughness range from $0.0290 \mathrm{~m}$ at Gate 2 to $0.0619 \mathrm{~m}$ at Joshua. They tend to increase in a general way with the density and height of the vegetation cover. The values of aerodynamic roughness are within the range of those obtained for grass and low crops summarized in Garratt (1992) and compare well with those obtained for other forms of desert vegetation discussed in Wolfe and Nickling (1993). They also compare well with the value of $0.03 \pm 0.5 \mathrm{~m}$ obtained by Shinn et al. (1989) for Area 11 . 
TABLE 1. WIND PROFILE PARAMETERS AT INVESTIGATED SITES, 1994.

\begin{tabular}{ccccc}
\hline \multicolumn{1}{c}{ Site } & Bedrock & Gate 2 & Joshua & Area 6 \\
\hline Aerodynamic Roughness (m) & & & \\
Arith Mean & 0.0415 & 0.0290 & 0.0619 & 0.0244 \\
Std Deviation & 0.0120 & 0.0051 & 0.0106 & 0.0248 \\
Wind shear velocity $(\mathrm{m} / \mathrm{sec})$ & & & \\
Arith Mean & 0.58 & 0.54 & 0.68 & 0.31 \\
Std Dev & 0.08 & 0.06 & 0.08 & 0.10 \\
\hline \hline
\end{tabular}
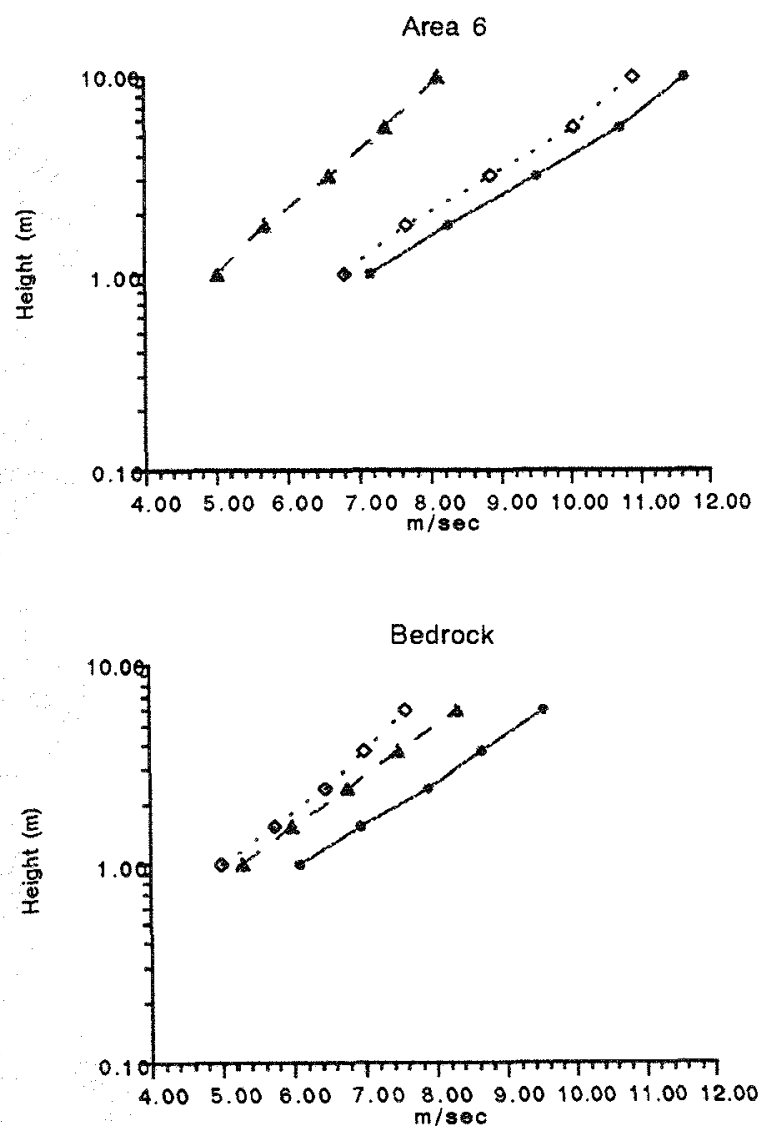
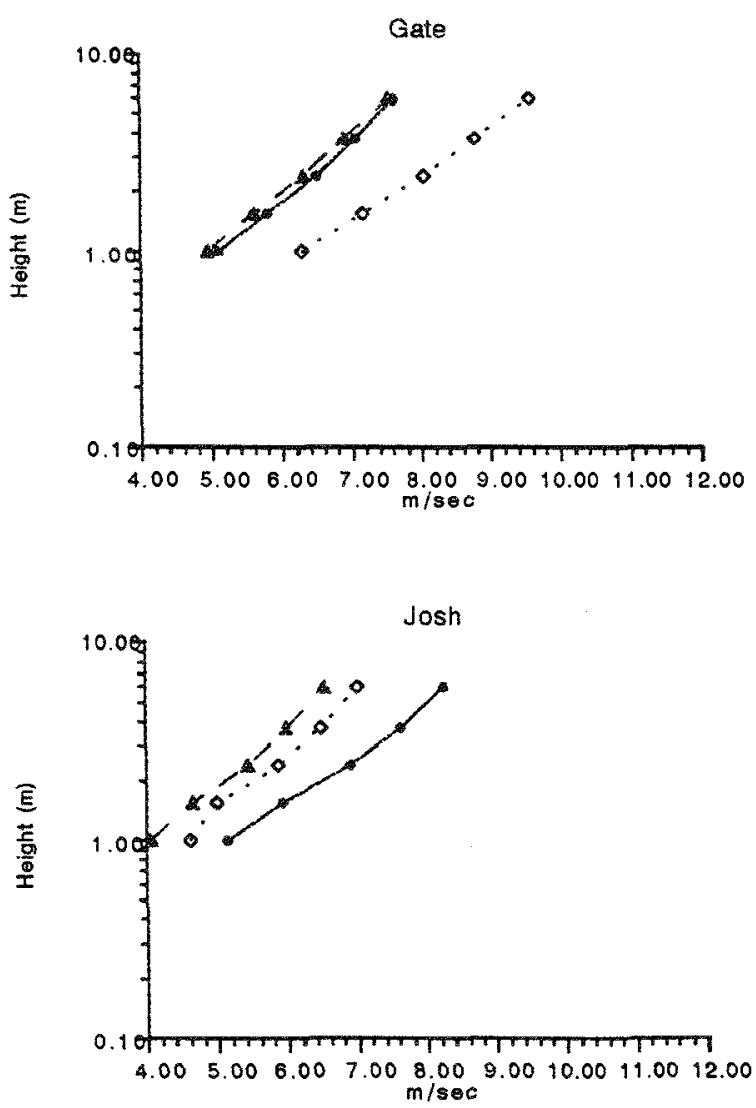

Figure 8. Representative wind profiles for investigated sites. 


\section{VEGETATION MEASUREMENTS}

\section{Methods}

Vegetation was measured at each anemometer site to estimate its capacity to protect erodible soils available for resuspension. Vegetation at the soil surface absorbs part of the wind shear stress (shear stress partitioning) and thus protects soil surfaces from wind erosion. The protection afforded to the soil surface by vegetation is described by its lateral cover $\left(\mathrm{L}_{\mathrm{c}}\right)$, which is a function of vegetation distribution and profile. $L_{c}$ values were calculated at each site for shrubs and grasses by species. The measured vegetation was in close proximity to the anemometer masts and oriented toward the predominant wind direction.

To determine shrub density ( $\mathrm{D}_{\text {shrubs }}$ ), a $25-\mathrm{m}$ by $25-\mathrm{m}$ plot was laid out and the quantity of each species present was recorded. To obtain the mean-silhouette area $\left(\mathrm{S}_{\text {shrubs }}\right)$, four line transects $25 \mathrm{~m}$ long were utilized. Each shrub located on the line transect was measured for its height and diameter. Height was measured from the ground surface at the edge of the plant to the maximum height of an imaginary cylinder encompassing the bulk of the shrub but excluding random branches that may extend beyond this imaginary cylinder. Shrub diameter was taken as the average of the longest and shortest diameters measured across the imaginary cylinder. The values for each shrub's height and diameter were multiplied together to determine its silhouette area. The silhouette area values for each species were then averaged to determine a representative value for each species. The final values of $D_{\text {shrubs }}$ and $S_{\text {shrubs }}$ for each species are multiplied together for the final species value of $\mathrm{L}_{\mathfrak{c}}$ and are represented in the table for perennial and annual species.

To assess the $\mathrm{L}_{c}$ afforded by grasses, similar methods were used with the assistance of a $1-m$-square plot-frame. To determine the density of the grass $\left(\mathrm{D}_{\text {grass }}\right)$, the plot-frame was placed at three random locations on the line transects and each grass species present was counted and then averaged among the three plots. This determined the quantity of each grass species present to the total grass coverage for a given unit of area $\left(1 \mathrm{~m}^{2}\right)$. The amount of total grass coverage at each site was visually estimated and then multiplied by the number of each species per unit area.

To calculate $\left(S_{\text {grass }}\right), 10$ specimens of each grass species were measured for their diameter and height and then these values were multiplied to derive their silhouette area. Then the silhouette area values were averaged for each species to determine a representative value for the species. The final values of $D_{\text {grass }}$ and $S_{\text {grass }}$ for each species were multiplied together for the final species value of $\mathrm{L}_{\mathrm{c}}$ and were tabulated (Appendix 2) by perennial and annual species.

\section{Results}

Lateral cover measurements are given in full in Appendix 2 and are summarized in Table 2. The lateral cover $\left(\mathrm{L}_{\mathrm{c}}\right)$ values for vegetation at very similar or identical sites between the years 1993 and 1994 are given in Tables 3 through 5 . Total $L_{c}$ values were generally lower for 1994 compared to 1993 as a result of low rainfall in the winter of 1993 - 1994. This was evident by the lack of new growth, an increased number of dead perennial shrubs, less annual shrubs, and a drastic decrease of grasses, especially annual species. Rainfall totals at Desert Rock station were only 2.19 inches 
for the year July - June 1993-94, compared to 8.99 inches for the preceding year and 6.97 inches for 1991-1992.

TABLE 2. COMPARISON OF AERODYNAMIC ROUGHNESS ESTIMATES (M) BETWEEN 1993 AND 1994.

\begin{tabular}{ccc}
\hline & 1993 & 1994 \\
\hline Bedrock & 0.0281 & 0.0415 \\
Gate 2 & 0.0395 & 0.0290 \\
Josh & 0.0447 & 0.0619 \\
\hline \hline
\end{tabular}

Table 3 shows the large difference between the total $L_{c}$ values for the 1993 and 1994 Gate sites. The Gate 1993 site had a $L_{c}$ value of 0.4174 , while the Gate 1994 site has a value of 0.1441 . At this site, the largest difference between the two years is among annual shrubs. A closer investigation of the annual shrub data shows that the same shrub species existed between the two years, but in substantially lower quantities in 1994. Perennial shrubs show a decrease of 15 times due to an increase in dead species which decay to a smaller size resulting in a lower $\mathrm{L}_{c}$ values. Perennial grasses and forbs and groundcover differed by three times due to a reduction in quantity, while $\mathrm{L}_{\mathrm{c}}$ values per specimen remained similar. Annual grasses and forbs and groundcover differed by two times due to a reduction in quantity.

TABLE 3. COMPARISON BETWEEN 1993 AND 1994 LATERAL COVER AT GATE SITES.

\begin{tabular}{lcc}
\hline \hline Location & Gate2 ('93) & Gate ('94) \\
\hline Total $\mathrm{L}_{\mathrm{c}}$ & .4174 & .1441 \\
Perennial Grasses / Forbs \& Groundcover $\mathrm{L}_{\mathrm{c}}$ & .0300 & .0112 \\
Perennial Shrubs $\mathrm{L}_{\mathrm{c}}$ & .0998 & .0066 \\
Annual Grasses / Forbs \& Groundcover $\mathrm{L}_{\mathrm{c}}$ & .2565 & .1256 \\
Annual Shrubs $\mathrm{L}_{\mathrm{c}}$ & .0311 & .0007 \\
\hline \hline
\end{tabular}

The most similar values between 1993 and 1994 occurred at the Bedrock sites (Table 4). The Bedrock 1993 site has a $L_{c}$ value of 0.2059 , while the Bedrock 1994 site has a value of 0.2170 . The only significant deviation in $\mathrm{L}_{\mathrm{c}}$ values was between perennial grasses and forbs and groundcover. The only species in the category was Indian ricegrass (Oryzopsis hymenoides) and the difference was due to the smaller size rather than quantity.

The significance of changes at the Josh site (Table 5) is difficult to evaluate. The first point to note is that there is a fairly large discrepancy between Josh 1 (1993) and Josh 2 (1993) values. The only similarity in values is among annual grasses and forbs and groundcover. The lack of consistency between these two 1993 sites makes comparison with 1994 problematic and statistically weak. However, Josh (1994) shows no perennial grasses and forbs and groundcover and annual shrubs, 
much lower values for annual grasses and forbs and groundcover, but does have a perennial shrub value within the range of the 1993 values.

TABLE 4. COMPARISON BETWEEN 1993 AND 1994 LATERAL COVER AT BEDROCK SITES.

\begin{tabular}{lcc}
\hline \hline Location & Bedrock ('93) & Bedrock ('94) \\
\hline Total $\mathrm{L}_{\mathrm{c}}$ & .2059 & .2170 \\
Perennial Grasses / Forbs \& Groundcover $\mathrm{L}_{\mathrm{c}}$ & .0060 & .0019 \\
Perennial Shrubs $\mathrm{L}_{\mathrm{c}}$ & .0932 & .1425 \\
Annual Grasses / Forbs \& Groundcover $\mathrm{L}_{\mathrm{c}}$ & .0984 & .0635 \\
Annual Shrubs $\mathrm{L}_{\mathrm{c}}$ & .0083 & .0091 \\
\hline \hline
\end{tabular}

TABLE 5. COMPARISON BETWEEN 1993 AND 1994 LATERAL COVER AT JOSH SITES.

\begin{tabular}{lccc}
\hline \hline Location & Josh 1 ('93) & Josh 2('93) & Josh ('94) \\
\hline Total $\mathrm{L}_{\mathrm{c}}$ & .3905 & .3076 & .1387 \\
Perennial Grasses / Forbs \& Groundcover $\mathrm{L}_{\mathrm{c}}$ & .0015 & .0136 & 0 \\
Perennial Shrubs $\mathrm{L}_{\mathrm{c}}$ & .1678 & .0369 & .0694 \\
Annual Grasses / Forbs \& Groundcover $\mathrm{L}_{\mathrm{c}}$ & .1895 & .1963 & .0693 \\
Annual Shrubs $\mathrm{L}_{\mathrm{c}}$ & .0317 & .0608 & 0 \\
\hline \hline
\end{tabular}

\section{Relations between vegetation cover and wind profile characteristics}

Aerodynamic roughness is a measure of the effect of roughness elements on the surface wind. Many investigators have shown that aerodynamic roughness increases with greater height and density of both vegetation cover and artificial roughness elements.

Considered separately, the aerodynamic roughness - total lateral cover relations for both the 1993 and 1994 indicate a general increase in aerodynamic roughness with increasing total lateral cover. Taking both data sets together, the strongest relation to emerge is a trend of increasing aerodynamic roughness with the proportion of the lateral cover composed of shrubs (Figure 9). This reinforces the conclusion reached in 1993 that the aerodynamic roughness of the investigated sites is determined largely by the lateral cover of the larger and more permanent roughness elements.

It is clear from Tables 3 through 5 that some significant changes in total lateral cover occurred from 1993 to 1994. Except at the Gate site, however, the percentage of the lateral cover attributable to shrubs in 1994 was within 6 to $7 \%$ of that in 1993. At Gate, only $5 \%$ of the lateral cover was attributable to shrubs in 1994 , compared to $31 \%$ in the previous year. Estimates of aerodynamic roughness varied from 1993 to 1994 in the following way: at Gate, aerodynamic roughness in 1994 was 0.73 of that in 1994, whereas at Bedrock and Josh, aerodynamic roughness in 1994 was 1.48 and 1.38 of the 1993 values. 


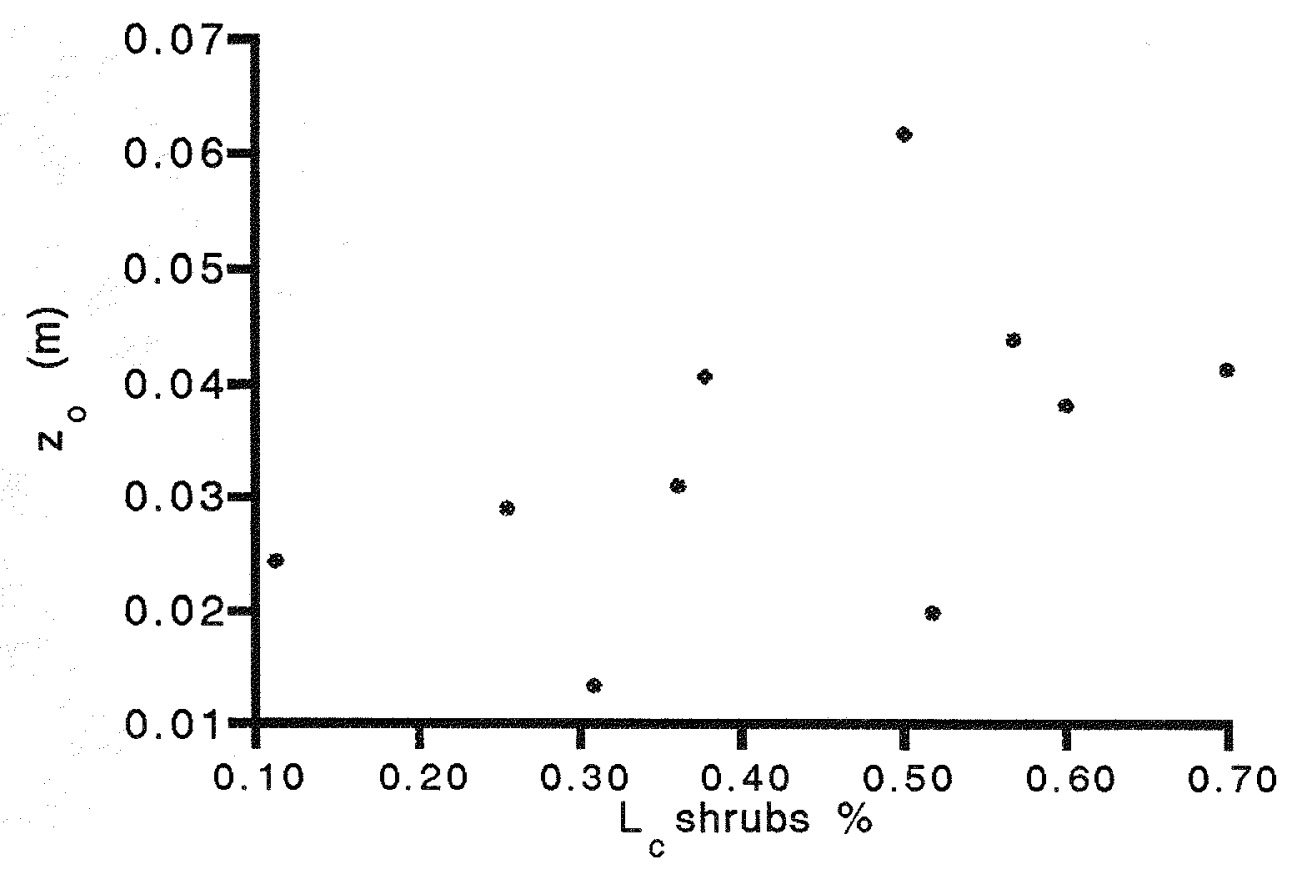

Figure 9. Relations between aerodynamic roughness and shrub lateral cover (normalized to total lateral cover for each site). Data from 1993 and 1994 experiments included.

It is difficult to derive any unambiguous conclusions from these data, except that the largest decrease in aerodynamic roughness occurred at the site (Gate) where both the lateral shrub cover as a percent of the total lateral cover and the total lateral cover decreased the most. It is probable that the vegetation changes at Bedrock were too small to significantly affect the aerodynamic roughness of this surface.

\section{WIND TUNNEL STUDIES}

The purpose of the wind tunnel studies was to determine threshold wind shear velocities for the input of surface particles into the air. Studies were conducted on natural surfaces as well as various disturbed surfaces of different characteristics (described above). Use of a wind tunnel permits determination of threshold parameters under controlled conditions.

\section{Description of Wind Tunnel and its Operation}

The wind tunnel is designed to simulate a turbulent boundary layer over natural and disturbed soil surfaces. It is based on a design documented by Gillette (1978). Below is a brief description of the wind tunnel and the operating procedures used this year. A formal standard operating procedure (SOP) for Q/A requirements is currently being developed. 
The wind tunnel (Figure 10) is a pull-through design. Air enters the inlet section $(61 \times 15 \mathrm{~cm})$ via a honeycomb flow straightener and is compressed laterally at a $4: 1$ ratio. The working section has a total length of $457 \mathrm{~cm}$ and a cross-sectional area of $232 \mathrm{sq} . \mathrm{cm}(15 \times 15 \mathrm{~cm})$. The ground surface forms the floor of the tunnel. Air speed through the tunnel is measured at the lateral midpoint, 380 $\mathrm{cm}$ into the working section, using a pitot tube and magnehelic pressure gauge. Data for the profiles are measured at $5,10,20,30, \ldots, 120 \mathrm{~mm}$ above the surface. The flow velocity is regulated by means of a bypass throttle opening in the tail section.

The threshold for particle movement was determined visually. If silt, sand or aggregate movement was observed, the by-pass opening would be recorded and three velocity profiles would be made from surface to ceiling. Subsequently, a second set of three profiles was recorded at an air speed slightly below the entrainment speed first observed. If no entrainment motion could be detected for a given surface, one set of three profiles was made with the by-pass at $15 \mathrm{~cm}$ and another set with the by-pass at $8 \mathrm{~cm}$. Three tunnel sites were tested at each of the four study areas.

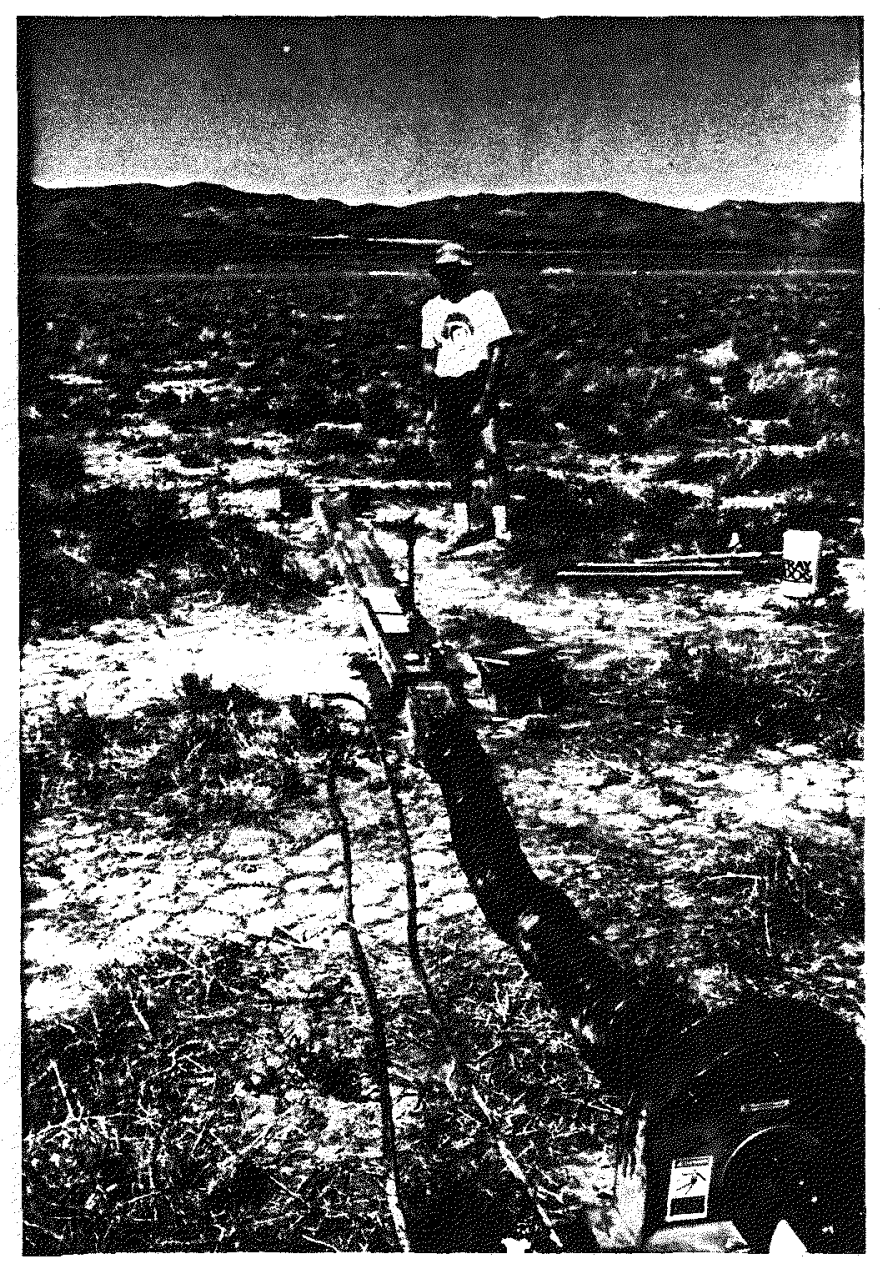

Figure 10. The wind tunnel as deployed at the Area 6 site. 


\section{Data Reduction}

Field measurements of airflow were recorded as inches of mercury and converted to wind speed in meters per second using the manufacturer's calibration for the pitot tube. Each wind profile was then graphed and inspected for outlying data points. These data were used for subsequent calculations of aerodynamic roughness $\left(\mathrm{z}_{\mathrm{o}}\right)$ and wind shear velocity $(\mathrm{u} *)$ using a least squares fit to the data. Several checks were placed on the calculations of wind profile parameters following the methods outlined above. The maximum acceptable error in estimating $z_{0}$ was set at $10 \%$. Profiles for which the error exceeded this limit were rejected.

\section{Measurement of Surface Characteristics}

Twenty penetrometer tests were performed adjacent to each wind tunnel test site on both the natural and disturbed surfaces to characterize their ground strength. The penetrometer instrument was applied only to exposed silt/sand matrix between any pebble clasts so that the probe "footprint" was not affected by variable clast dimensions. Although the gauge measured a range from $0.2 \mathrm{~kg} / \mathrm{sq}$ $\mathrm{cm}$ to $4.5 \mathrm{~kg} / \mathrm{sq} \mathrm{cm}$, many of the surfaces were either too weak or too strong for that scale. Such data were recorded as $<0.2$ and $>4.5$, respectively, making it impossible to calculate the ground strength mean and standard deviation. Therefore, the data are presented visually (Figure 11) to characterize ground strength qualitatively. The plots show each location's cumulative samples of all three of the tunnel sites.

Based on the penetrometer graphs (Figure 11), all of the natural surfaces can be described as being quite weak. Area 6 had the widest range of strengths, yet most are at the low end of the scale. Both the tire tracks and the unbroken crust of the tire control section are weak as well. Only the surfaces over which the Rotomill had passed have a significant ground strength, with the foamed surface appearing to be the strongest.

\section{Wind Tunnel Results}

Representative wind tunnel profiles for each site and location are given in Figure 12. The full data set is included as Appendices 3 and 4 . The threshold wind shear velocity $(\mathrm{u} *)$, aerodynamic roughness length $\left(\mathrm{z}_{\mathrm{o}}\right)$, and wind speed at a height of $10 \mathrm{~m}$ that is equivalent to the measured threshold wind shear velocity are given in Table 6 for natural and undisturbed sites and Table 7 for disturbed sites. The 10-m-height wind speed equivalent to that measured in the wind tunnel was calculated using the wind profile equation (equation (1)).

For natural sites, the threshold wind shear velocity was in excess of $1.0 \mathrm{~m} / \mathrm{sec}$ at all locations. Entrainment threshold was not reached at two locations (Area 6 and Bedrock) even though wind shear velocities of greater than 0.967 and $1.083 \mathrm{~m} / \mathrm{sec}$ were attained in the wind tunnel. These entrainment thresholds are equivalent to a wind speed of more than $20 \mathrm{~m} / \mathrm{sec}$ at a height $10 \mathrm{~m}$.

For the disturbed sites, entrainment was attained with the Rotomill test that involved no treatment (apart from pre-wetting of the area) at a threshold wind shear velocity of $0.87 \mathrm{~m} / \mathrm{sec}$. Threshold was, however, not reached on the day following the test. One week later, entrainment was 

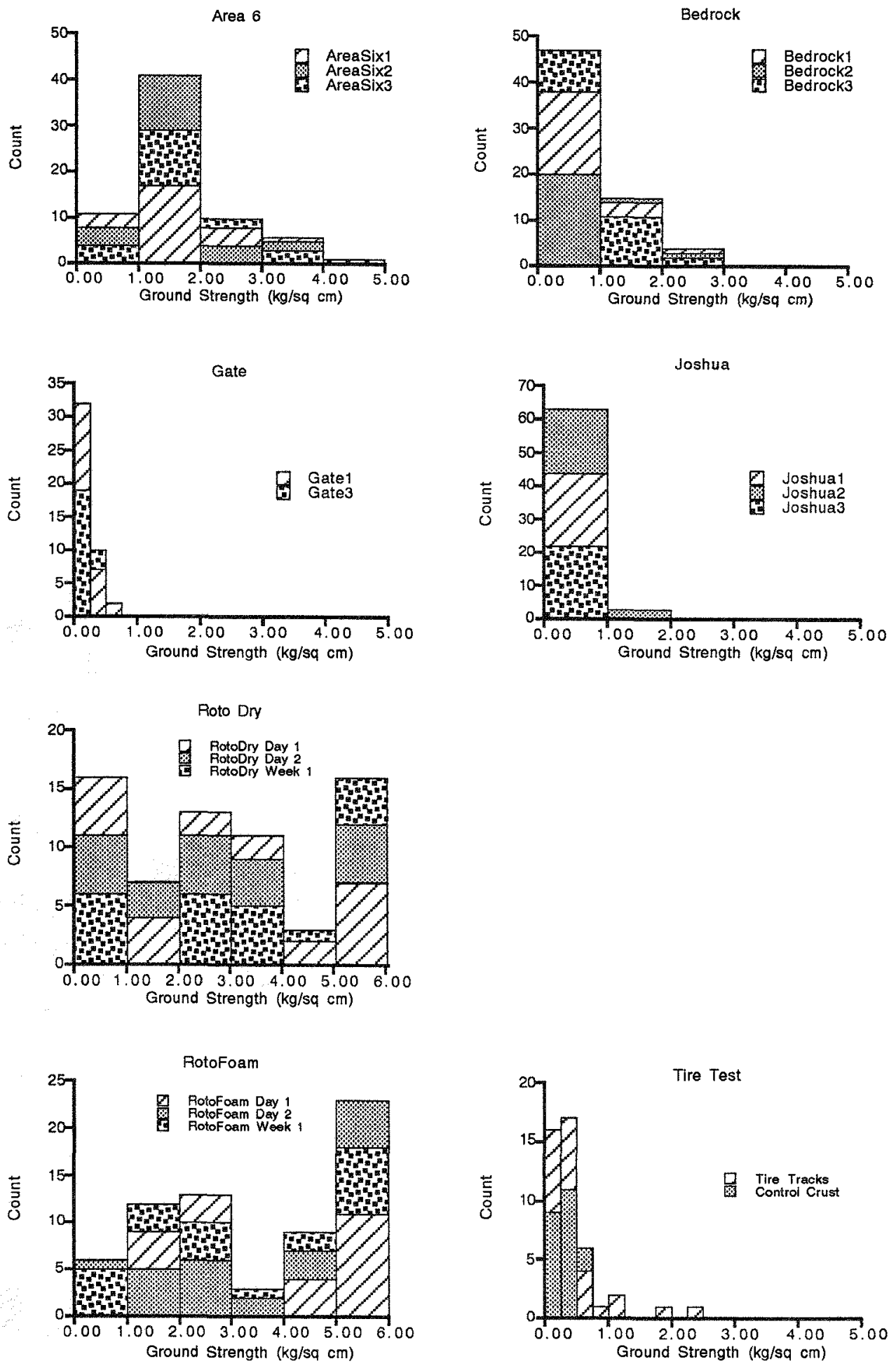

Figure 11. Histograms of penetrometer values at natural and disturbed sites. 


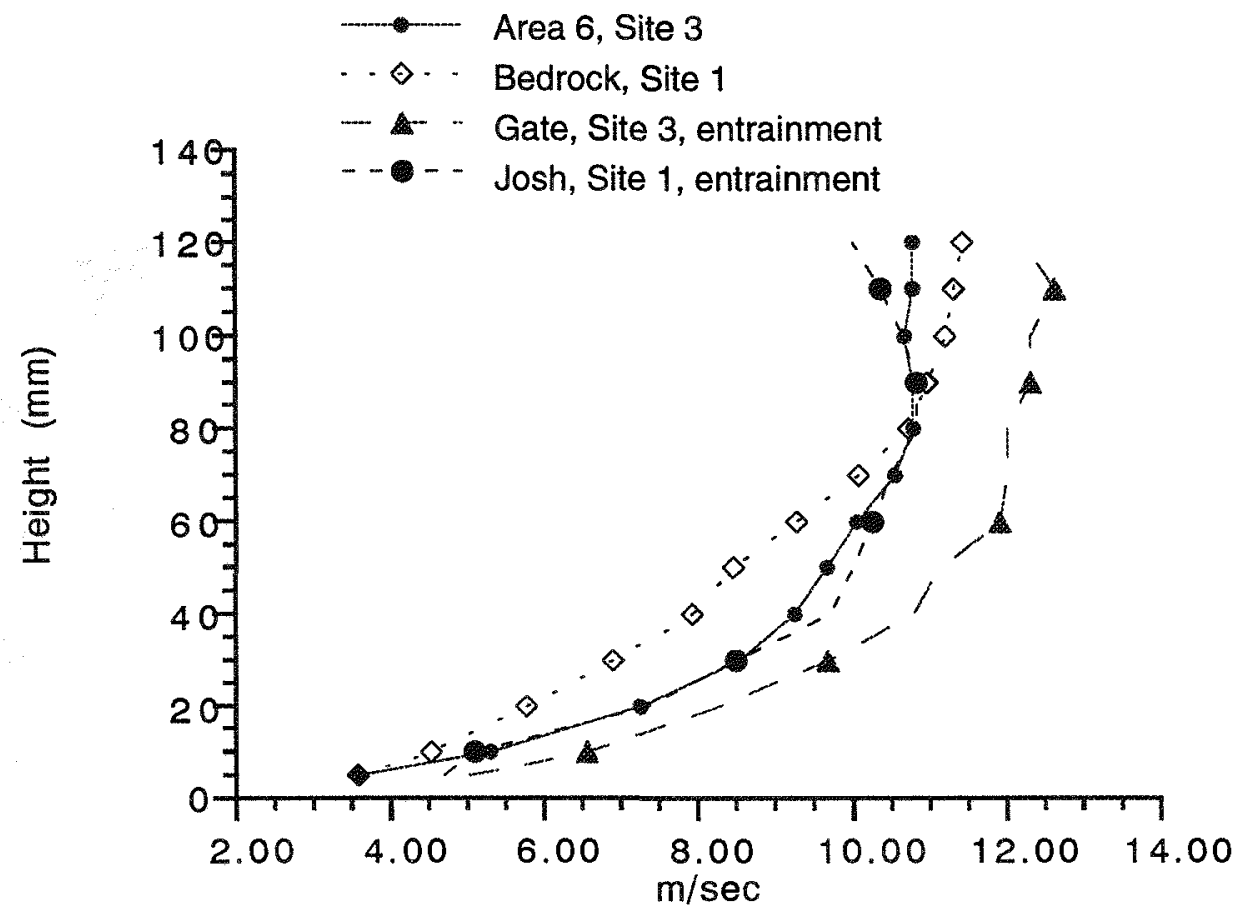

Figure 12. Representative wind tunnel profiles for natural sites.

achieved at a threshold wind shear velocity of $0.561 \mathrm{~m} / \mathrm{sec}$, or $54 \%$ of the initial value. This pattern is attributed to crusting of the surface immediately following the Rotomill test as residual surface moisture was evaporated.

TABLE 6. ENTRAINMENT THRESHOLDS FOR NATURAL SURFACES. Standard deviations for roughness length and threshold wind shear velocity are given in parentheses.

\begin{tabular}{llccc}
\hline $\begin{array}{c}\text { Location } \\
\text { (number } \\
\text { of tests) }\end{array}$ & \multicolumn{1}{c}{ Surface Type } & $\begin{array}{c}\text { Aerodynamic } \\
\text { Roughness Length } \\
(\mathrm{m})\end{array}$ & $\begin{array}{c}\text { Threshold wind } \\
\text { shear velocity }(\mathrm{u} *) \\
(\mathrm{m} / \mathrm{sec})\end{array}$ & $\begin{array}{c}\text { Equivalent wind } \\
\text { speed at } 10 \mathrm{~m} \\
\text { height } \\
(\mathrm{m} / \mathrm{sec})\end{array}$ \\
\hline Area 6(6) & $\begin{array}{l}\text { Silt - clay crusted } \\
\text { playa margin }\end{array}$ & $0.00137(0.0003)$ & $>0.967 \mathrm{NR}(0.0735)$ & 21.51 \\
Gate 2 (7) & Desert pavement & $0.00228(0.00135$ & $1.237(0.168)$ & 25.93 \\
Bedrock (7) & Desert pavement & $0.00108(0.0002)$ & $>1.083 \mathrm{NR}(0.1696)$ & 24.74 \\
Joshua (6) & Silty desert pavement & $0.00227(0.0022)$ & $1.300(0.479)$ & 27.27 \\
\hline \hline
\end{tabular}

NR - entrainment threshold not reached in tests 
TABLE 7. ENTRAINMENT THRESHOLDS FOR DISTURBED SURFACES. Standard deviations for roughness length and threshold wind shear velocity are given in parentheses.

\begin{tabular}{|c|c|c|c|c|}
\hline $\begin{array}{l}\text { Location } \\
\text { (number } \\
\text { of tests) }\end{array}$ & Surface Type & $\begin{array}{l}\text { Aerodynamic } \\
\text { Roughness Length } \\
(\mathrm{m})\end{array}$ & $\begin{array}{l}\text { Threshold Wind } \\
\text { Shear Velocity }(\mathrm{u} *) \\
(\mathrm{m} / \mathrm{sec})\end{array}$ & $\begin{array}{c}\text { Equivalent Wind } \\
\text { Speed at } 10 \mathrm{~m} \\
\text { Height } \\
(\mathrm{m} / \mathrm{sec})\end{array}$ \\
\hline \multicolumn{5}{|l|}{ Rotomill (dry) } \\
\hline Day 1 (1) & $\begin{array}{l}\text { Silt clay (freshly } \\
\text { trimmed) }\end{array}$ & 0.0821 & 0.87 & 10.45 \\
\hline Day $2(1)^{*}$ & $\begin{array}{l}\text { Silt clay (trimmed day } \\
\text { before) }\end{array}$ & 0.00021 & $>0.386 \mathrm{NR}$ & $>10.40$ \\
\hline Day 7(3) & Silt clay & $0.00021(0.00004)$ & $0.561(0.0083)$ & 15.11 \\
\hline \multicolumn{5}{|c|}{ Rotomill (foam) } \\
\hline Day $1(2)^{*}$ & $\begin{array}{l}\text { Damp silt clay } \\
\text { (freshly trimmed) }\end{array}$ & 0.00004 & $>0.307 \mathrm{NR}$ & $>9.56$ \\
\hline Day 2 (2) & $\begin{array}{l}\text { Silt clay (trimmed day } \\
\text { before) }\end{array}$ & 0.00172 & $>0.61 \mathrm{NR}$ & $>13.22$ \\
\hline Day 7 (2) & Silt clay & 0.00021 & 0.490 & 13.19 \\
\hline \multicolumn{5}{|l|}{ Tire Tracks } \\
\hline Control (3) & $\begin{array}{l}\text { Crusted bladed } \\
\text { silt-clay }\end{array}$ & $0.00015(0.0001)$ & $>0.762 \mathrm{NR}(0.051)$ & $>21.16$ \\
\hline Disturbed (2) & Vehicle track & 0.00207 & 0.6218 & 13.19 \\
\hline
\end{tabular}

NR - entrainment threshold not reached in tests

* - data included for comparison, although they do not meet criteria for inclusion of profile in data set.

By contrast, entrainment thresholds were not attained immediately following and one day after the passage of the Rotomill in tests that involved the addition of surfactant foam to the Rotomill water supply. However, one week later, entrainment was achieved with a threshold wind shear velocity of $0.528 \mathrm{~m} / \mathrm{sec}$-- very similar to that obtained from the untreated Rotomill site.

A test of the effects of disturbance of surfaces by motor vehicles indicated that the threshold wind shear velocity for the control surface was in excess of $0.762 \mathrm{~m} / \mathrm{sec}$, whereas the disturbed surface had a threshold wind shear velocity of $0.622 \mathrm{~m} / \mathrm{sec}$, or a maximum $81 \%$ of the control surface.

\section{Discussion}

These initial results from wind tunnel testing indicate that for natural, undisturbed sites there was good reproducibility of repeated tests at the same site and a good degree of similarity at different sites at the same locality. For disturbed localities, the variability between different sites of the same surface type and apparent degree of disturbance was much higher.

The tests show that the natural surfaces examined on the Nevada Test Site are very stable to wind erosion. Disturbance of these surfaces reduces the threshold wind shear velocities required for 
entrainment by as much as 50\% (Figure 13). Differences in the pre-treatment of surfaces prior to excavation only affect the subsequent wind erosion susceptibility for a short time. Entrainment thresholds for both Rotomill surfaces examined were essentially identical one week following excavation.

These tests can be compared with data obtained from natural and disturbed desert surfaces using a similar wind tunnel by Gillette et al. (1980). This group found that threshold wind shear velocities for natural undisturbed surfaces comparable to those investigated here were generally in excess of $1.00 \mathrm{~m} / \mathrm{sec}$. Entrainment thresholds for desert pavement surfaces ranged between 1.63 and $2.78 \mathrm{~m} / \mathrm{sec}$, whereas those for a variety of crusted soils were greater than $1.21 \mathrm{~m} / \mathrm{sec}$, and in some cases in excess of $3.00 \mathrm{~m} / \mathrm{sec}$. Disturbance of the same surfaces (by repeated passage of a pickup truck) reduced the entrainment thresholds to $21-27 \%$ of the undisturbed values.

\section{RELATIONS BETWEEN ENTRAINMENT THRESHOLDS AND WIND PROFILE DATA}

It is possible to determine the frequency with which the natural winds in an area exceed the bare ground threshold entrainment wind shear velocity by comparing the wind tunnel and wind profile data. At no time in the experiment period did wind shear velocities at the Gate, Bedrock, or Joshua sites exceed entrainment thresholds. Figure 14 shows the relation between the wind shear velocities measured at the $10-\mathrm{m}$ mast at the Area 6 site and threshold values determined using the wind tunnel for key disturbed sites in Area 6. This graph shows that bare ground entrainment
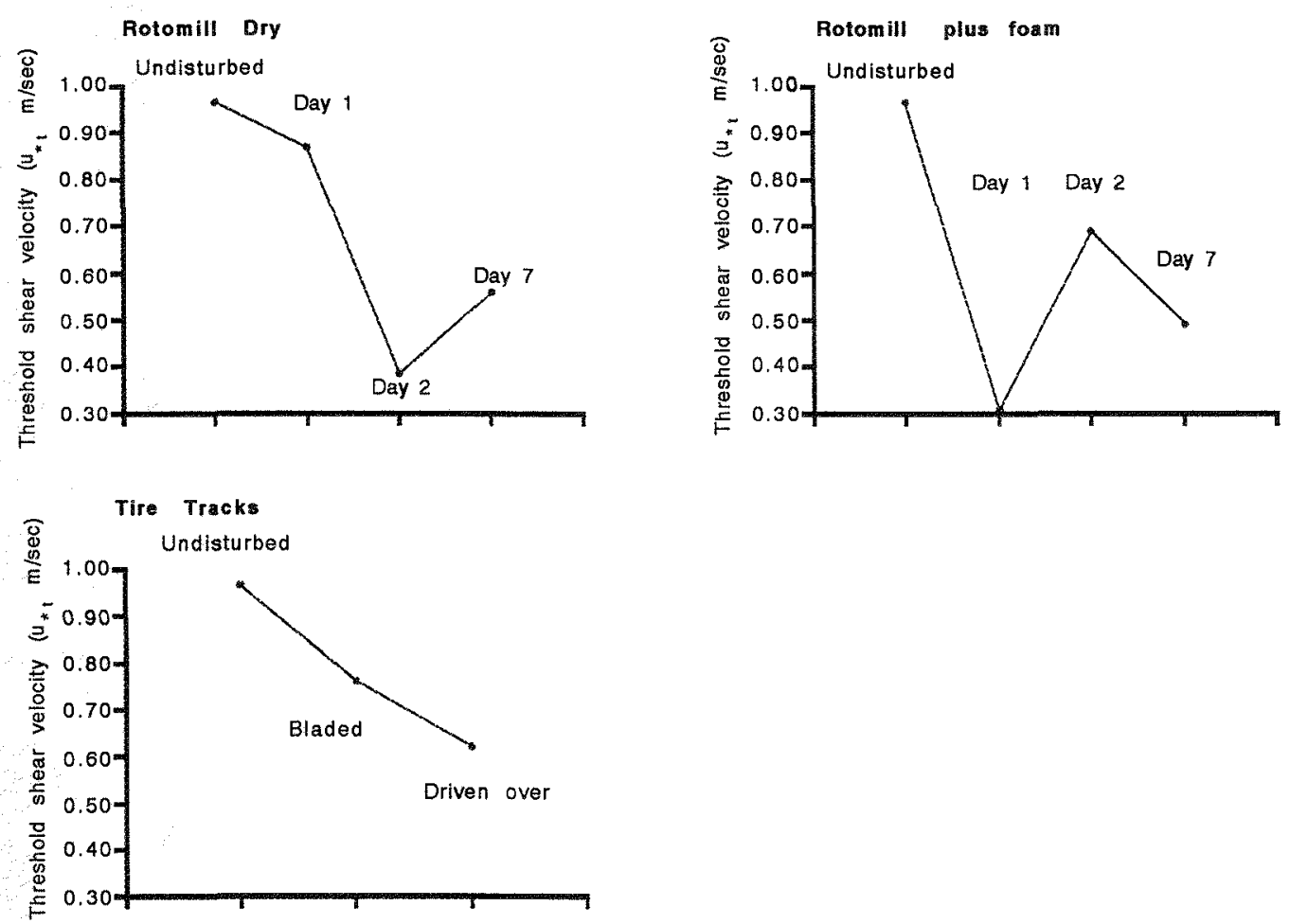

Figure 13. Changes in threshold wind shear velocity with time for disturbed sites. 
thresholds were generally not exceeded by the winds of the area during the period June 24 - July 19 , 1994, except for one treatment of the surface. This period does not, however, include the time of maximum winds in the area (April to June) and disturbance of the surface has the potential to make it possible for naturally occurring winds to entrain materials from these surfaces.

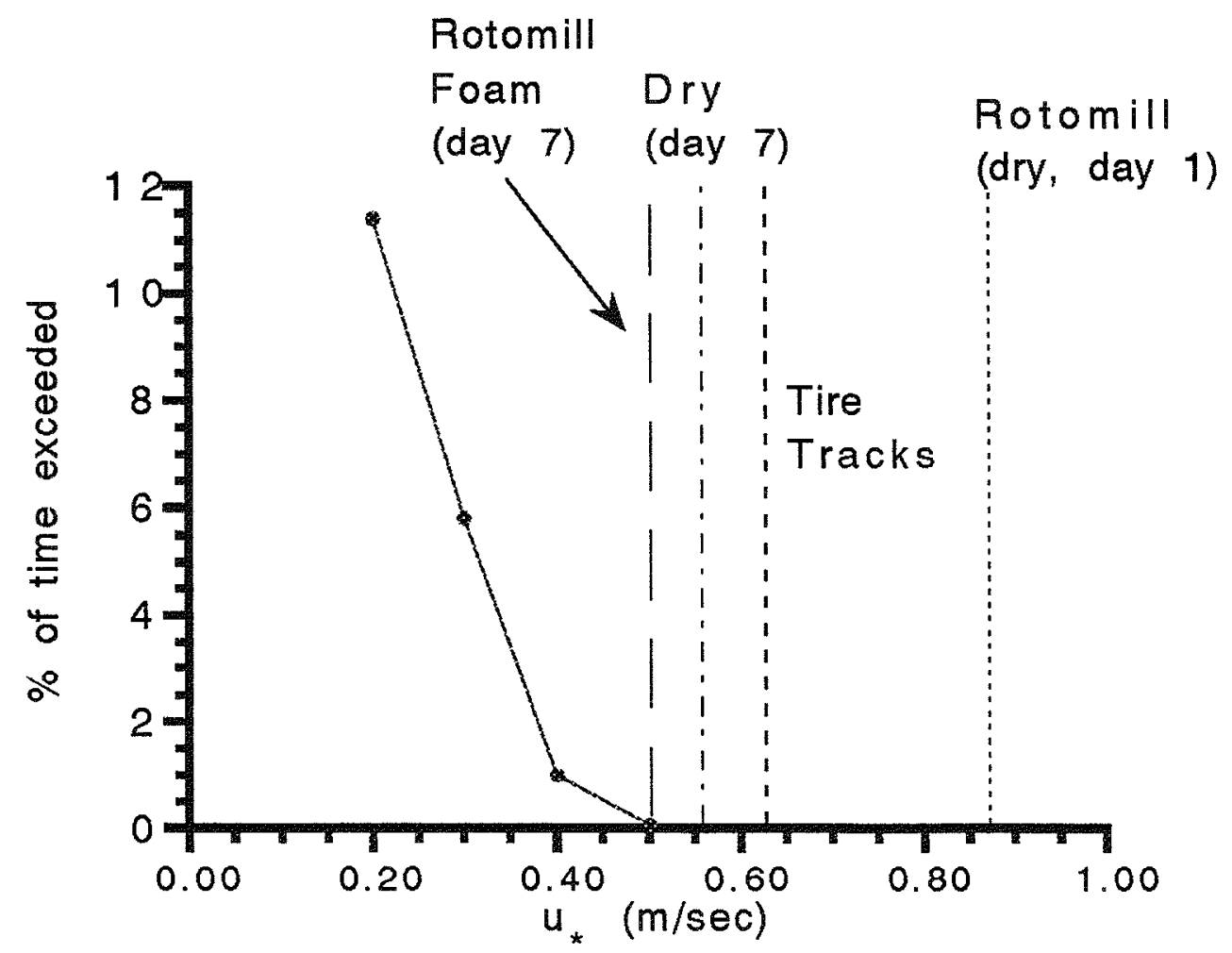

Figure 14. Percentage of the time wind shear velocities, as measured at the Area $610-\mathrm{m}$ mast, exceeded selected values during the period June 24 - July 19, 1994. Vertical lines indicate threshold wind shear velocity values determined from wind tunnel tests.

\section{CONCLUSIONS AND MANAGEMENT IMPLICATIONS}

Studies of wind profiles and vegetation cover in 1994 added to the data set, but failed to provide any significant data on the effect of annual changes in vegetation cover on winds and entrainment thresholds. It is probable that (1) our sample was too small and (2) the changes that did occur were not large enough (except at Gate) to have any major effects on the wind profile parameters.

By contrast, the wind tunnel studies provided important new data. They demonstrated that natural surfaces in the investigated areas of the Nevada Test Site are stable except at very high wind speeds (probably higher than normally occur, except perhaps in dust devils). However, disturbance of silty-clay surfaces by excavation devices and vehicles reduces the entrainment threshold by approximately $50 \%$ and makes these areas potentially very susceptible to wind erosion and transport of sediments, as originally demonstrated by Shinn and Homan (1987) and Shinn et al. (1989). 
This has some clear management implications for remediation of contaminated areas. Passage of all types of vehicles will result in destabilization of surfaces and enhanced emission of fine particles. Consequently, to minimize the possibility of wind transport of contaminated materials (including plutonium of respirable size), attention must be given to (1) immediate stabilization of excavated areas and (2) restriction of vehicular traffic to closely defined routes, which should be stabilized between passage of vehicles (e.g., by watering) and more permanently protected by mulches or polymers once activities in the area have ceased.

\section{ACKNOWLEDGMENTS}

We thank Larry Sheetz for building the wind tunnel and many other forms of help and advice, Frosty Miller and Rich McArthur for site photographs, Ken Allstead for assistance with vegetation species identifications, and Rich McArthur for guidance on site locations.

\section{REFERENCES CITED}

Bagnold, R.A., 1941, The Physics of Blown Sand and Desert Dunes. London, Chapman and Hall, 265 pp.

Bauer, B.O., D.J. Sherman and J.F. Wolcott, 1992, Sources of Uncertainty in Shear Stress and Roughness Length Estimates Derived from Velocity Profiles. Professional Geographer, v. 44, P. 453- 464.

Belly, Y., 1964, Sand Movement by Wind. U.S. Army Corps of Engineers, Coastal Engineering Research Center, Technical Memo, v. 1, Addendum III, 24 pp.

Chepil, W.S. and N.P. Woodruff, 1963, The Physics of Wind Erosion and its Control. Advances In Agronomy, v. 15, p. 211-302.

Garratt, J.R., 1992, The Atmospheric Boundary Layer. Cambridge University Press, Cambridge, New York, $316 \mathrm{p}$.

Gillette, D., 1978, Tests with a Portable Wind Tunnel for Determining Wind Erosion Threshold Velocities. Atmospheric Environment, v. 12, p. 2309-2313.

Gillette, D.A., J. Adams, A. Endo and D. Smith, 1980, Threshold Velocities for the Input of Soil Particles into the Air by Desert Soils. Journal of Geophysical Research, v. 85, p. 5621-5630.

Gillette, D.A., J. Adams, D. Muhs and R. Kihl, 1982, Threshold Friction Velocities and Rupture Moduli for Crusted Desert Soils for the Input of Soil Particles in the Air. Journal of Geophysical Research, v. 87, p. 9003-9015.

Gillette, D.A. and R. Passi, 1988, Modelling Dust Emission Caused by Wind Erosion. Journal of Geophysical Research, v. 93, p. 14,233-14,242.

Greeley, R., J.D. Iversen, J.B. Pollack, N. Udovich and B.R. White, 1974, Wind Tunnel Studies of Martian Aeolian Processes. Proceedings of the Royal Society of London, v. 341, P. 331-360.

Lancaster, N. and R. Bamford, 1994, Field Measurements for Boundary Layer Winds and Vegetation Cover at Sites in Area 11, Nevada Test Site, unpublished report for the Department of Energy, Nevada Operations Office, Nevada. 
Lancaster, N., K.R. Rasmussen and R. Greeley, 1991, Interactions Between Unvegetated Desert Surfaces and the Atmospheric Boundary Layer: A Preliminary Assessment. Acta Mechanica, Supplementum 2, p. 89-102.

Logie, M., 1982, Influence of Roughness Elements and Soil Moisture of Sand to Wind Erosion. Catena Supplement, v. 1, p. 161-173.

Lyles, L., R.L. Schrandt and N.F. Schneidler, 1974, How Aerodynamic Roughness Elements Control Sand Movement. Transactions American Society of Agricultural Engineers, v. 17, p. 134-139.

Marshall, J.K., 1971, Drag Measurements in Roughness Arrays of Varying Densities and Distribution. Agricultural Meteorology, v. 8, P. 269-292.

Musick, H.B. and D.A. Gillette, 1990, Field Evaluation of Relationships Between a Vegetation Structural Parameter and Sheltering Against Wind Erosion. Land Degradation and Rehabilitation, v. 2, p. 87-94.

Nickling, W.G., 1984, The Stabilizing Role of Bonding Agents on the Entrainment of Sediment by Wind. Sedimentology, v. 31, p. 111-117.

Nickling, W.G. and M. Ecclestone, 1981, The Effects of Soluble Salts on the Threshold Shear Velocity of Fine Sand. Sedimentology, v. 28, p. 505-510.

Raupach, M.R., D.A. Gillette and J.F. Leys, 1993, The Effect of Roughness Elements on Wind Erosion Threshold. Journal of Geophysical Research, v. 98, p. 3023-3029.

Shinn, J.H. and D.N. Homan, 1987, Plutonium-aerosol emission rates and human pulmonary deposition calculations for nuclear site 201, Nevada Test Site. In W.A. Howard and R.G. Fuller, eds., The Dynamics of Transuranics and other Radionuclides in Natural Environments: Las Vegas, NV, Department of Energy, Nevada Operations Office, NVO-272, p. 261-278.

Shinn, J.H., E.H. Essington, F.L. Miller, Jr., T.P. O’Farrell, J.A. Orcutt, E.M. Romney, J.W. Shugart and E.R. Sorom, 1989, Results of a cleanup and treatment test at the Nevada Test Site: evaluation of vacuum removal of Pu-contaminated soil. Health Physics, v. 57, no. 5, p. 771-779.

White, B.R., 1979, Soil Transport by Winds on Mars. Journal of Geophysical Research, v. 84, p. 4643-5651.

Wolfe, S.A. and W.G. Nickling, 1993, The Protective Role of Sparse Vegetation in Wind Erosion. Progress in Physical Geography, v. 17, p. 50-68.

Wolfe, S.A., 1993, Sparse vegetation as a surface control on wind erosion (Ph.D. thesis): University of Guelph.

Wooding, R.A., E.F. Bradley and J.K. Marshall, 1973, Drag Due to Regular Arrays of Roughness Elements of Varying Geometry. Boundary Layer Meteorology, v. 5, p. 285-308. 
APPENDIX 1

WIND PROFILE DATA 
Wind speeds $(\mathrm{m} / \mathrm{sec})$

Date Time $\quad 1.0 \mathrm{~m} \quad 1.78 \mathrm{~m} \quad 3.16 \mathrm{~m} \quad 5.62 \mathrm{~m} \quad 10.0 \mathrm{~m} \quad$ Azimuth $\mathrm{U}^{*} \quad$ Zo $\left(^{\circ}\right) \quad(\mathrm{m} / \mathrm{sec}) \quad(\mathrm{m})$

\begin{tabular}{|c|c|c|c|c|c|c|c|c|c|}
\hline 05-Jul & 1420 & 5.87 & 6.82 & 7.98 & 8.99 & 9.81 & 53 & 0.23 & 0.0349 \\
\hline 05-Jul & 1425 & 6.70 & 7.71 & 8.92 & 9.93 & 10.89 & 35 & 0.22 & 0.0265 \\
\hline 05-Jul & 1430 & 6.61 & 7.59 & 8.75 & 9.59 & 10.51 & 77 & 0.23 & 0.0203 \\
\hline 05-Jul & 1435 & 6.77 & 7.55 & 8.63 & 9.58 & 10.63 & 17 & 0.24 & 0.0195 \\
\hline $05-\mathrm{JuI}$ & 1440 & 6.21 & 7.06 & 8.05 & 8.89 & 9.60 & 93 & 0.27 & 0.0156 \\
\hline 05-Jul & 1445 & 6.71 & 7.63 & 8.69 & 9.59 & 10.45 & 49 & 0.24 & 0.0167 \\
\hline 05-Jul & 1450 & 6.81 & 7.64 & 8.67 & 9.53 & 10.41 & 25 & 0.25 & 0.0136 \\
\hline 05-Jul & 1455 & 6.36 & 7.17 & 8.23 & 9.03 & 9.96 & 19 & 0.25 & 0.0179 \\
\hline 05-Jul & 1500 & 6.52 & 7.45 & 8.45 & 9.35 & 10.11 & 60 & 0.25 & 0.0160 \\
\hline 05-Jul & 1505 & 6.72 & 7.57 & 8.61 & 9.53 & 10.29 & 65 & 0.25 & 0.0145 \\
\hline 05-Jul & 1515 & 6.59 & 7.46 & 8.40 & 9.44 & 10.29 & 25 & 0.25 & 0.0179 \\
\hline 05-Jul & 1525 & 6.46 & 7.37 & 8.52 & 9.48 & 10.35 & 322 & 0.23 & 0.0236 \\
\hline 05-Jul & 1540 & 6.71 & 7.54 & 8.49 & 9.40 & 10.29 & 9 & 0.26 & 0.0141 \\
\hline 05-Jul & 1545 & 6.92 & 7.81 & 9.03 & 10.06 & 11.21 & 299 & 0.21 & 0.0267 \\
\hline 05-Jul & 1550 & 6.91 & 7.79 & 8.97 & 10.14 & 11.19 & 278 & 0.21 & 0.0277 \\
\hline 05-Jul & 1555 & 6.84 & 7.67 & 8.84 & 9.86 & 10.74 & 302 & 0.23 & 0.0203 \\
\hline $05-\mathrm{Jul}$ & 1610 & 6.73 & 7.63 & 8.79 & 9.74 & 10.61 & 302 & 0.23 & 0.0200 \\
\hline $05-\mathrm{Jul}$ & 1615 & 6.60 & 7.49 & 8.69 & 9.61 & 10.57 & 279 & 0.23 & 0.0235 \\
\hline 05-Jul & 1620 & 6.77 & 7.61 & 8.86 & 9.90 & 10.87 & 308 & 0.22 & 0.0255 \\
\hline 05-Jul & 1635 & 6.29 & 7.14 & 8.27 & 9.25 & 10.25 & 296 & 0.23 & 0.0281 \\
\hline 05-Jul & 1645 & 6.46 & 7.38 & 8.48 & 9.40 & 10.35 & 327 & 0.24 & 0.0224 \\
\hline 05-Jul & 1650 & 6.25 & 7.02 & 8.09 & 9.00 & 10.02 & 10 & 0.24 & 0.0243 \\
\hline 05-Jul & 1655 & 5.56 & 6.25 & 7.22 & 7.95 & 8.67 & 0 & 0.29 & 0.0183 \\
\hline 05-Jul & 1705 & 6.01 & 6.76 & 7.76 & 8.75 & 9.72 & 290 & 0.24 & 0.0268 \\
\hline 05-Jul & 1710 & 5.94 & 6.67 & 7.66 & 8.69 & 9.58 & 341 & 0.25 & 0.0273 \\
\hline 05-Jul & 1715 & 5.75 & 6.52 & 7.61 & 8.54 & 9.48 & 287 & 0.24 & 0.0321 \\
\hline 05-Jul & 1720 & 6.76 & 7.65 & 8.88 & 10.00 & 11.00 & 291 & 0.21 & 0.0290 \\
\hline 05-Jul & 1735 & 6.33 & 7.21 & 8.39 & 9.56 & 10.57 & 263 & 0.21 & 0.0366 \\
\hline 05-Jul & 1740 & 5.63 & 6.42 & 7.45 & 8.40 & 9.21 & 307 & 0.25 & 0.0296 \\
\hline 05-Jul & 1745 & 5.44 & 6.23 & 7.30 & 8.27 & 9.17 & 331 & 0.24 & 0.0386 \\
\hline 05-Jul & 1755 & 4.73 & 5.43 & 6.32 & 7.18 & 7.90 & 348 & 0.28 & 0.0358 \\
\hline 05-Jul & 1800 & 5.38 & 6.16 & 7.09 & 7.92 & 8.64 & 68 & 0.28 & 0.0241 \\
\hline 05-Jul & 1805 & 5.11 & 5.85 & 6.74 & 7.60 & 8.48 & 308 & 0.27 & 0.0325 \\
\hline 05-Jul & 1810 & 5.85 & 6.67 & 7.81 & 8.84 & 9.80 & 257 & 0.23 & 0.0371 \\
\hline 05-Jul & 1815 & 5.29 & 6.01 & 6.95 & 7.82 & 8.69 & 352 & 0.27 & 0.0304 \\
\hline 05-Jul & 1820 & 5.54 & 6.32 & 7.24 & 8.16 & 9.02 & 347 & 0.26 & 0.0275 \\
\hline 05-Jul & 1825 & 5.30 & 6.02 & 7.05 & 8.02 & 8.86 & 297 & 0.25 & 0.0375 \\
\hline 05-Jul & 1830 & 5.16 & 5.88 & 6.76 & 7.74 & 8.55 & 5 & 0.27 & 0.0343 \\
\hline 05-Jul & 1835 & 5.42 & 6.24 & 7.18 & 8.07 & 8.98 & 1 & 0.26 & 0.0313 \\
\hline 05-Jul & 1840 & 5.00 & 5.70 & 6.47 & 7.32 & 8.30 & 19 & 0.28 & 0.0326 \\
\hline
\end{tabular}




\begin{tabular}{|c|c|c|c|c|c|c|c|c|c|}
\hline 05-Jul & 1900 & 5.02 & 5.79 & 6.76 & 7.78 & 8.73 & 270 & 0.24 & 0.0493 \\
\hline 05-Jul & 1905 & 4.87 & 5.64 & 6.65 & 7.51 & 8.17 & 254 & 0.27 & 0.0371 \\
\hline 05-Jul & 1910 & 5.14 & 5.87 & 6.89 & 7.92 & 8.91 & 290 & 0.24 & 0.0498 \\
\hline 05-Jul & 1920 & 4.87 & 5.61 & 6.70 & 7.67 & 8.56 & 249 & 0.24 & 0.0545 \\
\hline 05-Jul & 1925 & 4.58 & 5.26 & 6.20 & 7.10 & 7.94 & 265 & 0.27 & 0.0488 \\
\hline 05-Jul & 1930 & 4.60 & 5.27 & 6.19 & 6.97 & 7.68 & 246 & 0.29 & 0.0357 \\
\hline 05-Jul & 1935 & 4.84 & 5.52 & 6.49 & 7.37 & 8.21 & 271 & 0.27 & 0.0412 \\
\hline 05-Jul & 1940 & 4.40 & 5.01 & 5.87 & 6.74 & 7.60 & 221 & 0.28 & 0.0487 \\
\hline 05-Jul & 1945 & 4.63 & 5.28 & 6.29 & 7.27 & 8.20 & 188 & 0.25 & 0.0599 \\
\hline 05-Jul & 2010 & 4.33 & 5.02 & 5.96 & 6.95 & 7.90 & 208 & 0.25 & 0.0702 \\
\hline 05-Jul & 2020 & 4.10 & 4.70 & 5.66 & 6.55 & 7.36 & 220 & 0.27 & 0.0649 \\
\hline 05-Jul & 2025 & 4.09 & 4.66 & 5.44 & 6.37 & 7.13 & 224 & 0.29 & 0.0538 \\
\hline 06-Jul & 740 & 4.59 & 5.01 & 5.64 & 6.14 & 6.56 & 115 & 0.45 & 0.0057 \\
\hline 06-Jul & 750 & 4.97 & 5.38 & 6.07 & 6.72 & 7.31 & 128 & 0.38 & 0.0097 \\
\hline 06-Jul & 800 & 5.20 & 5.72 & 6.37 & 7.00 & 7.63 & 139 & 0.37 & 0.0081 \\
\hline 06-Jul & 805 & 5.28 & 5.80 & 6.49 & 7.24 & 7.87 & 153 & 0.35 & 0.0108 \\
\hline 06-Jul & 810 & 5.33 & 5.90 & 6.58 & 7.26 & 7.94 & 155 & 0.35 & 0.0098 \\
\hline 06-Jul & 815 & 5.78 & 6.43 & 7.13 & 7.72 & 8.23 & 158 & 0.37 & 0.0045 \\
\hline 06-Jul & 820 & 5.53 & 6.02 & 6.71 & 7.39 & 8.05 & 121 & 0.36 & 0.0076 \\
\hline 06-Jul & 835 & 5.48 & 5.90 & 6.61 & 7.19 & 7.63 & 131 & 0.41 & 0.0038 \\
\hline 06-Jul & 840 & 5.07 & 5.55 & 6.03 & 6.52 & 6.85 & 149 & 0.51 & 0.0016 \\
\hline 06-Jul & 905 & 4.32 & 4.76 & 5.21 & 5.64 & 5.93 & 156 & 0.56 & 0.0024 \\
\hline 09-Jul & 1415 & 5.36 & 6.00 & 6.78 & 7.51 & 8.02 & 157 & 0.34 & 0.0111 \\
\hline 09-Jul & 1430 & 5.26 & 5.93 & 6.73 & 7.47 & 7.99 & 162 & 0.33 & 0.0134 \\
\hline 09-Jul & 1445 & 5.74 & 6.48 & 7.45 & 8.30 & 9.00 & 161 & 0.28 & 0.0195 \\
\hline 09-Jul & 1500 & 5.12 & 5.78 & 6.64 & 7.35 & 7.93 & 165 & 0.32 & 0.0170 \\
\hline 09-Jul & 1515 & 5.02 & 5.70 & 6.56 & 7.27 & 7.81 & 162 & 0.32 & 0.0179 \\
\hline 09-Jul & 1530 & 5.59 & 6.29 & 7.21 & 8.00 & 8.64 & 164 & 0.29 & 0.0167 \\
\hline 09-Jul & 1545 & 4.47 & 5.06 & 5.80 & 6.33 & 6.82 & 157 & 0.38 & 0.0135 \\
\hline 09-Jul & 1600 & 5.57 & 6.33 & 7.27 & 8.12 & 8.84 & 166 & 0.28 & 0.0216 \\
\hline 09-Jul & 1630 & 5.32 & 6.06 & 6.89 & 7.63 & 8.22 & 177 & 0.31 & 0.0155 \\
\hline 09-Jul & 1645 & 5.21 & 5.91 & 6.79 & 7.54 & 8.15 & 161 & 0.31 & 0.0187 \\
\hline 09-Jul & 1700 & 5.12 & 5.84 & 6.70 & 7.51 & 8.25 & 172 & 0.29 & 0.0250 \\
\hline 09-Jul & 1715 & 4.87 & 5.56 & 6.38 & 7.06 & 7.65 & 166 & 0.33 & 0.0186 \\
\hline 09-Jul & 1730 & 5.48 & 6.24 & 7.16 & 7.96 & 8.69 & 173 & 0.28 & 0.0211 \\
\hline 09-Jul & 1745 & 5.08 & 5.77 & 6.68 & 7.45 & 8.15 & 169 & 0.29 & 0.0241 \\
\hline 09-Jul & 1800 & 4.75 & 5.43 & 6.25 & 7.02 & 7.69 & 169 & 0.31 & 0.0261 \\
\hline 09-Jul & 1815 & 4.77 & 5.48 & 6.22 & 6.92 & 7.52 & 181 & 0.33 & 0.0188 \\
\hline 09-Jul & 1830 & 4.70 & 5.37 & 6.19 & 6.90 & 7.64 & 177 & 0.31 & 0.0265 \\
\hline 09-Jul & 1845 & 4.42 & 5.08 & 5.86 & 6.62 & 7.45 & 160 & 0.30 & 0.0372 \\
\hline 09-Jul & 1900 & 4.66 & 5.34 & 6.19 & 7.00 & 7.81 & 174 & 0.29 & 0.0356 \\
\hline 10-Jul & 1300 & 5.28 & 5.94 & 6.76 & 7.42 & 7.99 & 157 & 0.33 & 0.0124 \\
\hline 10-Jul & 1330 & 4.93 & 5.55 & 6.34 & 6.95 & 7.46 & 152 & 0.35 & 0.0126 \\
\hline 10 -Jul & 1445 & 4.58 & 5.12 & 5.83 & 6.38 & 6.80 & 134 & 0.40 & 0.0101 \\
\hline 10-Jul & 1500 & 4.79 & 5.38 & 6.10 & 6.70 & 7.15 & 154 & 0.38 & 0.0104 \\
\hline 10-Jul & 1515 & 4.80 & 5.47 & 6.14 & 6.75 & 7.26 & 176 & 0.37 & 0.0112 \\
\hline
\end{tabular}




\begin{tabular}{|c|c|c|c|c|c|c|c|c|c|}
\hline 10-Jul & 1700 & 4.26 & 4.84 & 5.55 & 6.12 & 6.54 & 162 & 0.41 & 0.0152 \\
\hline 12-Jul & 1630 & 5.35 & 6.08 & 6.86 & 7.53 & 8.05 & 183 & 0.34 & 0.0109 \\
\hline 12-Jul & 1645 & 4.11 & 4.69 & 5.33 & 5.83 & 6.28 & 173 & 0.42 & 0.0133 \\
\hline 12-Jul & 1700 & 4.55 & 5.20 & 5.92 & 6.56 & 7.03 & 174 & 0.44 & 0.0159 \\
\hline 12-Jul & 1715 & 4.02 & 4.59 & 5.22 & 5.70 & 6.11 & 185 & 0.43 & 0.0126 \\
\hline 12-Jul & 1730 & 4.52 & 5.12 & 5.89 & 6.58 & 7.12 & 172 & 0.34 & 0.0205 \\
\hline 12-Jul & 1815 & 4.47 & 5.17 & 5.84 & 6.53 & 7.00 & 207 & 0.36 & 0.0179 \\
\hline 13-Jul & 1615 & 4.22 & 4.79 & 5.51 & 6.09 & 6.62 & 147 & 0.38 & 0.0187 \\
\hline 13-Jul & 1645 & 4.44 & 5.04 & 5.75 & 6.35 & 6.79 & 170 & 0.38 & 0.0144 \\
\hline 13-Jul & 1700 & 4.49 & 5.10 & 5.82 & 6.36 & 6.87 & 163 & 0.38 & 0.0136 \\
\hline 13-Jul & 1745 & 4.18 & 4.77 & 5.48 & 6.14 & 6.62 & 164 & 0.37 & 0.0216 \\
\hline 13-Jul & 1800 & 4.37 & 4.99 & 5.76 & 6.41 & 7.04 & 168 & 0.34 & 0.0247 \\
\hline 13-Jul & 1815 & 4.05 & 4.67 & 5.27 & 5.84 & 6.22 & 191 & 0.42 & 0.0141 \\
\hline $13-\mathrm{Jul}$ & 1830 & 4.21 & 4.81 & 5.57 & 6.17 & 6.70 & 171 & 0.36 & 0.0223 \\
\hline 14-Jul & 1545 & 4.86 & 5.44 & 6.16 & 6.70 & 7.16 & 163 & 0.39 & 0.0086 \\
\hline 14-Jul & 1615 & 4.82 & 5.46 & 6.22 & 6.78 & 7.27 & 169 & 0.37 & 0.0115 \\
\hline 14-Jul & 1630 & 4.78 & 5.37 & 6.13 & 6.76 & 7.21 & 164 & 0.37 & 0.0124 \\
\hline 14-Jul & 1645 & 5.09 & 5.78 & 6.59 & 7.30 & 7.81 & 172 & 0.33 & 0.0150 \\
\hline 14-Jul & 1700 & 4.27 & 4.83 & 5.49 & 6.00 & 6.40 & 171 & 0.42 & 0.0108 \\
\hline 14-Jul & 1715 & 4.93 & 5.56 & 6.41 & 7.09 & 7.71 & 166 & 0.32 & 0.0188 \\
\hline 14-Jul & 1730 & 4.45 & 5.07 & 5.79 & 6.36 & 6.81 & 168 & 0.38 & 0.0139 \\
\hline 14-Jul & 1745 & 4.50 & 5.12 & 5.93 & 6.55 & 7.06 & 171 & 0.35 & 0.0192 \\
\hline 14-Jul & 1800 & 4.69 & 5.38 & 6.23 & 7.00 & 7.62 & 168 & 0.31 & 0.0276 \\
\hline 14-Jul & 1815 & 4.83 & 5.50 & 6.30 & 7.00 & 7.60 & 176 & 0.33 & 0.0193 \\
\hline 14-Jul & 1830 & 4.72 & 5.40 & 6.31 & 7.12 & 7.80 & 166 & 0.29 & 0.0326 \\
\hline 14-Jul & 1845 & 4.44 & 5.09 & 5.95 & 6.82 & 7.52 & 167 & 0.29 & 0.0411 \\
\hline 14-Jul & 1900 & 4.34 & 4.97 & 5.78 & 6.58 & 7.30 & 171 & 0.31 & 0.0379 \\
\hline 14-Jul & 1915 & 4.00 & 4.65 & 5.50 & 6.26 & 6.95 & 171 & 0.31 & 0.0478 \\
\hline 14-Jul & 1930 & 4.26 & 4.91 & 5.77 & 6.61 & 7.40 & 173 & 0.29 & 0.0493 \\
\hline 15-Jul & 1615 & 4.12 & 4.65 & 5.33 & 5.88 & 6.28 & 166 & 0.41 & 0.0141 \\
\hline 15-Jul & 1715 & 4.73 & 5.39 & 6.15 & 6.79 & 7.31 & 183 & 0.35 & 0.0156 \\
\hline 15-Jul & 1730 & 4.54 & 5.18 & 5.90 & 6.54 & 7.14 & 175 & 0.35 & 0.0186 \\
\hline 15-Jul & 1745 & 4.94 & 5.64 & 6.51 & 7.27 & 7.99 & 176 & 0.30 & 0.0259 \\
\hline 15-Jul & 1800 & 4.93 & 5.63 & 6.57 & 7.39 & 8.05 & 169 & 0.29 & 0.0297 \\
\hline 15-Jul & 1815 & 4.54 & 5.16 & 5.97 & 6.77 & 7.42 & 170 & 0.31 & 0.0305 \\
\hline 15-Jul & 1830 & 4.38 & 5.02 & 5.84 & 6.64 & 7.43 & 168 & 0.30 & 0.0401 \\
\hline 15-Jul & 1845 & 4.60 & 5.24 & 6.07 & 6.85 & 7.54 & 163 & 0.31 & 0.0304 \\
\hline 15-Jul & 1900 & 4.29 & 4.87 & 5.68 & 6.42 & 7.12 & 167 & 0.32 & 0.0347 \\
\hline 16-Jul & 1430 & 4.13 & 4.67 & 5.31 & 5.84 & 6.25 & 187 & 0.42 & 0.0125 \\
\hline 16-Jul & 1545 & 4.32 & 4.95 & 5.68 & 6.30 & 6.76 & 171 & 0.37 & 0.0184 \\
\hline 16-Jul & 1615 & 4.66 & 5.31 & 6.07 & 6.65 & 7.14 & 184 & 0.36 & 0.0140 \\
\hline 16-Jul & 1715 & 4.94 & 5.62 & 6.47 & 7.22 & 7.93 & 167 & 0.30 & 0.0240 \\
\hline 16-Jul & 1730 & 4.37 & 4.94 & 5.80 & 6.49 & 7.13 & 159 & 0.32 & 0.0298 \\
\hline 16-Jul & 1745 & 5.01 & 5.67 & 6.58 & 7.36 & 8.11 & 155 & 0.29 & 0.0270 \\
\hline 16-Jul & 1800 & 4.68 & 5.34 & 6.22 & 6.98 & 7.69 & 172 & 0.30 & 0.0304 \\
\hline 16-Jul & 1815 & 4.42 & 5.02 & 5.83 & 6.54 & 7.26 & 167 & 0.32 & 0.0303 \\
\hline
\end{tabular}




$\begin{array}{lllllrrrrr}\text { 18-Jul } & 1115 & 4.41 & 4.96 & 5.74 & 6.30 & 6.75 & 121 & 0.38 & 0.0153 \\ \text { 18-Jul } & 1330 & 5.45 & 6.11 & 6.94 & 7.56 & 8.15 & 162 & 0.33 & 0.0104 \\ \text { 18-Jul } & 1445 & 4.62 & 5.19 & 5.90 & 6.44 & 6.86 & 168 & 0.40 & 0.0098 \\ \text { 18-Jul } & 1745 & 4.13 & 4.74 & 5.41 & 5.95 & 6.39 & 180 & 0.40 & 0.0155 \\ \text { 18-Jul } & 1900 & 4.83 & 5.56 & 6.25 & 6.97 & 7.60 & 250 & 0.33 & 0.0181 \\ \text { 18-Jul } & 1930 & 5.02 & 5.71 & 6.45 & 7.11 & 7.69 & 232 & 0.34 & 0.0137 \\ \text { 18-Jul } & 1945 & 5.10 & 5.83 & 6.61 & 7.52 & 8.30 & 223 & 0.28 & 0.0278 \\ \text { 18-Jul } & 2000 & 4.14 & 4.80 & 5.49 & 6.23 & 6.79 & 214 & 0.34 & 0.0290 \\ \text { 18-Jul } & 2030 & 4.07 & 4.74 & 5.51 & 6.17 & 6.72 & 137 & 0.34 & 0.0303 \\ \text { 18-Jul } & 2045 & 7.16 & 8.24 & 9.51 & 10.71 & 11.66 & 53 & 0.20 & 0.0278 \\ \text { 18-Jul } & 2100 & 4.74 & 5.52 & 6.41 & 7.21 & 7.87 & 62 & 0.29 & 0.0323 \\ \text { 18-Jul } & 2215 & 4.00 & 4.59 & 5.41 & 6.16 & 6.69 & 106 & 0.33 & 0.0378 \\ \text { 18-Jul } & 2300 & 4.37 & 4.96 & 5.89 & 6.79 & 7.46 & 133 & 0.29 & 0.0469 \\ & & & & & & \text { arithmetic mean } & 0.31 & 0.0242 \\ & & & & & & & \text { standard deviation } & 0.06 & 0.0128 \\ & & & & & & & \text { geometric mean } & 0.30 & 0.0208\end{array}$


Bedrock

Wind speeds $(\mathrm{m} / \mathrm{sec})$

Date Time $\quad 1.0 \mathrm{~m} \quad 1.78 \mathrm{~m} \quad 3.16 \mathrm{~m} \quad 5.62 \mathrm{~m} \quad 10.0 \mathrm{~m}$ Azimuth $\mathrm{U}^{*} \quad \mathrm{Zo}$

$\left(^{\circ}\right) \quad(\mathrm{m} / \mathrm{sec}) \quad(\mathrm{m})$

\begin{tabular}{llllllllll}
\hline 15-Jul & 1615 & 4.18 & 4.80 & 5.40 & 5.89 & 6.35 & 174 & 0.49 & 0.0310 \\
15-Jul & 1645 & 4.56 & 5.27 & 5.95 & 6.49 & 7.00 & 184 & 0.55 & 0.0346 \\
15-Jul & 1700 & 4.44 & 5.10 & 5.74 & 6.28 & 6.72 & 184 & 0.52 & 0.0308 \\
15-Jul & 1715 & 4.72 & 5.39 & 6.07 & 6.69 & 7.24 & 180 & 0.57 & 0.0353 \\
15-Jul & 1730 & 4.32 & 4.97 & 5.60 & 6.18 & 6.77 & 182 & 0.55 & 0.0416 \\
15-Jul & 1745 & 4.98 & 5.73 & 6.44 & 7.01 & 7.58 & 174 & 0.59 & 0.0316 \\
15-Jul & 1800 & 4.68 & 5.36 & 6.02 & 6.61 & 7.15 & 176 & 0.56 & 0.0338 \\
15-Jul & 1815 & 4.34 & 5.03 & 5.74 & 6.31 & 6.81 & 180 & 0.56 & 0.0437 \\
15-Jul & 1830 & 4.54 & 5.23 & 5.81 & 6.31 & 6.79 & 187 & 0.50 & 0.0252 \\
15-Jul & 1845 & 4.27 & 4.94 & 5.57 & 6.14 & 6.66 & 183 & 0.54 & 0.0404 \\
15-Jul & 1900 & 4.71 & 5.41 & 6.10 & 6.67 & 7.22 & 174 & 0.57 & 0.0345 \\
15-Jul & 1915 & 4.83 & 5.57 & 6.29 & 6.91 & 7.49 & 171 & 0.60 & 0.0381 \\
15-Jul & 1930 & 4.00 & 4.65 & 5.27 & 5.82 & 6.41 & 172 & 0.54 & 0.0495 \\
16-Jul & 1545 & 4.12 & 4.70 & 5.32 & 5.86 & 6.37 & 169 & 0.51 & 0.0382 \\
16-Jul & 1615 & 4.12 & 4.74 & 5.37 & 5.89 & 6.32 & 192 & 0.50 & 0.0360 \\
16-Jul & 1800 & 4.22 & 4.89 & 5.52 & 6.05 & 6.61 & 177 & 0.53 & 0.0406 \\
17-Jul & 1545 & 4.28 & 4.87 & 5.44 & 6.01 & 6.57 & 243 & 0.51 & 0.0351 \\
18-Jul & 2030 & 6.08 & 6.95 & 7.88 & 8.65 & 9.54 & 56 & 0.77 & 0.0426 \\
18-Jul & 2045 & 6.17 & 7.02 & 7.88 & 8.66 & 9.69 & 55 & 0.78 & 0.0423 \\
18-Jul & 2130 & 5.29 & 5.98 & 6.76 & 7.47 & 8.31 & 117 & 0.68 & 0.0444 \\
18-Jul & 2200 & 4.79 & 5.41 & 6.18 & 6.87 & 7.84 & 91 & 0.68 & 0.0626 \\
18-Jul & 2215 & 4.69 & 5.34 & 6.12 & 6.85 & 7.90 & 98 & 0.72 & 0.0764 \\
18-Jul & 2230 & 4.13 & 4.71 & 5.37 & 5.95 & 6.82 & 101 & 0.60 & 0.0653 \\
& & & & & & arithmetic mean & 0.58 & 0.0415 \\
& & & & & & standard deviation & 0.08 & 0.0120 \\
& & & & & & geometric mean & 0.58 & 0.0401
\end{tabular}


Gate

Wind speeds $(\mathrm{m} / \mathrm{sec})$

Date Time $\quad 1.0 \mathrm{~m} \quad 1.78 \mathrm{~m} \quad 3.16 \mathrm{~m} \quad 5.62 \mathrm{~m} \quad 10.0 \mathrm{~m} \quad$ Azimuth $\mathrm{U}^{*} \quad$ Zo

$\left({ }^{\circ}\right) \quad(\mathrm{m} / \mathrm{sec}) \quad(\mathrm{m})$

\begin{tabular}{|c|c|c|c|c|c|c|c|c|}
\hline 21-Jun & 1530 & 4.23 & 4.83 & 5.42 & 5.86 & 6.37 & No 0.48 & 0.0277 \\
\hline 21-Jun & 1630 & 4.04 & 4.64 & 5.17 & 5.60 & 6.08 & Data 0.45 & 0.0271 \\
\hline 21-Jun & 1645 & 4.42 & 5.04 & 5.62 & 6.06 & 6.57 & 0.48 & 0.0237 \\
\hline 22-Jun & 1145 & 5.02 & 5.69 & 6.35 & 6.91 & 7.48 & 0.55 & 0.0258 \\
\hline 22-Jun & 1200 & 4.16 & 4.71 & 5.30 & 5.76 & 6.25 & 0.47 & 0.0280 \\
\hline 22-Jun & 1215 & 4.78 & 5.41 & 6.06 & 6.55 & 7.06 & 0.51 & 0.0232 \\
\hline 22-Jun & 1230 & 4.87 & 5.53 & 6.21 & 6.75 & 7.32 & 0.55 & 0.0280 \\
\hline 22-Jun & 1245 & 4.90 & 5.56 & 6.25 & 6.79 & 7.36 & 0.55 & 0.0282 \\
\hline 22-Jun & 1300 & 4.60 & 5.24 & 5.90 & 6.43 & 6.90 & 0.52 & 0.0282 \\
\hline 22-Jun & 1315 & 4.78 & 5.41 & 6.07 & 6.58 & 7.15 & 0.53 & 0.0263 \\
\hline 22-Jun & 1345 & 4.79 & 5.45 & 6.09 & 6.61 & 7.13 & 0.53 & 0.0249 \\
\hline 22-Jun & 1400 & 5.19 & 5.90 & 6.58 & 7.17 & 7.74 & 0.57 & 0.0253 \\
\hline 22-Jun & 1415 & 4.44 & 5.05 & 5.64 & 6.08 & 6.50 & 0.47 & 0.0210 \\
\hline 22-Jun & 1430 & 5.24 & 5.95 & 6.67 & 7.20 & 7.75 & 0.57 & 0.0234 \\
\hline 22-Jun & 1445 & 4.20 & 4.87 & 5.49 & 5.93 & 6.43 & 0.50 & 0.0320 \\
\hline 22-Jun & 1500 & 5.11 & 5.78 & 6.45 & 6.97 & 7.57 & 0.55 & 0.0233 \\
\hline 22-Jun & 1515 & 4.47 & 5.08 & 5.69 & 6.20 & 6.69 & 0.50 & 0.0269 \\
\hline 22-Jun & 1530 & 4.98 & 5.64 & 6.27 & 6.81 & 7.38 & 0.54 & 0.0235 \\
\hline 22-Jun & 1545 & 4.67 & 5.30 & 5.92 & 6.49 & 7.06 & 0.53 & 0.0296 \\
\hline 22-Jun & 1600 & 4.80 & 5.46 & 6.09 & 6.59 & 7.12 & 0.52 & 0.0237 \\
\hline 22-Jun & 1615 & 4.40 & 5.02 & 5.60 & 6.05 & 6.51 & 0.48 & 0.0233 \\
\hline 22-Jun & 1630 & 4.12 & 4.69 & 5.25 & 5.67 & 6.11 & 0.45 & 0.0243 \\
\hline 22-Jun & 1645 & 5.02 & 5.72 & 6.34 & 6.88 & 7.50 & 0.55 & 0.0249 \\
\hline 22-Jun & 1715 & 4.61 & 5.30 & 5.98 & 6.55 & 7.12 & 0.56 & 0.0368 \\
\hline 22-Jun & 1730 & 4.59 & 5.32 & 6.01 & 6.60 & 7.21 & 0.59 & 0.0418 \\
\hline 22-Jun & 1745 & 4.63 & 5.32 & 6.00 & 6.59 & 7.18 & 0.57 & 0.0376 \\
\hline 22-Jun & 1800 & 4.77 & 5.47 & 6.14 & 6.73 & 7.37 & 0.58 & 0.0359 \\
\hline 22-Jun & 1815 & 4.46 & 5.11 & 5.67 & 6.19 & 6.82 & 0.52 & 0.0318 \\
\hline 22-Jun & 1830 & 4.19 & 4.81 & 5.45 & 5.97 & 6.49 & 0.52 & 0.0381 \\
\hline 22-Jun & 1845 & 4.54 & 5.22 & 5.87 & 6.48 & 7.08 & 0.57 & 0.0399 \\
\hline 23-Jun & 1130 & 4.17 & 4.76 & 5.36 & 5.85 & 6.26 & 0.48 & 0.0289 \\
\hline 23-Jun & 1145 & 4.24 & 4.87 & 5.46 & 5.94 & 6.37 & 0.48 & 0.0279 \\
\hline 23-Jun & 1200 & 4.22 & 4.81 & 5.43 & 5.89 & 6.34 & 0.48 & 0.0287 \\
\hline 23-Jun & 1215 & 4.82 & 5.45 & 6.12 & 6.61 & 7.11 & 0.52 & 0.0231 \\
\hline 23-Jun & 1245 & 4.64 & 5.26 & 5.85 & 6.30 & 6.76 & 0.48 & 0.0191 \\
\hline 23-Jun & 1300 & 4.35 & 4.94 & 5.58 & 6.05 & 6.60 & 0.50 & 0.0308 \\
\hline 23-Jun & 1315 & 4.80 & 5.41 & 6.04 & 6.58 & 7.11 & 0.52 & 0.0240 \\
\hline 23-Jun & 1330 & 4.75 & 5.37 & 6.03 & 6.52 & 7.05 & 0.52 & 0.0246 \\
\hline 23-Jun & 1345 & 4.83 & 5.53 & 6.20 & 6.78 & 7.33 & 0.56 & 0.0309 \\
\hline 23-Jun & 1400 & 4.87 & 5.53 & 6.22 & 6.78 & 7.27 & 0.55 & 0.0273 \\
\hline
\end{tabular}




\begin{tabular}{|c|c|c|c|c|c|c|c|c|}
\hline 23-Jun & 1415 & 5.11 & 5.78 & 6.49 & 7.05 & 7.61 & 0.57 & 0.0261 \\
\hline $23-$ Jun & 1430 & 4.70 & 5.36 & 6.00 & 6.50 & 7.00 & 0.52 & 0.0250 \\
\hline 23-Jun & 1445 & 4.40 & 4.98 & 5.60 & 6.09 & 6.52 & 0.48 & 0.0254 \\
\hline 23-Jun & 1515 & 5.12 & 5.81 & 6.49 & 7.07 & 7.69 & 0.57 & 0.0275 \\
\hline 23-Jun & 1530 & 4.55 & 5.19 & 5.83 & 6.35 & 6.87 & 0.52 & 0.0295 \\
\hline 23-Jun & 1545 & 4.91 & 5.57 & 6.22 & 6.76 & 7.26 & 0.53 & 0.0235 \\
\hline 23-Jun & 1600 & 4.11 & 4.69 & 5.29 & 5.74 & 6.19 & 0.47 & 0.0289 \\
\hline 23-Jun & 1615 & 4.52 & 5.15 & 5.80 & 6.35 & 6.85 & 0.53 & 0.0312 \\
\hline 23-Jun & 1700 & 4.28 & 4.95 & 5.55 & 6.04 & 6.50 & 0.50 & 0.0304 \\
\hline 23-Jun & 1730 & 4.05 & 4.66 & 5.25 & 5.73 & 6.19 & 0.48 & 0.0328 \\
\hline 23-Jun & 1800 & 4.39 & 5.02 & 5.63 & 6.19 & 6.76 & 0.53 & 0.0357 \\
\hline 24-Jun & 1415 & 4.05 & 4.63 & 5.22 & 5.71 & 6.12 & 0.47 & 0.0307 \\
\hline 24-Jun & 1430 & 4.78 & 5.43 & 6.09 & 6.64 & 7.22 & 0.55 & 0.0294 \\
\hline 24-Jun & 1445 & 4.51 & 5.13 & 5.71 & 6.22 & 6.66 & 0.49 & 0.0230 \\
\hline 24-Jun & 1500 & 4.57 & 5.18 & 5.81 & 6.32 & 6.76 & 0.50 & 0.0245 \\
\hline 24-Jun & 1515 & 4.96 & 5.64 & 6.29 & 6.86 & 7.54 & 0.57 & 0.0306 \\
\hline 24-Jun & 1530 & 4.05 & 4.60 & 5.12 & 5.54 & 6.01 & 0.44 & 0.0240 \\
\hline 24-Jun & 1545 & 4.62 & 5.24 & 5.83 & 6.34 & 6.91 & 0.51 & 0.0254 \\
\hline 24-Jun & 1600 & 4.11 & 4.67 & 5.23 & 5.71 & 6.15 & 0.46 & 0.0273 \\
\hline 24-Jun & 1615 & 4.24 & 4.89 & 5.49 & 6.00 & 6.48 & 0.50 & 0.0330 \\
\hline 24-Jun & 1630 & 4.51 & 5.15 & 5.78 & 6.37 & 6.98 & 0.55 & 0.0374 \\
\hline 24-Jun & 1645 & 4.15 & 4.75 & 5.31 & 5.77 & 6.24 & 0.47 & 0.0274 \\
\hline 24-Jun & 1700 & 4.51 & 5.20 & 5.80 & 6.31 & 6.87 & 0.52 & 0.0304 \\
\hline 24-Jun & 1715 & 4.15 & 4.80 & 5.39 & 5.86 & 6.31 & 0.48 & 0.0304 \\
\hline 24-Jun & 1730 & 4.24 & 4.88 & 5.45 & 5.96 & 6.47 & 0.50 & 0.0318 \\
\hline 24-Jun & 1745 & 4.12 & 4.72 & 5.27 & 5.73 & 6.23 & 0.47 & 0.0289 \\
\hline 24-Jun & 1815 & 4.38 & 5.03 & 5.63 & 6.16 & 6.71 & 0.52 & 0.0334 \\
\hline 25-Jun & 1015 & 4.11 & 4.65 & 5.21 & 5.64 & 6.04 & 0.44 & 0.0225 \\
\hline 25 -Jun & 1030 & 4.24 & 4.79 & 5.34 & 5.80 & 6.26 & 0.45 & 0.0229 \\
\hline 25-Jun & 1215 & 4.57 & 5.17 & 5.80 & 6.34 & 6.88 & 0.52 & 0.0291 \\
\hline 25-Jun & 1230 & 4.38 & 4.96 & 5.54 & 6.05 & 6.58 & 0.49 & 0.0281 \\
\hline 25-Jun & 1245 & 4.92 & 5.55 & 6.19 & 6.71 & 7.19 & 0.51 & 0.0206 \\
\hline 25-Jun & 1300 & 4.91 & 5.61 & 6.31 & 6.94 & 7.51 & 0.59 & 0.0340 \\
\hline 25-Jun & 1315 & 5.30 & 5.97 & 6.64 & 7.19 & 7.78 & 0.55 & 0.0210 \\
\hline 25-Jun & 1330 & 5.05 & 5.75 & 6.48 & 7.06 & 7.60 & 0.58 & 0.0289 \\
\hline 25-Jun & 1345 & 4.92 & 5.56 & 6.17 & 6.69 & 7.17 & 0.51 & 0.0198 \\
\hline 25-Jun & 1400 & 4.50 & 5.12 & 5.74 & 6.22 & 6.70 & 0.50 & 0.0254 \\
\hline 25-Jun & 1415 & 5.23 & 5.98 & 6.71 & 7.29 & 7.88 & 0.60 & 0.0284 \\
\hline 25-Jun & 1430 & 4.82 & 5.46 & 6.04 & 6.58 & 7.10 & 0.51 & 0.0220 \\
\hline 25-Jun & 1445 & 5.59 & 6.37 & 7.08 & 7.74 & 8.45 & 0.64 & 0.0291 \\
\hline 25-Jun & 1500 & 5.36 & 6.12 & 6.85 & 7.45 & 8.05 & 0.60 & 0.0271 \\
\hline 25-Jun & 1515 & 4.94 & 5.64 & 6.31 & 6.85 & 7.42 & 0.56 & 0.0275 \\
\hline 25-Jun & 1530 & 6.04 & 6.88 & 7.68 & 8.37 & 9.10 & 0.68 & 0.0281 \\
\hline 25-Jun & 1545 & 5.36 & 6.12 & 6.84 & 7.52 & 8.25 & 0.64 & 0.0352 \\
\hline 25-Jun & 1600 & 6.40 & 7.23 & 8.04 & 8.70 & 9.39 & 0.67 & 0.0212 \\
\hline 25-Jun & 1615 & 5.66 & 6.48 & 7.21 & 7.86 & 8.58 & 0.65 & 0.0294 \\
\hline
\end{tabular}




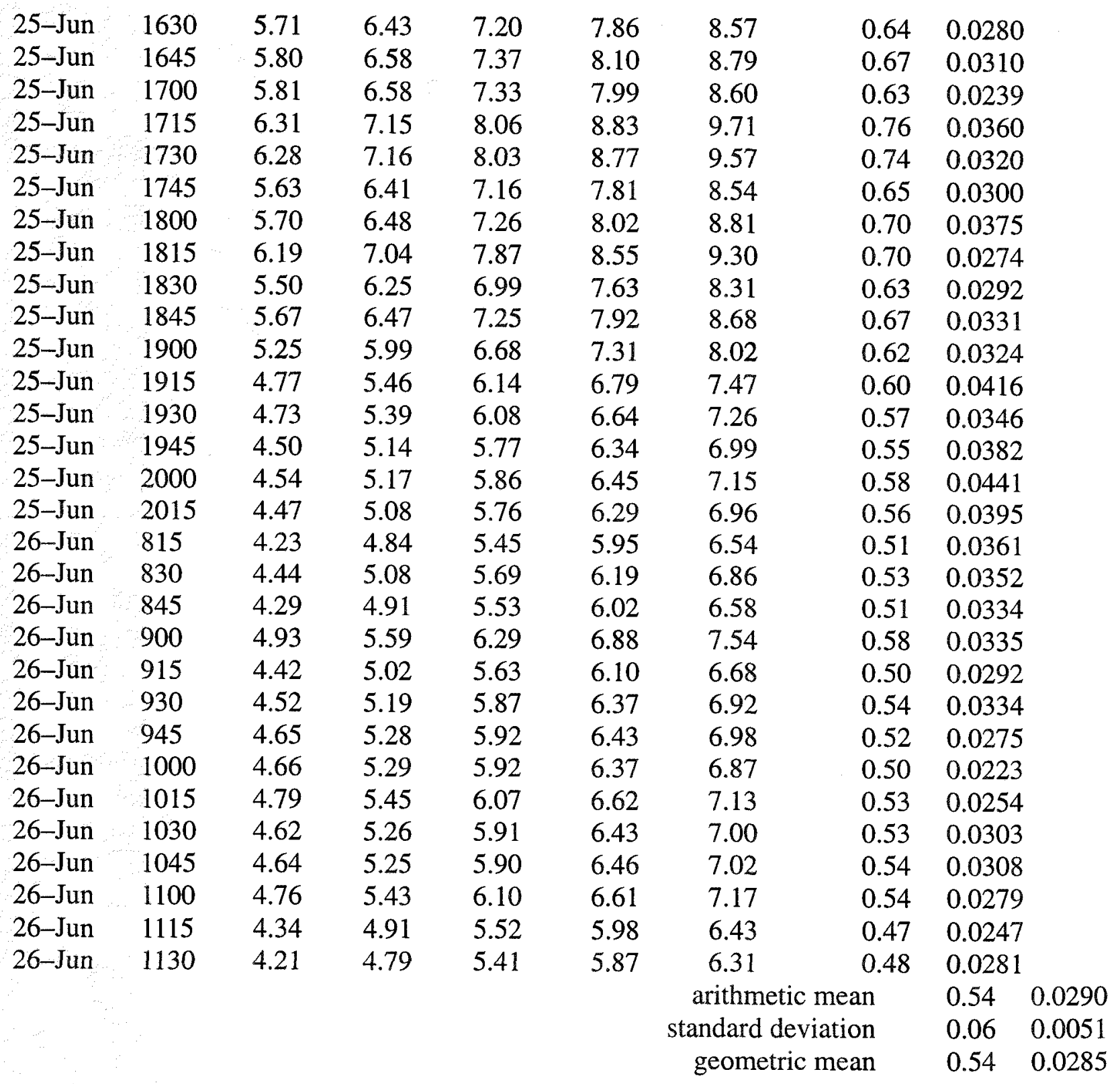


Wind speeds $(\mathrm{m} / \mathrm{sec})$

Date Time $\quad 1.0 \mathrm{~m} \quad 1.78 \mathrm{~m} \quad 3.16 \mathrm{~m} \quad 5.62 \mathrm{~m} \quad 10.0 \mathrm{~m} \quad$ Azimuth $\quad \mathrm{U}^{*} \quad$ Zo

$\left({ }^{\circ}\right) \quad(\mathrm{m} / \mathrm{sec}) \quad(\mathrm{m})$

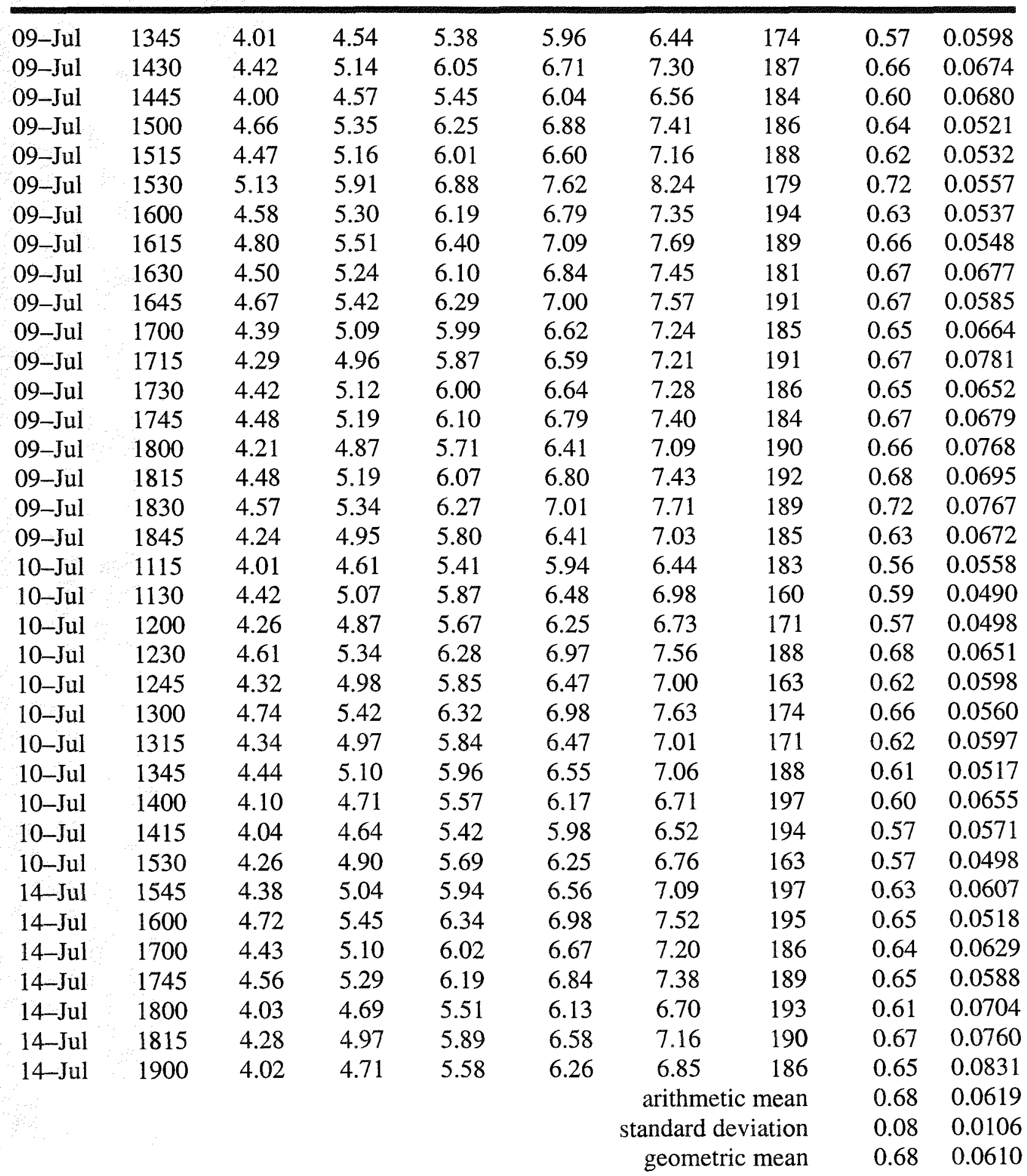




\section{APPENDIX 2}

\section{LATERAL COVER MEASUREMENTS}


Perennial Grasses / Forbs \& Groundcover $\left(\mathrm{L}_{\mathrm{c}}=.0112\right)$

Oryzopsis hymenoides

Oryzopsis hymenoides

Agropyron**

Perennial Shrubs

Sphaeralcea ambigua

Atriplex canescens

Chrysothamnus viscidiflorus

Grayia spinosa

Grayia spinosa

Atriplex confertifolia

Atriplex confertifolia

Eurotia lanata

Tetradymia glabrata

Tetradymia spinescens indian ricegrass

dead indian ricegrass

desert wheatgrass

$\left(\mathrm{L}_{\mathrm{c}}=.0066\right)$

desert mallow

fourwing saltbush

green rabbitbrush

spiny hopsage

dead spiny hopsage

shadscale

dead shadscale

winterfat

dead smooth horsebrush

spiny horsebrush
.0054

.0030

.0019

.0046

.0016

.0122

.0016

.0089

.0006

.0045

.0065

.0032

.0062

$.0004^{\circ}$

.1128

.0062
.0024

18.6

15.2

22.2

25.4

66.9

30.5

44.9

33.0

29.6

18.9

25.1

20.3

48.3

Annual Grasses / Forbs \& Groundcover $\left(\mathrm{L}_{\mathrm{c}}=.1256\right)$

Sitanion hystrix

Sitanion hystrix

Bromus tectorum

Machearanthera canescens

dead squirreltail

cheatgrass

$\left(\mathrm{L}_{\mathrm{c}}=.0007\right)$

Eriogonum spp.

Eriogonum inflatum

Salsola kali

russian thistle

dead russian thistle
12 Traces

1 Trace 
$\mathrm{L}_{\mathrm{c}} \quad$ Avg.Ht. (cm)

Perennial Grasses / Forbes \& Groundcover $\left(\mathrm{L}_{\mathrm{c}}=0\right)$

None

Perennial Shrubs

$$
\left(\mathrm{L}_{\mathrm{c}}=.0694\right)
$$

Sphaeralcea ambigua

Atriplex confertifolia

desert mallow

.0038

35.6

shadscale

.0256

34.0

Atriplex confertifolia

dead shadscale

.0012

spiny hopsage

.0303

dead spiny hopsage

.0022

winterfat

.0021

spiny horsebrush

.0022

dead spiny horsebrush

.0020

32.2

53.3

45.7

29.2

Tetradymia spinescens

Tetradymia spinescens

41.0

33.0

Annual Grasses / Forbes \& Groundcover $\left(\mathrm{L}_{\mathrm{c}}=.0693\right)$

Sitanion hystrix

Bromus tectorum

Machaeranthera canescens

Annual Shrubs $\left(\mathrm{L}_{\mathrm{c}}=0\right)$ squirreltail

cheatgrass
.0006

.0600

.0087
26.7

16.5

18.1

None 
Perennial Grasses / Forbs \& Groundcover $\left(\mathrm{L}_{\mathrm{c}}=0\right)$

Perennial Shrubs

$\left(\mathrm{L}_{\mathrm{c}}=.0138\right)$

Chrysothamus viscidiflorus Atriplex confertifolia

green rabbitbrush shadscale

$\left(\mathrm{L}_{\mathrm{c}}=.2452\right)$

Annual Grasses

Sitanion hystrix

Bromus tectorum

Annual Shrubs

Salsoli kali squirreltail cheatgrass

$\left(\mathrm{L}_{\mathrm{c}}=.0170\right)$

russian thistle
.0072

.0066

31.4

29.0

.0037

.2415

26.7

16.5

.0170

28.3 


$$
\text { Total } L_{c}=.2170
$$

$\mathrm{L}_{\mathrm{c}}$

Avg.Ht. (cm)

Perennial Grasses / Forbs \& Groundcover $\left(\mathrm{L}_{\mathrm{c}}=.0019\right)$

Oryzopsis hymenoides

indian ricegrass

.0019

Perennial Shrubs

$\left(\mathrm{L}_{\mathrm{c}}=.1425\right)$

Chrysothamnus viscidflorus

green rabbitbrush

.0353

shadscale $\quad .0135$

dead shadscale

.0023

23.4

Atriplex confertifolia

spiny hopsage

.0189

dead spiny hopsage

.0070

spiny horsebrush $\quad .0088$

Tetradymia spinescens

Cerotoides lanata

Ephedra Nevadensis

Ephedra Nevadensis winterfat

ephedra

dead ephedra

.0186

.0342

.0039

37.0

23.4

39.7

37.3

41.2

32.1

38.1

43.2

Annual Grasses / Forbs \& Groundcover $\left(\mathrm{L}_{\mathrm{c}}=.0635\right)$

Sitanion hystrix

Bromus Tectorum

indian ricegrass

.0018

cheatgrass

.0489

.0128

23.9

Machaeranthera canescens

$\left(\mathrm{L}_{\mathrm{c}}=.0091\right)$

Annual Shrubs

russian thistle

.0072

dead russian thistle

.0019

25.4

Salsola kali

22.9 
APPENDIX 3

WIND TUNNEL PROFILE DATA 
NTS 94 Wind Tunnel Data

Measurement in inches after site is bypass valve opening

Natural Surfaces

\section{Area 6}

Site 1, 3'

$\begin{array}{cccc}\text { Ht }(\mathrm{mm}) & \text { Test } 1(\mathrm{~m} / \mathrm{s}) & \text { Test } 2(\mathrm{~m} / \mathrm{s}) & \text { Test } 3(\mathrm{~m} / \mathrm{s}) \\ 5 & 2.21 & 3.14 & 3.14 \\ 10 & 4.68 & 5.21 & 4.96 \\ 15 & 5.54 & 5.87 & 5.87 \\ 20 & 5.76 & 6.84 & 6.77 \\ 25 & 6.98 & 7.36 & 7.19 \\ 30 & 7.58 & 7.85 & 7.69 \\ 35 & 7.90 & 7.94 & 8.25 \\ 40 & 8.26 & 8.31 & 8.60 \\ 45 & 8.49 & 8.82 & 9.02 \\ 50 & 8.91 & 9.02 & 9.10 \\ 55 & 9.10 & 9.50 & 9.23 \\ 60 & 9.10 & 9.68 & 9.55 \\ 65 & 9.49 & 9.55 & 9.55 \\ 70 & 9.57 & 9.80 & 9.75 \\ 75 & 9.70 & 9.80 & 9.88 \\ 80 & 9.75 & 9.93 & 10.00 \\ 85 & 9.57 & 9.88 & 9.93 \\ 90 & 9.62 & 9.75 & 10.00 \\ 95 & 9.49 & 9.68 & 9.93 \\ 100 & 9.70 & 9.75 & 9.93 \\ 105 & 9.62 & 9.88 & 9.88 \\ 110 & 9.37 & 9.62 & 9.80 \\ 115 & 9.23 & 9.50 & 9.62 \\ 120 & 9.18 & 9.36 & 9.55\end{array}$




\begin{tabular}{|c|c|c|c|c|}
\hline \multirow[t]{29}{*}{ Site 1, 6" } & $\begin{array}{c}\mathrm{Ht}(\mathrm{mm}) \\
0\end{array}$ & $\begin{array}{c}\text { Test } 1(\mathrm{~m} / \mathrm{s}) \\
3.16\end{array}$ & $\begin{array}{c}\text { Test } 2(\mathrm{~m} / \mathrm{s}) \\
3.53\end{array}$ & $\begin{array}{c}\text { Test } 3(\mathrm{~m} / \mathrm{s}) \\
3.87\end{array}$ \\
\hline & 5 & 3.39 & 4.05 & 3.87 \\
\hline & 10 & 3.87 & 4.63 & 4.46 \\
\hline & 15 & 4.89 & & \\
\hline & 20 & 5.38 & 5.47 & 5.47 \\
\hline & 25 & 5.82 & & \\
\hline & 30 & 6.11 & & \\
\hline & 35 & 6.43 & & \\
\hline & 40 & 6.81 & 6.88 & 7.06 \\
\hline & 45 & 6.99 & & \\
\hline & 50 & 7.16 & & \\
\hline & 55 & 7.34 & & \\
\hline & 60 & 7.40 & & \\
\hline & 65 & 7.73 & & \\
\hline & 70 & 7.73 & & \\
\hline & 75 & 7.73 & & \\
\hline & 80 & 7.73 & 7.73 & 8.05 \\
\hline & 85 & 7.83 & & \\
\hline & 90 & 7.67 & & \\
\hline & 95 & 7.67 & & \\
\hline & 100 & 7.67 & & \\
\hline & 105 & 7.57 & & \\
\hline & 110 & 7.50 & & \\
\hline & 115 & 7.34 & & \\
\hline & 120 & 7.34 & 7.16 & 7.40 \\
\hline & 125 & 7.06 & & \\
\hline & 130 & 6.88 & & \\
\hline & 135 & 6.70 & & \\
\hline & 140 & 6.62 & & \\
\hline
\end{tabular}

\begin{tabular}{|c|c|c|c|c|}
\hline \multirow[t]{13}{*}{ Site 2, 2"' } & $\mathrm{Ht}(\mathrm{mm})$ & Test $1(\mathrm{~m} / \mathrm{s})$ & $\begin{array}{l}\text { Test } 2(\mathrm{~m} / \mathrm{s}) \\
497\end{array}$ & Test $3(\mathrm{~m} / \mathrm{s})$ \\
\hline & 10 & $\begin{array}{l}5.11 \\
6.00\end{array}$ & $\begin{array}{l}4.91 \\
6.66\end{array}$ & $\begin{array}{l}5.12 \\
6.41\end{array}$ \\
\hline & 20 & 7.94 & 8.25 & 7.96 \\
\hline & 30 & 8.68 & 9.24 & 8.90 \\
\hline & 40 & 9.36 & 10.37 & 9.65 \\
\hline & 50 & 10.05 & 10.30 & 10.02 \\
\hline & 60 & 10.48 & 10.65 & 10.74 \\
\hline & 70 & 10.76 & 10.88 & 10.90 \\
\hline & 80 & 10.99 & 11.00 & 10.97 \\
\hline & 90 & 11.05 & 11.00 & 10.97 \\
\hline & 100 & 10.87 & 10.95 & 10.79 \\
\hline & 110 & 10.60 & 10.54 & 10.62 \\
\hline & 120 & 10.24 & 10.37 & 10.39 \\
\hline
\end{tabular}




\begin{tabular}{|c|c|c|c|c|}
\hline Site 2, 6"' & Ht $\frac{(\mathrm{mm})}{5}$ & $\begin{array}{c}\text { Test } 1(\mathrm{~m} / \mathrm{s}) \\
2.19\end{array}$ & $\begin{array}{c}\text { Test } 2(\mathrm{~m} / \mathrm{s}) \\
2.94\end{array}$ & $\begin{array}{c}\text { Test } 3(\mathrm{~m} / \mathrm{s}) \\
3.11\end{array}$ \\
\hline & 10 & 3.09 & 3.32 & 3.48 \\
\hline & 20 & 4.53 & 4.38 & 4.40 \\
\hline & 30 & 4.79 & 5.14 & 4.82 \\
\hline & 40 & 5.36 & 5.59 & 4.82 \\
\hline & 50 & 5.79 & 6.12 & 5.16 \\
\hline & 60 & 6.11 & 6.20 & 5.61 \\
\hline & 70 & 6.56 & 6.50 & 5.53 \\
\hline & 80 & 6.74 & 6.58 & 5.53 \\
\hline & 90 & 6.67 & 6.50 & 5.53 \\
\hline & 100 & 6.67 & 6.50 & 5.30 \\
\hline & 110 & 6.11 & 6.32 & 4.92 \\
\hline & 120 & 5.79 & 5.92 & 4.82 \\
\hline
\end{tabular}

Site 3, 2"

$\begin{array}{cccc}\text { Ht }(\mathrm{mm}) & \text { Test } 1(\mathrm{~m} / \mathrm{s}) & \text { Test } 2(\mathrm{~m} / \mathrm{s}) & \text { Test } 3(\mathrm{~m} / \mathrm{s}) \\ 5 & 3.57 & 3.58 & 3.58 \\ 10 & 5.30 & 5.06 & 5.54 \\ 20 & 7.25 & 6.78 & 7.33 \\ 30 & 8.54 & 8.25 & 8.70 \\ 40 & 9.26 & 9.05 & 9.54 \\ 50 & 9.67 & 9.80 & 9.80 \\ 60 & 10.05 & 9.99 & 10.36 \\ 70 & 10.55 & 10.44 & 10.61 \\ 80 & 10.79 & 10.44 & 10.61 \\ 90 & 10.79 & 10.61 & 10.73 \\ 100 & 10.67 & 10.68 & 10.61 \\ 110 & 10.79 & 10.56 & 10.49 \\ 120 & 10.79 & 10.44 & 10.56\end{array}$

Site 3, 6"

$\begin{array}{ccccc}\text { Ht }(\mathrm{mm}) & \text { Test } 1(\mathrm{~m} / \mathrm{s}) & \text { Test } 2(\mathrm{~m} / \mathrm{s}) & \text { Test } 3(\mathrm{~m} / \mathrm{s}) & \text { Test } 4(\mathrm{~m} / \mathrm{s}) \\ 5 & 2.01 & 2.02 & 2.02 & 1.60 \\ 10 & 2.75 & 3.02 & 2.57 & 2.58 \\ 20 & 3.41 & 3.77 & 3.42 & 3.78 \\ 30 & 4.08 & 4.39 & 3.56 & 4.52 \\ 40 & 4.77 & 5.04 & 4.09 & 5.21 \\ 50 & 5.02 & 5.43 & 5.04 & 5.54 \\ 60 & 5.17 & 5.66 & 5.19 & 5.54 \\ 70 & 5.64 & 5.88 & 5.19 & 5.54 \\ 80 & 5.86 & 5.88 & 5.43 & 5.54 \\ 90 & 5.50 & 5.96 & 5.52 & 5.77 \\ 100 & 5.17 & 5.96 & 5.52 & 5.77 \\ 110 & 5.41 & 5.88 & 5.66 & 5.68 \\ 120 & 4.92 & 5.52 & 5.66 & 5.45\end{array}$


Bedrock

Site $\mathbf{1 , 2 . 2 5}$

$\begin{array}{cccc}\text { Ht }(\mathrm{mm}) & \text { Test } 1(\mathrm{~m} / \mathrm{s}) & \text { Test } 2(\mathrm{~m} / \mathrm{s}) & \text { Test } 3(\mathrm{~m} / \mathrm{s}) \\ 5 & 3.58 & 4.11 & 3.92 \\ 10 & 4.53 & 4.80 & 4.53 \\ 20 & 5.77 & 5.98 & 5.90 \\ 30 & 6.90 & 7.26 & 6.98 \\ 40 & 7.94 & 8.25 & 7.77 \\ 50 & 8.47 & 8.99 & 8.85 \\ 60 & 9.28 & 9.73 & 9.81 \\ 70 & 10.07 & 10.44 & 10.07 \\ 80 & 10.74 & 11.15 & 10.97 \\ 90 & 10.97 & 11.42 & 11.32 \\ 100 & 11.20 & 11.42 & 11.54 \\ 110 & 11.32 & 11.19 & 11.43 \\ 120 & 11.43 & 11.15 & 11.27\end{array}$

Site 1, 4"

Ht $(\mathrm{mm})$
5
10
20
30
40
50
60
70
80
90
100
110
120

Test $1(\mathrm{~m} / \mathrm{s})$
3.43
3.92
4.95
5.90
6.40
6.90
7.43
8.46
8.55
9.27
9.41
9.32
9.13

$\begin{array}{cc}\text { Test } 2(\mathrm{~m} / \mathrm{s}) & \text { Test } 3(\mathrm{~m} / \mathrm{s}) \\ 3.20 & 3.20 \\ 3.78 & 3.58 \\ 4.52 & 4.69 \\ 5.45 & 5.68 \\ 5.45 & 6.19 \\ 6.71 & 6.78 \\ 7.60 & 7.67 \\ 8.25 & 8.31 \\ 8.76 & 8.55 \\ 8.76 & 9.19 \\ 8.85 & 9.19 \\ 8.90 & 8.76 \\ 8.99 & 8.55\end{array}$

Site 2, 2.5"

$\begin{array}{cccc}\text { Ht }(\mathrm{mm}) & \text { Test } 1(\mathrm{~m} / \mathrm{s}) & \text { Test } 2(\mathrm{~m} / \mathrm{s}) & \text { Test } 3(\mathrm{~m} / \mathrm{s}) \\ 5 & 5.22 & 5.22 & 5.23 \\ 10 & 6.30 & 6.22 & 6.03 \\ 20 & 7.55 & 7.55 & 7.73 \\ 30 & 8.57 & 8.48 & 8.64 \\ 40 & 8.99 & 9.26 & 9.41 \\ 50 & 9.39 & 9.83 & 10.05 \\ 60 & 10.44 & 10.40 & 10.70 \\ 70 & 10.91 & 10.91 & 11.04 \\ 80 & 11.13 & 11.09 & 11.22 \\ 90 & 11.24 & 11.35 & 11.04 \\ 100 & 10.91 & 11.09 & 10.93 \\ 110 & 10.68 & 10.56 & 10.58 \\ 120 & 10.20 & 10.20 & 10.34\end{array}$


Site 2, 6"

$\begin{array}{cccc}\text { Ht }(\mathrm{mm}) & \text { Test } 1(\mathrm{~m} / \mathrm{s}) & \text { Test } 2(\mathrm{~m} / \mathrm{s}) & \text { Test } 3(\mathrm{~m} / \mathrm{s}) \\ 5 & 2.71 & 3.14 & 2.98 \\ 10 & 3.50 & 3.71 & 3.52 \\ 20 & 4.14 & 4.70 & 4.33 \\ 30 & 4.70 & 4.70 & 4.61 \\ 40 & 5.33 & 5.43 & 4.97 \\ 50 & 5.56 & 5.87 & 5.58 \\ 60 & 5.98 & 6.19 & 5.88 \\ 70 & 6.38 & 6.47 & 5.88 \\ 80 & 6.57 & 6.47 & 6.21 \\ 90 & 6.57 & 6.65 & 6.29 \\ 100 & 6.46 & 6.47 & 6.40 \\ 110 & 6.57 & 6.47 & 6.29 \\ 120 & 6.38 & 6.27 & 6.21\end{array}$

Site 3, 2'

$\begin{array}{cccc}\text { Ht }(\mathrm{mm}) & \text { Test } 1(\mathrm{~m} / \mathrm{s}) & \text { Test } 2(\mathrm{~m} / \mathrm{s}) & \text { Test } 3(\mathrm{~m} / \mathrm{s}) \\ 5 & 5.02 & 5.26 & 4.08 \\ 10 & 5.93 & 6.27 & 5.41 \\ 20 & 7.54 & 7.10 & 7.10 \\ 30 & 8.48 & 8.09 & 8.41 \\ 40 & 9.25 & 8.78 & 9.21 \\ 50 & 9.72 & 9.12 & 10.17 \\ 60 & 10.16 & 10.04 & 10.37 \\ 70 & 10.28 & 10.41 & 10.54 \\ 80 & 10.52 & 10.60 & 10.29 \\ 90 & 10.76 & 10.41 & 10.61 \\ 100 & 10.87 & 10.41 & 10.37 \\ 110 & 10.28 & 10.16 & 10.49 \\ 120 & 10.23 & 9.91 & 10.05\end{array}$

$\begin{array}{ccccc}\text { Site 3, 2.5” } & \text { Ht }(\mathrm{mm}) & \text { Test } 1(\mathrm{~m} / \mathrm{s}) & \text { Test } 2(\mathrm{~m} / \mathrm{s}) & \text { Test } 3(\mathrm{~m} / \mathrm{s}) \\ 5 & 5.22 & 16.51 & 3.01 \\ 10 & 6.30 & 6.22 & 3.40 \\ 20 & 7.55 & 7.55 & 3.88 \\ 30 & 8.57 & 8.48 & 4.20 \\ 40 & 8.99 & 9.26 & 4.65 \\ 50 & 9.39 & 9.83 & 5.49 \\ 60 & 10.44 & 10.40 & 5.72 \\ 70 & 10.91 & 10.91 & 5.63 \\ 80 & 11.13 & 11.09 & 5.72 \\ 90 & 11.24 & 11.35 & 5.16 \\ 100 & 10.91 & 11.09 & 5.02 \\ 110 & 10.68 & 10.56 & 5.26 \\ 120 & 10.20 & 10.20 & 5.16\end{array}$




\begin{tabular}{|c|c|c|c|c|}
\hline Site 3, 6" & $\begin{array}{l}\mathrm{Ht}(\mathrm{mm}) \\
5\end{array}$ & $\begin{array}{l}\text { Test } 1(\mathrm{~m} / \mathrm{s}) \\
2.55\end{array}$ & $\begin{array}{c}\text { Test } 2(\mathrm{~m} / \mathrm{s}) \\
3.17\end{array}$ & $\begin{array}{c}\text { Test } 3(\mathrm{~m} / \mathrm{s}) \\
2.98\end{array}$ \\
\hline & 10 & 2.74 & 3.40 & 3.52 \\
\hline & 20 & 3.54 & 4.07 & 4.33 \\
\hline & 30 & 4.19 & 4.37 & 4.61 \\
\hline & 40 & 4.53 & 5.01 & 4.97 \\
\hline & 50 & 5.00 & 5.63 & 5.58 \\
\hline & 60 & 5.15 & 6.06 & 5.88 \\
\hline & 70 & 5.25 & 6.14 & 5.88 \\
\hline & 80 & 5.48 & 6.14 & 6.21 \\
\hline & 90 & 5.70 & 6.14 & 6.29 \\
\hline & 100 & 5.70 & 5.93 & 6.40 \\
\hline & 110 & 5.70 & 5.93 & 6.29 \\
\hline & 120 & 5.00 & 5.84 & 6.21 \\
\hline
\end{tabular}


Gate

Site 1, 2.5"

$\begin{array}{cccc}\text { Ht }(\mathrm{mm}) & \text { Test } 1(\mathrm{~m} / \mathrm{s}) & \text { Test } 2(\mathrm{~m} / \mathrm{s}) & \text { Test } 3(\mathrm{~m} / \mathrm{s}) \\ 5 & 3.86 & 3.74 & 5.00 \\ 10 & 4.99 & 4.47 & 5.83 \\ 20 & 6.87 & 6.32 & 7.08 \\ 30 & 7.50 & 7.41 & 7.75 \\ 40 & 7.82 & 8.06 & 7.91 \\ 50 & 7.73 & 7.84 & 8.01 \\ 60 & 7.98 & 7.84 & 7.91 \\ 70 & 8.19 & 8.06 & 8.16 \\ 80 & 8.92 & 8.80 & 9.09 \\ 90 & 9.41 & 9.30 & 9.44 \\ 100 & 9.85 & 9.95 & 9.83 \\ 110 & 10.34 & 10.37 & 10.37 \\ 120 & 10.77 & 10.60 & 10.73\end{array}$

Site 1, 6"

$\begin{array}{cccc}\text { Ht }(\mathrm{mm}) & \text { Test } 1(\mathrm{~m} / \mathrm{s}) & \text { Test } 2(\mathrm{~m} / \mathrm{s}) & \text { Test } 3(\mathrm{~m} / \mathrm{s}) \\ 5 & 0.00 & 1.57 & 1.57 \\ 10 & 1.99 & 2.22 & 2.53 \\ 20 & 2.98 & 3.72 & 3.37 \\ 30 & 3.72 & 4.04 & 3.37 \\ 40 & 3.85 & 4.16 & 4.33 \\ 50 & 3.85 & 4.16 & 4.16 \\ 60 & 4.04 & 4.61 & 4.45 \\ 70 & 4.16 & 4.61 & 4.72 \\ 80 & 4.61 & 5.22 & 4.87 \\ 90 & 5.12 & 5.58 & 5.35 \\ 100 & 5.45 & 5.80 & 5.35 \\ 110 & 6.01 & 6.09 & 5.67 \\ 120 & 6.09 & 6.21 & 5.88\end{array}$

$\begin{array}{lcccc}\text { Site 2, 1.5" } & \text { Ht }(\mathrm{mm}) & \text { Test 1 }(\mathrm{m} / \mathrm{s}) & \text { Test 2 (m/s) } & \text { Test 3 (m/s) } \\ \text { Entrainment } & 5 & 5.03 & 5.03 & 5.03 \\ & 10 & 6.56 & 6.36 & 6.36 \\ & 20 & 8.27 & 7.29 & 8.56 \\ & 30 & 9.68 & 7.96 & 9.41 \\ & 40 & 10.79 & 9.00 & 10.30 \\ 50 & 11.14 & 10.06 & 10.43 \\ & 60 & 11.91 & 11.02 & 11.01 \\ 70 & 12.01 & 11.47 & 11.57 \\ & 12.01 & 12.22 & 11.90 \\ & 90 & 12.32 & 12.83 & 12.11 \\ & 100 & 12.32 & 13.02 & 12.00 \\ & 110 & 12.63 & 12.83 & 12.00 \\ 120 & 12.22 & 12.43 & 11.46\end{array}$


Site 2, 3"

$\begin{array}{cccc}\text { Ht }(\mathrm{mm}) & \text { Test } 1(\mathrm{~m} / \mathrm{s}) & \text { Test } 2(\mathrm{~m} / \mathrm{s}) & \text { Test } 3(\mathrm{~m} / \mathrm{s}) \\ 5 & 4.20 & 3.89 & 3.55 \\ 10 & 5.27 & 5.03 & 4.49 \\ 20 & 6.55 & 6.16 & 5.50 \\ 30 & 6.92 & 6.16 & 6.54 \\ 40 & 7.28 & 8.11 & 7.27 \\ 50 & 8.25 & 8.41 & 7.94 \\ 60 & 8.84 & 8.56 & 8.55 \\ 70 & 9.79 & 9.13 & 9.65 \\ 80 & 9.40 & 9.67 & 9.91 \\ 90 & 9.66 & 9.80 & 9.65 \\ 100 & 9.40 & 9.80 & 9.78 \\ 110 & 9.26 & 10.06 & 9.65 \\ 120 & 9.13 & 9.54 & 9.65\end{array}$

Site 2, 6"

$\begin{array}{cccc}\text { Ht }(\mathrm{mm}) & \text { Test } 1(\mathrm{~m} / \mathrm{s}) & \text { Test } 2(\mathrm{~m} / \mathrm{s}) & \text { Test } 3(\mathrm{~m} / \mathrm{s}) \\ 5 & 2.56 & 2.56 & 2.75 \\ 10 & 3.01 & 3.01 & 3.18 \\ 20 & 3.40 & 3.40 & 4.08 \\ 30 & 4.32 & 4.32 & 4.49 \\ 40 & 4.76 & 4.76 & 5.17 \\ 50 & 5.02 & 5.02 & 5.17 \\ 60 & 5.41 & 5.41 & 5.86 \\ 70 & 6.15 & 6.15 & 5.94 \\ 80 & 6.15 & 6.15 & 6.27 \\ 90 & 6.66 & 6.66 & 6.35 \\ 100 & 6.66 & 6.66 & 6.55 \\ 110 & 6.54 & 6.54 & 6.07 \\ 120 & 6.06 & 6.06 & 5.41\end{array}$

$\begin{array}{lcccc}\text { Site 3, 2.5” } & \text { Ht }(\mathrm{mm}) & \text { Test } 1 & \text { Test } 2(\mathrm{~m} / \mathrm{s}) & \text { Test } 3(\mathrm{~m} / \mathrm{s}) \\ \text { Entrainment } & 5 & 1.57 & 2.22 & 1.99 \\ & 10 & 3.84 & 4.71 & 4.04 \\ & 20 & 5.57 & 5.88 & 5.58 \\ & 30 & 7.29 & 7.33 & 7.21 \\ & 40 & 8.95 & 9.24 & 8.70 \\ & 50 & 10.12 & 9.68 & 9.52 \\ & 60 & 10.24 & 10.06 & 9.77 \\ & 70 & 10.24 & 10.18 & 10.07 \\ & 80 & 10.36 & 10.25 & 10.32 \\ 90 & 10.28 & 10.18 & 10.39 \\ & 100 & 10.04 & 10.25 & 10.32 \\ & 110 & 9.87 & 9.93 & 10.15 \\ & 120 & 9.54 & 9.66 & 9.95\end{array}$




\begin{tabular}{|c|c|c|c|c|}
\hline Site 3, 4" & Ht $\frac{\text { (mm) }}{5}$ & $\begin{array}{c}\text { Test } 1(\mathrm{~m} / \mathrm{s}) \\
2.23\end{array}$ & $\begin{array}{c}\text { Test } 2(\mathrm{~m} / \mathrm{s}) \\
1.99\end{array}$ & $\begin{array}{c}\text { Test } 3(\mathrm{~m} / \mathrm{s}) \\
1.58\end{array}$ \\
\hline & 10 & 4.05 & 3.52 & 3.86 \\
\hline & 20 & 5.13 & 4.73 & 4.99 \\
\hline & 30 & 6.22 & 5.68 & 5.90 \\
\hline & 40 & 7.32 & 6.87 & 7.05 \\
\hline & 50 & 7.97 & 7.49 & 7.73 \\
\hline & 60 & 8.18 & 8.19 & 8.19 \\
\hline & 70 & 8.54 & 8.34 & 8.43 \\
\hline & 80 & 8.71 & 8.57 & 8.64 \\
\hline & 90 & 8.71 & 8.63 & 8.72 \\
\hline & 100 & 8.57 & 8.63 & 8.64 \\
\hline & 110 & 8.27 & 8.43 & 8.29 \\
\hline & 120 & 8.27 & 8.03 & 8.04 \\
\hline
\end{tabular}




\section{Joshua}

Site 1, 2"

Entrainment

Ht (mm)

5
10

20

30

40

50

60

70

80

90

100

110

120

Site 1, 3.5'

Ht 5

10

20

30

40

50

60

70

80

90

100

110

120

Site 2, 1.5"

Entrainment

Ht $(\mathrm{mm}) \quad$ Test $1(\mathrm{~m} / \mathrm{s})$

5.48

6.71

7.90

9.35

10.37

10.60

10.84

11.72

11.94

12.04

11.94

11.51

11.29

110

120

80

90

100
4.44

5.11

6.84

.52

8.93

68

8.82

8.82

.68

8.59

45
Test $2(\mathrm{~m} / \mathrm{s})$

4.95

5.98

7.44

8.13

8.99

9.59

10.02

10.50

10.84

10.84

10.68

10.33

10.26

Test $2(\mathrm{~m} / \mathrm{s})$

4.34

4.88

6.02

6.98

7.66

8.13

8.49

8.86

8.86

8.86

9.00

8.91

8.77

Test $2(\mathrm{~m} / \mathrm{s})$

\subsection{3}

7.59

9.23

9.88

10.13

10.37

11.19

11.94

11.94

12.15

12.05

11.84

11.63
Test $3(\mathrm{~m} / \mathrm{s})$

4.84

5.64

7.50

8.56

9.25

9.76

10.25

10.56

10.94

10.83

10.79

10.60

10.32

Test $3(\mathrm{~m} / \mathrm{s})$

4.46

5.14

6.11

7.06

7.83

8.35

8.50

8.79

9.01

9.01

8.93

8.64

8.44

Test $3(\mathrm{~m} / \mathrm{s})$

6.33

7.26

8.53

9.63

9.63

10.62

11.20

11.85

11.85

12.16

12.27

11.95

11.42 


\begin{tabular}{|c|c|c|c|c|}
\hline Site 2, 3" & $\frac{\mathrm{Ht}}{5}(\mathrm{~mm})$ & $\begin{array}{c}\text { Test } 1(\mathrm{~m} / \mathrm{s}) \\
5.26\end{array}$ & $\begin{array}{c}\text { Test } 2(\mathrm{~m} / \mathrm{s}) \\
5.15\end{array}$ & $\begin{array}{c}\text { Test } 3(\mathrm{~m} / \mathrm{s}) \\
5.16\end{array}$ \\
\hline & 10 & 6.06 & 5.48 & 5.71 \\
\hline & 20 & 7.26 & 7.08 & 7.01 \\
\hline & 30 & 7.76 & 7.52 & 7.85 \\
\hline & 40 & 8.23 & 7.91 & 8.23 \\
\hline & 50 & 8.62 & 9.09 & 8.90 \\
\hline & 60 & 9.05 & 9.17 & 9.58 \\
\hline & 70 & 9.51 & 9.44 & 9.96 \\
\hline & 80 & 9.77 & 9.96 & 9.84 \\
\hline & 90 & 9.90 & 9.96 & 9.50 \\
\hline & 100 & 9.90 & 10.49 & 9.76 \\
\hline & 110 & 9.85 & 9.96 & 9.58 \\
\hline & 120 & 9.38 & 9.36 & 9.23 \\
\hline
\end{tabular}

Site 3, 0.5'

Entrainment

Ht (mm)

Test $1(\mathrm{~m} / \mathrm{s})$

5
10

20

30

40

50

60

70

80

90

100

110

120

Site 3, 2"

Ht
5
10
20
30
40
50
60
70
80
90
100
110
120

Ht
5
10
20
30
40
50
60
70
80
90
100
110
120

2.24
4.20

5.93

8.54

9.11

10.99

11.97

12.59

13.64

14.62

15.05

14.96

14.54

Test $2(\mathrm{~m} / \mathrm{s})$

Test $3(\mathrm{~m} / \mathrm{s})$

2.77

4.50

6.36

4.23

8.11

9.55

10.43

11.47

13.02

13.59

14.76

5.98

7.83

9.18

10.48

12.27

12.58

13.56

15.01

14.38

14.84

14.73

14.99

14.23

14.29

$\mathrm{mm})$

Test $1(\mathrm{~m} / \mathrm{s}$ 2.26

3.57

4.79

6.58

7.81

8.59

Test $2(\mathrm{~m} / \mathrm{s})$

Test $3(\mathrm{~m} / \mathrm{s})$

\section{(}

30

9.30

10.34

11.39

11.83

12.04

2.25

3.56

2.26

3.57

4.78

4.79

6.57

7.64

8.58

6.77

7.66

9.29

8.60

11.03

9.97

10.71

11.37

11.48

11.40

12.02

11.95

11.92

12.05

12.04

11.59

11.73

11.83

11.29 


$\begin{array}{lccc}\begin{array}{l}\text { Altered Surfaces } \\ \text { RotoDry }\end{array} & & & \\ \text { Day 1 } & \text { Ht }(\mathrm{mm}) & \text { Test } 1(\mathrm{~m} / \mathrm{s}) & \text { Test } 2(\mathrm{~m} / \mathrm{s}) \\ \text { Entrainment } & 5 & 2.23 & 1.58 \\ & 10 & 2.54 & 2.73 \\ & 20 & 2.54 & 3.15 \\ & 30 & 2.73 & 3.15 \\ 40 & 3.15 & 3.52 \\ & 50 & 3.73 & 4.05 \\ & 60 & 4.46 & 3.86 \\ 70 & 4.05 & 3.38 \\ & 80 & 4.17 & 4.05 \\ & 90 & 4.17 & 3.86 \\ & 100 & 3.86 & 4.05 \\ 110 & 4.35 & 4.34 \\ 120 & 4.35 & 4.17\end{array}$

\section{Day 2}

$\begin{array}{cccc}\text { Ht }(\mathrm{mm}) & \text { Test } 1(\mathrm{~m} / \mathrm{s}) & \text { Test } 2(\mathrm{~m} / \mathrm{s}) & \text { Test } 3(\mathrm{~m} / \mathrm{s}) \\ 5 & 2.71 & 3.35 & 3.13 \\ 10 & 3.13 & 3.83 & 3.71 \\ 20 & 3.50 & 4.14 & 4.32 \\ 30 & 3.71 & 4.02 & 4.85 \\ 40 & 4.03 & 4.14 & 5.10 \\ 50 & 4.86 & 4.14 & 5.33 \\ 60 & 4.43 & 4.84 & 5.19 \\ 70 & 4.60 & 5.09 & 4.43 \\ 80 & 4.32 & 4.42 & 4.43 \\ 90 & 4.32 & 3.83 & 4.95 \\ 100 & 4.86 & 4.69 & 5.56 \\ 110 & 4.86 & 4.69 & 5.10 \\ 120 & 4.96 & 4.94 & 4.70\end{array}$

$\begin{array}{lcccc}\text { Week 1, 5.5" } & \mathrm{Ht}(\mathrm{mm}) & \text { Test } 1(\mathrm{~m} / \mathrm{s}) & \text { Test } 2(\mathrm{~m} / \mathrm{s}) & \text { Test } 3(\mathrm{~m} / \mathrm{s}) \\ \text { Entrainment } & 10 & 5.15 & 5.48 & 5.50 \\ & 20 & 6.33 & 6.52 & 6.35 \\ & 30 & 6.82 & 7.18 & 7.03 \\ & 40 & 7.25 & 7.35 & 7.44 \\ & 50 & 7.35 & 7.69 & 7.71 \\ & 60 & 7.35 & 7.75 & 7.61 \\ & 70 & 7.35 & 7.42 & 7.38 \\ & 80 & 7.35 & 7.42 & 7.38 \\ & 90 & 7.35 & 7.25 & 6.73 \\ & 100 & 7.35 & 7.25 & 6.47 \\ & 110 & 7.25 & 7.25 & 6.66 \\ & 120 & 7.08 & 7.00 & 6.66\end{array}$




\begin{tabular}{|c|c|c|c|c|}
\hline \multirow[t]{14}{*}{ Week 1, 7"' } & $\mathrm{Ht}(\mathrm{mm})$ & Test $1(\mathrm{~m} / \mathrm{s})$ & Test $2(\mathrm{~m} / \mathrm{s})$ & Test $3(\mathrm{~m} / \mathrm{s})$ \\
\hline & 5 & 4.49 & 4.49 & 4.50 \\
\hline & 10 & 5.17 & 4.92 & 5.03 \\
\hline & 20 & 5.94 & 5.41 & 5.73 \\
\hline & 30 & 6.15 & 5.86 & 6.16 \\
\hline & 40 & 6.66 & 6.15 & 6.28 \\
\hline & 50 & 6.66 & 6.27 & 5.86 \\
\hline & 60 & 6.47 & 6.35 & 5.95 \\
\hline & 70 & 5.94 & 6.15 & 5.95 \\
\hline & 80 & 5.72 & 6.27 & 6.07 \\
\hline & 90 & 5.02 & 6.27 & 6.07 \\
\hline & 100 & 5.02 & 6.07 & 5.95 \\
\hline & 110 & 5.17 & 6.07 & 5.73 \\
\hline & 120 & 5.17 & 5.64 & 5.73 \\
\hline \multicolumn{5}{|l|}{ RotoFoam } \\
\hline \multirow[t]{13}{*}{ Day 1} & $\underset{5}{\mathrm{Ht}(\mathrm{mm})}$ & $\begin{array}{c}\text { Test } 1(\mathrm{~m} / \mathrm{s}) \\
3.86\end{array}$ & $\begin{array}{c}\text { Test } 2(\mathrm{~m} / \mathrm{s}) \\
3.73\end{array}$ & \\
\hline & 10 & 4.34 & 4.45 & \\
\hline & 20 & 4.88 & 4.88 & \\
\hline & 30 & 4.72 & 5.13 & \\
\hline & 40 & 4.88 & 5.59 & \\
\hline & 50 & 5.45 & 5.59 & \\
\hline & 60 & 5.72 & 5.45 & \\
\hline & 70 & 5.89 & 5.45 & \\
\hline & 80 & 5.89 & 5.36 & \\
\hline & 90 & 5.59 & 4.98 & \\
\hline & 100 & 4.72 & 4.72 & \\
\hline & 110 & 4.98 & 4.62 & \\
\hline & 120 & 4.45 & 4.88 & \\
\hline \multirow[t]{14}{*}{ Day 2} & $\mathrm{Ht}(\mathrm{mm})$ & Test $1(\mathrm{~m} / \mathrm{s})$ & Test $2(\mathrm{~m} / \mathrm{s})$ & Test $3(\mathrm{~m} / \mathrm{s})$ \\
\hline & 5 & 2.70 & 2.96 & 2.70 \\
\hline & 10 & 2.70 & 3.49 & 3.35 \\
\hline & 20 & 3.81 & 3.69 & 4.01 \\
\hline & 30 & 4.29 & 4.41 & 4.30 \\
\hline & 40 & 4.82 & 4.83 & 4.13 \\
\hline & 50 & 4.92 & 5.08 & 4.01 \\
\hline & 60 & 5.07 & 5.17 & 4.57 \\
\hline & 70 & 5.07 & 4.57 & 4.41 \\
\hline & 80 & 4.57 & 4.93 & 4.30 \\
\hline & 90 & 4.92 & 4.68 & 4.30 \\
\hline & 100 & 4.67 & 4.41 & 3.69 \\
\hline & 110 & 4.40 & 4.41 & 3.69 \\
\hline & 120 & 4.12 & 4.30 & 3.82 \\
\hline
\end{tabular}




\begin{tabular}{|c|c|c|c|c|}
\hline Week 1, 5.5" & $\mathrm{Ht}(\mathrm{mm})$ & Test $1(\mathrm{~m} / \mathrm{s})$ & Test $2(\mathrm{~m} / \mathrm{s})$ & $\begin{array}{c}\text { Test } 3(\mathrm{~m} / \mathrm{s}) \\
486\end{array}$ \\
\hline Entrainment & $\begin{array}{r}5 \\
10\end{array}$ & $\begin{array}{l}4.30 \\
458\end{array}$ & $\begin{array}{l}4.84 \\
518\end{array}$ & $\begin{array}{l}4.86 \\
5.11\end{array}$ \\
\hline & 20 & $\begin{array}{l}4.00 \\
5.32\end{array}$ & $\begin{array}{l}5.18 \\
5.84\end{array}$ & $\begin{array}{l}J .11 \\
5.65\end{array}$ \\
\hline & 30 & 6.05 & 6.24 & 6.07 \\
\hline & 40 & 6.36 & 6.62 & 6.58 \\
\hline & 50 & 6.55 & 6.80 & 6.84 \\
\hline & 60 & 7.08 & 7.08 & 6.94 \\
\hline & 70 & 6.98 & 7.15 & 7.36 \\
\hline & 80 & 6.98 & 7.15 & 7.19 \\
\hline & 90 & 7.15 & 7.15 & 7.12 \\
\hline & 100 & 7.15 & 7.15 & 7.29 \\
\hline & 110 & 6.91 & 6.98 & 7.19 \\
\hline & 120 & 6.91 & 6.62 & 7.01 \\
\hline Week 1, 7'" & $\mathrm{Ht} \underset{5}{(\mathrm{~mm})}$ & $\begin{array}{c}\text { Test } 1(\mathrm{~m} / \mathrm{s}) \\
4.13\end{array}$ & $\begin{array}{c}\text { Test } 2(\mathrm{~m} / \mathrm{s}) \\
4.05\end{array}$ & $\begin{array}{c}\text { Test } 3(\mathrm{~m} / \mathrm{s}) \\
4.35\end{array}$ \\
\hline & 10 & 4.41 & 4.17 & 4.73 \\
\hline & 20 & 4.94 & 4.73 & 5.13 \\
\hline & 30 & 5.32 & 4.99 & 5.46 \\
\hline & 40 & 5.54 & 5.23 & 5.69 \\
\hline & 50 & 5.76 & 5.46 & 6.03 \\
\hline & 60 & 5.84 & 5.90 & 6.03 \\
\hline & 70 & 5.96 & 5.90 & 6.31 \\
\hline & 80 & 5.96 & 5.90 & 6.31 \\
\hline & 90 & 5.84 & 6.03 & 6.23 \\
\hline & 100 & 5.84 & 6.23 & 6.11 \\
\hline & 110 & 5.84 & 5.90 & 6.11 \\
\hline & 120 & 5.63 & 5.82 & 6.03 \\
\hline
\end{tabular}




\begin{tabular}{|c|c|c|c|c|}
\hline \multirow[t]{13}{*}{ Tire Control 3" } & $\mathrm{Ht} \underset{5}{(\mathrm{~mm})}$ & $\begin{array}{c}\text { Test } 1(\mathrm{~m} / \mathrm{s}) \\
6.12\end{array}$ & $\begin{array}{c}\text { Test } 2(\mathrm{~m} / \mathrm{s}) \\
5.70\end{array}$ & $\begin{array}{c}\text { Test } 3(\mathrm{~m} / \mathrm{s}) \\
5.60\end{array}$ \\
\hline & 10 & 7.06 & 6.70 & 6.43 \\
\hline & 20 & 8.59 & 7.83 & 7.56 \\
\hline & 30 & 9.16 & 8.65 & 8.58 \\
\hline & 40 & 9.74 & 9.42 & 9.28 \\
\hline & 50 & 9.94 & 9.81 & 9.97 \\
\hline & 60 & 10.11 & 10.11 & 9.85 \\
\hline & 70 & 10.67 & 10.24 & 9.92 \\
\hline & 80 & 10.43 & 10.36 & 9.80 \\
\hline & 90 & 9.61 & 10.43 & 9.72 \\
\hline & 100 & 9.56 & 9.74 & 9.72 \\
\hline & 110 & 9.56 & 9.48 & 9.46 \\
\hline & 120 & 9.29 & 9.21 & 9.20 \\
\hline \multirow[t]{13}{*}{ Tire Control 6" } & Ht $\frac{(\mathrm{mm})}{5}$ & $\begin{array}{l}\text { Test } 1(\mathrm{~m} / \mathrm{s}) \\
4.05\end{array}$ & $\begin{array}{c}\text { Test } 2(\mathrm{~m} / \mathrm{s}) \\
4.07\end{array}$ & Test $3(\mathrm{~m} / \mathrm{s})$ \\
\hline & 10 & 4.46 & 4.37 & 4.48 \\
\hline & 20 & 5.14 & 4.91 & 5.26 \\
\hline & 30 & 5.38 & 5.49 & 5.63 \\
\hline & 40 & 5.91 & 6.06 & 5.63 \\
\hline & 50 & 6.31 & 6.26 & 5.63 \\
\hline & 60 & 6.81 & 6.14 & 6.26 \\
\hline & 70 & 6.70 & 6.46 & 6.65 \\
\hline & 80 & 6.70 & 6.26 & 6.65 \\
\hline & 90 & 6.62 & 5.84 & 6.46 \\
\hline & 100 & 6.43 & 6.34 & 6.46 \\
\hline & 110 & 6.03 & 6.46 & 6.06 \\
\hline & 120 & 5.82 & 5.84 & 5.93 \\
\hline
\end{tabular}


Tire Tracks

Site 1, 7.5'

Entrainment

$\begin{array}{cccc}\text { Ht }(\mathrm{mm}) & \text { Test } 1(\mathrm{~m} / \mathrm{s}) & \text { Test } 2(\mathrm{~m} / \mathrm{s}) & \text { Test } 3(\mathrm{~m} / \mathrm{s}) \\ 5 & 3.85 & 3.51 & 3.52 \\ 10 & 4.16 & 3.84 & 3.85 \\ 20 & 4.33 & 4.15 & 4.04 \\ 30 & 4.16 & 4.15 & 4.16 \\ 40 & 4.61 & 4.60 & 4.61 \\ 50 & 4.97 & 4.86 & 4.97 \\ 60 & 5.12 & 4.86 & 5.35 \\ 70 & 5.45 & 5.35 & 5.58 \\ 80 & 5.58 & 5.79 & 5.67 \\ 90 & 5.67 & 5.57 & 5.67 \\ 100 & 5.67 & 5.57 & 5.58 \\ 110 & 5.45 & 5.21 & 5.58 \\ 120 & 5.12 & 5.11 & 5.35\end{array}$

Site 1, 8.25" Ht $(\mathrm{mm}) \quad$ Test $1(\mathrm{~m} / \mathrm{s}) \quad$ Test $2(\mathrm{~m} / \mathrm{s}) \quad$ Test $3(\mathrm{~m} / \mathrm{s})$

$\begin{array}{rlll}5 & 3.37 & 3.15 & 3.53 \\ 10 & 3.85 & 3.73 & 3.87 \\ 20 & 4.34 & 4.05 & 4.18 \\ 30 & 4.45 & 4.05 & 4.35 \\ 40 & 4.61 & 4.34 & 4.63 \\ 50 & 4.98 & 4.46 & 4.63 \\ 60 & 4.98 & 4.73 & 5.23 \\ 70 & 4.98 & 5.23 & 5.23 \\ 80 & 4.61 & 5.37 & 5.23 \\ 90 & 4.98 & 5.37 & 5.23 \\ 100 & 4.98 & 5.23 & 5.23 \\ 110 & 4.98 & 5.13 & 5.14 \\ 120 & 4.61 & 4.73 & 4.89\end{array}$

Site 1, 9"

$\begin{array}{cccc}\text { Ht }(\mathrm{mm}) & \text { Test } 1(\mathrm{~m} / \mathrm{s}) & \text { Test } 2(\mathrm{~m} / \mathrm{s}) & \text { Test } 3(\mathrm{~m} / \mathrm{s}) \\ 5 & 3.18 & 3.16 & 3.17 \\ 10 & 3.55 & 3.74 & 3.54 \\ 20 & 3.55 & 4.06 & 3.75 \\ 30 & 3.76 & 4.35 & 3.88 \\ 40 & 4.08 & 4.18 & 4.07 \\ 50 & 4.20 & 4.35 & 4.37 \\ 60 & 4.49 & 4.63 & 4.75 \\ 70 & 4.77 & 4.74 & 4.91 \\ 80 & 4.92 & 4.74 & 4.91 \\ 90 & 4.77 & 4.74 & 4.91 \\ 100 & 4.77 & 4.47 & 4.75 \\ 110 & 4.77 & 4.47 & 4.75 \\ 120 & 4.66 & 4.63 & 4.37\end{array}$




$\begin{array}{lcccc}\text { Site 2, 7.5" } & \text { Ht }(\mathrm{mm}) & \text { Test } 1(\mathrm{~m} / \mathrm{s}) & \text { Test } 2(\mathrm{~m} / \mathrm{s}) & \text { Test } 3(\mathrm{~m} / \mathrm{s}) \\ \text { Entrainment } & 5 & 2.53 & 2.97 & 2.98 \\ & 10 & 3.13 & 3.71 & 3.37 \\ & 20 & 3.84 & 4.03 & 4.15 \\ & 30 & 4.03 & 4.60 & 4.44 \\ & 40 & 4.43 & 4.70 & 4.60 \\ & 50 & 4.86 & 4.86 & 4.86 \\ & 60 & 4.86 & 4.86 & 5.11 \\ & 70 & 4.96 & 5.34 & 5.11 \\ & 80 & 4.86 & 5.43 & 5.21 \\ & 90 & 4.86 & 5.34 & 5.21 \\ & 100 & 5.10 & 5.10 & 5.21 \\ & 110 & 4.96 & 4.86 & 5.11 \\ & 120 & 4.96 & 4.70 & 4.86 \\ & & & \\ & & & & \\ & \text { Ht }(\mathrm{mm}) & \text { Test } 1(\mathrm{~m} / \mathrm{s}) & \text { Test } 2(\mathrm{~m} / \mathrm{s}) & \text { Test } 3(\mathrm{~m} / \mathrm{s}) \\ & 5 & 2.22 & 2.23 & 2.73 \\ & 10 & 2.53 & 2.54 & 3.15 \\ & 20 & 3.14 & 3.15 & 3.86 \\ & 30 & 3.52 & 3.15 & 4.05 \\ & 40 & 3.85 & 3.38 & 4.17 \\ & 50 & 3.85 & 3.86 & 4.46 \\ & 60 & 3.85 & 4.17 & 4.62 \\ & 70 & 4.16 & 4.17 & 4.62 \\ 80 & 3.85 & 4.17 & 4.62 \\ 90 & 3.85 & 4.17 & 4.46 \\ & 100 & 4.04 & 4.34 & 4.35 \\ & 110 & 4.04 & 4.34 & 4.35 \\ & 40 & 4.04 & 4.34 & 4.35 \\ & & & & \end{array}$




\section{APPENDIX 4}

WIND TUNNEL PROFILE PARAMETER DATA 


\section{Wind Tunnel Results}

NOTE: Results are presented only for those data with $z_{o}$ errors of $10 \%$ or less.

Measurement in inches after site is bypass valve opening

\section{Natural Surfaces}

\section{Area 6}

Site 1, 3" Movement

$\mathrm{U}^{*}(\mathrm{~m} / \mathrm{s})$

$\mathrm{z}_{\mathrm{O}}(\mathrm{m})$

$\mathrm{U}^{*}$ Error (\%)

$\mathrm{z}_{\mathrm{o}}$ Error $(\%)$

Run 1
0.97
0.0019
0.01
0.02

Run 2
0.97
0.0012
0.01
0.02

Run 3
1.00
0.0014
0.01
0.01

Mean

0.98

0.0015

0.01

0.01

Site 1, 6"

$\mathrm{U}^{*}(\mathrm{~m} / \mathrm{s})$

$\mathrm{z}_{\mathrm{o}}(\mathrm{m})$

0.72

0.62

0.72

0.69

0.0010

0.0005

0.01

0.01

0.0009

0.0008

U* Error (\%)

0.76

2.20

0.01

0.01

$\mathrm{z}_{\mathrm{o}}$ Error (\%)

Site 2, 2"

$\mathrm{U}^{*}(\mathrm{~m} / \mathrm{s})$

$\mathrm{z}_{\mathrm{o}}(\mathrm{m})$

U* Error (\%)

$\mathrm{z}_{\mathrm{o}}$ Error (\%)

0.94
0.0007
0.01
0.01

0.83
0.0004
0.01
0.03

0.89

0.89

$0.0001 \quad 0.0004$

0.02

0.01

0.02

0.02

Site 2, 6"

$\mathrm{U}^{*}(\mathrm{~m} / \mathrm{s})$

$\begin{array}{llrl}0.69 & 0.65 & 0.67 & \\ 0.0017 & 0.0013 & \text { Data } & 0.0015 \\ 0.01 & 0.01 & \text { Voided } & 0.01 \\ 2.54 & 2.85 & 2.70 & \end{array}$

$\mathrm{z}_{\mathrm{o}}(\mathrm{m})$

U* Error (\%)

$\mathrm{z}_{\mathrm{o}}$ Error (\%)

2.54

2.85

2.70

Site 3, 2"

$\mathrm{U}^{*}(\mathrm{~m} / \mathrm{s})$

$\mathrm{z}_{\mathrm{O}}(\mathrm{m})$

$\mathrm{U}^{*}$ Error (\%)

$\mathrm{z}_{\mathrm{o}}$ Error (\%)

$\begin{array}{llll}1.03 & 1.07 & 1.00 & 1.03 \\ 0.0012 & 0.0015 & 0.0010 & 0.0012 \\ 0.01 & 0.02 & 0.02 & 0.02 \\ 0.01 & 0.01 & 0.01 & 0.01\end{array}$

Site 3, 6"

$\mathrm{U}^{*}(\mathrm{~m} / \mathrm{s})$

\begin{tabular}{|c|c|c|c|c|}
\hline & & & $\begin{array}{l}\text { Run } 4 \\
0.75\end{array}$ & $\begin{array}{l}\text { Mean } \\
0.75\end{array}$ \\
\hline Data & Data & Data & 0.0026 & 0.0026 \\
\hline Voided & Voided & Voided & 0 & 0 \\
\hline & & & 3.96 & 3.96 \\
\hline
\end{tabular}




\section{Bedrock}

Site 1, 2.25" Movement Run 1

$\mathrm{U}^{*}(\mathrm{~m} / \mathrm{s})$

$\mathrm{z}_{\mathrm{o}}(\mathrm{m})$

1.27

0.0030

Run 2
1.29
0.0028
0.02
0.00

Run 3

Mean

$\mathrm{U}^{*}$ Error (\%)

$\mathrm{z}_{\mathrm{o}}$ Error (\%)

0.03

0.00

1.33

1.30

0.0033

0.0030

0.03

0.03

0.00

0.00

Site 1, 4"

$\mathrm{U}^{*}(\mathrm{~m} / \mathrm{s})$

$\mathrm{z}_{\mathrm{o}}(\mathrm{m})$

0.94

1.03

1.01

1.00

$\mathrm{U}^{*}$ Error (\%)

0.0023

0.0031

0.0030

0.0028

0.04

0.06

0.03

0.04

$\mathrm{z}_{\mathrm{o}}$ Error (\%)

0.26

0.19

0.18

0.21

Site 2, 2.5"

$\mathrm{U}^{*}(\mathrm{~m} / \mathrm{s})$

$\mathrm{z}_{\mathrm{o}}(\mathrm{m})$

$\mathrm{U}^{*}$ Error (\%)

$\mathrm{z}_{\mathrm{o}}$ Error (\%)

$\begin{array}{llll}0.97 & 0.98 & 1.03 & 0.99 \\ 0.0009 & 0.0009 & 0.0010 & 0.0009 \\ 0.03 & 0.01 & 0.00 & 0.01 \\ 0.02 & 0.01 & 0.01 & 0.01\end{array}$

Site 2, 6"

$\mathrm{U}^{*}(\mathrm{~m} / \mathrm{s})$

$\mathrm{z}_{\mathrm{o}}(\mathrm{m})$

U* Error (\%)

$\mathrm{z}_{\mathrm{o}}$ Error (\%)

$\begin{array}{llrl}0.63 & 0.58 & & 0.60 \\ 0.0013 & 0.0009 & \text { Data } & 0.0011 \\ 0.03 & 0.04 & \text { Voided } & 0.03 \\ 4.04 & 4.87 & & 4.45\end{array}$

Site 3, 2"

$\mathrm{U}^{*}(\mathrm{~m} / \mathrm{s})$

$\mathrm{z}_{\mathrm{o}}(\mathrm{m})$

$\mathrm{U}^{*}$ Error (\%)

$\mathrm{z}_{\mathrm{o}}$ Error (\%)

$\begin{array}{llll}0.91 & 0.91 & 1.07 & 0.96 \\ 0.0007 & 0.0008 & 0.0013 & 0.0009 \\ 0.00 & 0.03 & 0.03 & 0.02 \\ 0.03 & 0.04 & 0.01 & 0.03\end{array}$

Site 3, 2.5"

$\mathrm{U}^{*}(\mathrm{~m} / \mathrm{s})$

$\mathrm{z}_{\mathrm{O}}(\mathrm{m})$

U* Error (\%)

$\mathrm{z}_{\mathrm{o}}$ Error (\%)

$\begin{array}{llrl}0.97 & 0.98 & & 0.97 \\ 0.0009 & 0.0009 & \text { Data } & 0.0009 \\ 0.03 & 0.01 & \text { Voided } & 0.02 \\ 0.02 & 0.01 & & 0.02\end{array}$

Site 3, 6"

$\mathrm{U}^{*}(\mathrm{~m} / \mathrm{s})$

$\mathrm{z}_{\mathrm{o}}(\mathrm{m})$

Data

U* Error (\%)

Voided

0.98

0.78

0.88

0.0051

0.0029

0.0040

$\mathrm{z}_{\mathrm{o}}$ Error (\%)

0.00

0.02

0.01

0.56

1.82

1.19 


\section{Gate}

Site 1, 2.5" Movement

$\mathrm{U}^{*}(\mathrm{~m} / \mathrm{s})$

$\mathrm{z}_{\mathrm{o}}(\mathrm{m})$

U* Error (\%)

$\mathrm{z}_{\mathrm{o}}$ Error (\%)

$\begin{array}{llll}\text { Run } & \text { Run 2 } & \text { Run 3 } & \text { Mean } \\ 0.89 & 0.96 & 0.80 & 0.88 \\ 0.0012 & 0.0017 & 0.0008 & 0.0012 \\ 0.09 & 0.08 & 0.14 & 0.10 \\ 0.11 & 0.07 & 0.25 & 0.14\end{array}$

Site 1, 6"

$\mathrm{U}^{*}(\mathrm{~m} / \mathrm{s})$

$\mathrm{z}_{\mathrm{o}}(\mathrm{m})$

$\mathrm{U}^{*}$ Error (\%)

$\mathrm{z}_{\mathrm{o}}$ Error $(\%)$

1.62

1.20

0.80

1.21

0.0254

0.0145

0.0656

0.0155

0.01

0.03

0.02

0.02

0.03

0.15

1.89

0.69

Site 2, 1.5"

$\mathrm{U}^{*}(\mathrm{~m} / \mathrm{s})$ Entrainment

1.11

1.03

1.07

$\mathrm{z}_{\mathrm{o}}(\mathrm{m})$

0.0009 Data

$\mathrm{U}^{*}$ Error (\%)

$0.02 \quad$ Voided

0.0008

0.0009

0.00

0.01

0.01

$\mathrm{z}_{\mathrm{o}}$ Error $(\%)$

Site 2, 3"

$\mathrm{U}^{*}(\mathrm{~m} / \mathrm{s})$

$\mathrm{z}_{\mathrm{o}}(\mathrm{m})$

$\mathrm{U}^{*}$ Error (\%)

$\mathrm{z}_{\mathrm{o}}$ Error (\%)

$\begin{array}{llll}0.93 & 0.95 & 1.07 & 0.98 \\ 0.0013 & 0.0015 & 0.0023 & 0.0017 \\ 0.09 & 0.09 & 0.05 & 0.08 \\ 0.16 & 0.16 & 0.07 & 0.13\end{array}$

Site 2, 6"

$\mathrm{U}^{*}(\mathrm{~m} / \mathrm{s})$

0.72

0.72

0.60

0.68

$\mathrm{z}_{\mathrm{o}}(\mathrm{m})$

0.0026

0.0026

0.0014

0.0022

$\mathrm{U}^{*}$ Error (\%)

0.06

0.06

0.02

0.04

3.38

3.38

4.66

3.81

Site 3, 2.5"

$\mathrm{U}^{*}(\mathrm{~m} / \mathrm{s})$ Entrainment

1.45

1.26

1.33

1.35

$\mathrm{z}_{\mathrm{O}}(\mathrm{m})$

0.0038

0.0026

0.0032

0.0032

0.04

0.05

0.02

0.04

0.00

0.00

0.00

0.00

\section{Site 3, 4"}

$\mathrm{U}^{*}(\mathrm{~m} / \mathrm{s})$

$\mathrm{z}_{\mathrm{o}}(\mathrm{m})$

0.98

1.06

1.01

1.02

U* Error (\%)

0.0022

0.0031

0.0025

0.02

0.0026

0.02

0.02

0.11

0.02

0.11

0.09

0.11 
Joshua

Site 1, 2" Movement

$\mathrm{U}^{*}(\mathrm{~m} / \mathrm{s})$ Entrainment

$\mathrm{z}_{\mathrm{o}}(\mathrm{m})$

$\mathrm{U}^{*}$ Error $(\%)$

$\mathrm{z}_{\mathrm{o}}$ Error (\%)

$\begin{array}{llll}\text { Run 1 } & \text { Run 2 } & \text { Run 3 } & \text { Mean } \\ 1.13 & 0.95 & 1.01 & 1.03 \\ 0.0015 & 0.0009 & 0.0010 & 0.0011 \\ 0.02 & 0.01 & 0.00 & 0.01 \\ 0.00 & 0.02 & 0.01 & 0.01\end{array}$

Site 1, 3.5"

$\mathrm{U}^{*}(\mathrm{~m} / \mathrm{s})$

$\mathrm{z}_{\mathrm{o}}(\mathrm{m})$

$\mathrm{U}^{*}$ Error (\%)

$\mathrm{z}_{\mathrm{o}}$ Error $(\%)$

0.76

0.0008

0.82

0.79

0.79

0.01

0.0010

0.0008

0.0008

0.38

0.01

0.01

0.01

0.23

0.26

0.29

Site 2, 1.5"

$\mathrm{U}^{*}(\mathrm{~m} / \mathrm{s})$ Entrainment

$\mathrm{z}_{\mathrm{o}}(\mathrm{m})$

1.04

0.85

0.94

0.94

U* Error (\%)

zo Error (\%)

0.0008

0.0003

0.0005

0.0005

0.02

0.03

0.03

0.02

0.00

0.02

0.01

0.01

Site 2, 3"

$\mathrm{U}^{*}(\mathrm{~m} / \mathrm{s})$

$\mathrm{z}_{\mathrm{o}}(\mathrm{m})$

0.69

0.84

0.88

0.80

U* Error (\%)

zo Error (\%)

0.0003

0.0008

0.0008

0.0006

0.01

0.03

0.02

0.02

0.42

0.15

0.09

0.22

Site 3,0.5"

$\mathrm{U}^{*}(\mathrm{~m} / \mathrm{s})$ Entrainment

2.02

0.0055

1.83

1.93

1.93

$\mathrm{z}_{\mathrm{o}}(\mathrm{m})$

0.03

0.0046

0.0052

0.0051

$\mathrm{U}^{*}$ Error $(\%)$

0.03

0.04

0.03

zo Error (\%)

0.00

0.00

0.00

0.00

Site 3, 2"

$\mathrm{U}^{*}(\mathrm{~m} / \mathrm{s})$

$\mathrm{z}_{\mathrm{o}}(\mathrm{m})$

1.63

1.65

1.66

1.65

U* Error (\%)

0.0055

0.0056

0.0055

0.0055

$\mathrm{z}_{\mathrm{o}}$ Error (\%)

0.00

0.04

0.03

0.03

0.00

0.00

0.00 
Disturbed Surfaces

Roto Dry

Day 1 Movement

$\mathrm{U}^{*}(\mathrm{~m} / \mathrm{s})$ Entrainment

Run 1

Run 2

Run 3

Mean

$\mathrm{z}_{\mathrm{O}}(\mathrm{m})$

1.03

0.0111

0.72

0.87

U* Error (\%)

0.05

0.0053

No Run 3

0.0082

$\mathrm{z}_{\mathrm{o}}$ Error (\%)

3.19

0.03

0.04

8.32

5.76

\section{Day 2}

Week 1, 5.5"

$\mathrm{U}^{*}(\mathrm{~m} / \mathrm{s})$ Entrainment

$\mathrm{z}_{\mathrm{O}}(\mathrm{m})$

$\mathrm{U}^{*}$ Error (\%)

$\mathrm{z}_{\mathrm{O}}$ Error (\%)

Week 1, 7'

\section{Roto Foam}

Day 1

DataVoided

\section{Day 2}

$\mathrm{U}^{*}(\mathrm{~m} / \mathrm{s})$

$\mathrm{z}_{\mathrm{o}}(\mathrm{m})$

U* Error (\%)

$\mathrm{z}_{\mathrm{o}}$ Error (\%)

Week 1, 5.5"

$\mathrm{U}^{*}(\mathrm{~m} / \mathrm{s})$ Entrainment

$\mathrm{z}_{\mathrm{o}}(\mathrm{m})$

$\mathrm{U}^{*}$ Error (\%)

$\mathrm{z}_{\mathrm{o}}$ Error (\%)

Week 1, 7'

\section{Tire Control 3"}

$\mathrm{U}^{*}(\mathrm{~m} / \mathrm{s})$

$\mathrm{z}_{\mathrm{o}}(\mathrm{m})$

U* Error (\%)

$\mathrm{z}_{\mathrm{O}}$ Error (\%)

Tire Control 6"

$\mathrm{U}^{*}(\mathrm{~m} / \mathrm{s})$

$\mathrm{z}_{\mathrm{O}}(\mathrm{m})$

U* Error (\%)

$\mathrm{z}_{\mathrm{O}}$ Error (\%)
Data Voided

$\begin{array}{llll}0.57 & 0.55 & 0.56 & 0.56 \\ 0.0003 & 0.0002 & 0.0002 & 0.0002 \\ 0.02 & 0.01 & 0.00 & 0.01 \\ 2.51 & 2.38 & 2.19 & 2.36\end{array}$

Data Voided

No Run 3

$\begin{array}{llrl}0.60 & 0.62 & & 0.61 \\ 0.0017 & 0.0018 & \text { Data } & 0.0017 \\ 0.00 & 0.01 & \text { Voided } & 0.01 \\ 9.61 & 6.35 & & 7.98\end{array}$

$\begin{array}{llll}0.55 & 0.42 & 0.50 & 0.49 \\ 0.0004 & 0.0001 & 0.0002 & 0.0002 \\ 0.02 & 0.00 & 0.02 & 0.01 \\ 3.89 & 7.04 & 4.13 & 5.02\end{array}$

DataVoided

$\begin{array}{llll}0.71 & 0.77 & 0.81 & 0.76 \\ 0.0002 & 0.0003 & 0.0004 & 0.0003 \\ 0.01 & 0.01 & 0.03 & 0.02 \\ 0.15 & 0.10 & 0.10 & 0.12\end{array}$

$\begin{array}{llrl}0.82 & 0.62 & & 0.72 \\ 0.0022 & 0.0008 & \text { Data } & 0.0010 \\ 0.01 & 0.01 & \text { Voided } & 0.01 \\ 0.72 & 3.10 & & 1.91\end{array}$


Tire Tracks

Site 1, 7.5"

$\mathrm{U}^{*}(\mathrm{~m} / \mathrm{s})$ Entrainment

0.59

$\begin{array}{ll}0.65 & 0.62\end{array}$

$\mathrm{z}_{\mathrm{o}}(\mathrm{m})$

0.0018 Data

$0.0023 \quad 0.0014$

$\mathrm{U}^{*}$ Error (\%)

$0.01 \quad$ Voided

0.01

0.01

$\mathrm{z}_{\mathrm{o}}$ Error (\%)

5.70

3.84

4.77

Site 1, 7.5”

Data Voided

Site 1, 9"

Data Voided

Site 2, 7.5" Entrainment Data Voided

Site 2, 9"

Data Voided 


\section{DISTRIBUTION}

\section{Desert Research Institute}

Roger Jacobson

Desert Research Institute

Water Resources Center

P.O. Box 19040

Las Vegas, NV 89132-0040

Marjory Jones

Desert Research Institute

Water Resources Center

P.O. Box 60220

Reno, NV 89506-0220

\section{International Technology Corp.}

Rick Waddell

Geotrans, c/o IT

4330 Valley View

Suite 112, MS-439

Las Vegas, NV 89103

Joe Yeasted

International Technology Corporation

4330 S. Valley View

Suite 114

Las Vegas, NV 89103

\section{Lawrence Livermore National Laboratory}

Lee Davisson

Nuclear Chemistry Division

Lawrence Livermore National Laboratory

P.O. Box 808

$\mathrm{L}-237$

Livermore, CA 94550

Greg Nimz

Earth Sciences Division

Lawrence Livermore National Laboratory

P.O. Box 808, MS L207

Livermore, CA 94550

\section{Los Alamos National Laboratory}

Joe Thompson

Los Alamos National Laboratory

INC-11, MS J514

P.O. Box 1663

Los Alamos, NM 87545

\section{Raytheon Services Nevada}

Stuart E. Rawlinson

Raytheon Services Nevada

P.O. Box 95487, M/S 580

Las Vegas, NV 89193-5487

\section{Reynolds Electrical \& Engineering Co.}

Martha DeMarre

Chief, Document Research Section

Health Protection Dept.

Reynolds Electrical \& Engineering Co.

P.O. Box 98521

Las Vegas, NV 89193-8521

Brian Dozier

Reynolds Electrical \& Engineering Co.

2501 Wyandotte

Mercury, NV 89102

\section{State of Nevada}

Larry Franks

Nevada State Health Department

Radiological Health Section

620 Belrose Avenue

Las Vegas, NV 89158

\section{U.S. Department of Defense}

David Bedsun

Defense Nuclear Agency

Field Command

Nevada Operations Office

P.O. Box 208

Mercury, NV 89023-0208 


\section{U.S. Department of Energy}

Bob Bangerter

Environmental Restoration Division

Nevada Operations Office

U.S. Department of Energy

P.O. Box 98518

Las Vegas, NV 89193-8518

Joanne M. Bradbery, Director

Contracts Division

Nevada Operations Office

U.S. Department of Energy

P.O. Box 98518

Las Vegas, NV 89193-8518

Frank Di Sanza, Director

Project Control and Technology

Development Division

Nevada Operations Office

U.S. Department of Energy

P.O. Box 98518

Las Vegas, NV 89193-8518

Doug Duncan

Hydrology Program Manager

Office of Environmental Restoration and Waste Management

Nevada Operations Office

U.S. Department of Energy

P.O. Box 98518

Las Vegas, NV 89193-8518

Donald Elle, Director

Environmental Protection Division

Nevada Operations Office

U.S. Department of Energy

P.O. Box 98518

Las Vegas, NV 89193-8518

Joseph N. Fiore, Acting Assistant Manager

Office of Environmental Restoration

and Waste Management

Nevada Operations Office

U.S. Department of Energy

P.O. Box 98518

Las Vegas, NV 89193-8518
Joseph M. Ginanni

Waste Management Division

Nevada Operations Office

U.S. Department of Energy

P.O. Box 98518

Las Vegas, NV 89193-8518

Steve Lawrence

Environmental Restoration Division

Nevada Operations Office

U.S. Department of Energy

P.O. Box 98518

Las Vegas, NV 89193-8518

John Ledbetter

Contracts Division

Nevada Operations Office

U.S. Department of Energy

P.O. Box 98518

Las Vegas, NV 89193-8518

Steve Leedom

Test Operations Division

Nevada Operations Office

U.S. Department of Energy

P.O. Box 98518

Las Vegas, NV 89193-8518

Charles E. McWilliam, Director

Operations Management Division

Nevada Operations Office

U.S. Department of Energy

P.O. Box 98518

Las Vegas, NV 89193-8518

Steve Mellington, Director

Environmental Restoration Division

Nevada Operations Office

U.S. Department of Energy

P.O. Box 98518

Las Vegas, NV 89193-8518

Beth Moore

Waste Management Division

Nevada Operations Office

U.S. Department of Energy

P.O. Box 98518

Las Vegas, NV 89193-8518 
Richard Pearl

Environmental Protection Division

Nevada Operations Office

U.S. Department of Energy

P.O. Box 98518

Las Vegas, NV 89193-8518

Monica Salazar-Sanchez

Environmental Restoration Division

Nevada Operations Office

U.S. Department of Energy

P.O. Box 98518

Las Vegas, NV 89193-8518

Ralph Smiecinski

Project Control and Test Development Division Nevada Operations Office

U.S. Department of Energy

P.O. Box 98518

Las Vegas, NV 89193-8518

\section{U.S. Geological Survey}

Virginia Glanzman

U.S. Geological Survey

Box 2506, MS 913

Denver Federal Center

Denver, CO 80225

Randy Laczniak

U.S. Geological Survey

Water Resources Division

6770 S. Paradise Rd.

Las Vegas, NV 89119

Paul Orkild

U.S. Geological Survey

Box 2506, MS 913

Denver Federal Center

Denver, CO 80225

Doug Trudeau

U.S. Geological Survey

Water Resources Division

6770 S. Paradise Rd.

Las Vegas, NV 89119

\section{LIBRARIES}

Annie Kelley

State Documents Department

Nevada State Library

Capitol Complex

Carson City, NV 89710

Archives

Getchell Library

University of Nevada, Reno

Beverly Carter

MacKay School of Mines Library

University of Nevada, Reno

Document Section, Library

University of Nevada, Las Vegas

4505 Maryland Parkway

Las Vegas, NV 89154

Library (Stead)

Desert Research Institute

P.O. Box 60220

Reno, Nevada 89506-0220

Library

IT Corporation

4330 S. Valley View

Suite 114

Las Vegas, NV 89103

ATTN: Toni Miller

Library

Southern Nevada Science Center

Desert Research Institute

P.O. Box 19040

Las Vegas, NV 89132-0040

Technical Information Resource Center

Nevada Operations Office

U.S. Department of Energy

P.O. Box 98518

Las Vegas, NV 89193-8518

Librarian

Water Resources Center Archives

410 O`Brien Hall

University of California

Berkeley, CA 94720-1718 